\title{
Comparación de las surgencias de la Guajira colombiana y del oriente venezolano
}

\section{Comparison of the upwellings of the Colombian Guajira and eastern Venezuela}

\author{
Alfredo Gómez Gaspar ${ }^{1 *}$ y Arturo Acero $P^{2}$ \\ (iD) $0000-0002-2430-2738$ (D) $0000-0002-6637-9901$ \\ 1. Universidad de Oriente y Museo Marino de Margarita, Boca de Río, Venezuela.agomezgaspar@yahoo.com \\ 2. Instituto para el Estudio de las Ciencias del Mar (Cecimar), Universidad Nacional de Colombia sede Caribe, Playa Salguero, Santa Marta, Colombia. \\ aacerop@unal.edu.co \\ * Autor de correspondencia.
}

\section{RESUMEN}

$\mathrm{E}$ n el Caribe sur se presentan dos áreas principales de surgencia, la Guajira colombiana y el oriente de Venezuela; sin embargo, la producción pesquera es muy desigual, a pesar de que en la Guajira la intensidad del viento es mayor y teóricamente la surgencia es más intensa. Por esta razón, debería tener una producción pesquera mayor que la venezolana, lo que no ocurre. Se plantean las posibles causas de esta notable diferencia y se comentan aspectos relacionados con el viento, la hidrografía, la concentración de nutrientes, la biomasa del fitoplancton, la plataforma continental, el aporte de ríos, la presencia de islas y otros factores. El oriente de Venezuela tiene mayor fertilidad y producción pesquera porque la masa de Agua Subsuperficial Subtropical es la que abastece la surgencia durante los primeros meses del año (sequía). En el segundo semestre, cuando la surgencia se relaja, el área se enriquece con materia orgánica del río Orinoco y el aporte de biomasa fitoplanctónica proveniente de lagunas costeras, golfos y bahías semicerradas. También juega un papel fundamental la amplitud de la plataforma continental con la presencia de archipiélagos, islas mayores y menores que causan enriquecimientos locales y la concentración y retención del plancton. Esto último aumenta la productividad biológica y propicia la reproducción de esos organismos. En la Guajira, la surgencia podría estar influenciada por la contracorriente del Darién, que por su origen debe contener baja concentración de nutrientes inorgánicos; además, en esta zona no están presentes grandes ríos que aporten materia orgánica y la plataforma continental es poco amplia y no contiene islas que propicien el aumento de la productividad acuática. Para la comprensión de la surgencia en la Guajira, se sugieren estudios para el seguimiento in situ de la hidrografía, nutrientes inorgánicos, clorofila y la abundancia de fito y zooplancton.

PALABRAS CLAVE: surgencia tropical, Guajira colombiana, Oriente venezolano, Caribe sur, ecología

\section{ABSTRACT}

I $\mathrm{n}$ the southern Caribbean, there are two main upwelling areas, the Colombian Guajira and eastern Venezuela. However, fishing production is highly dissimilar, even though in the Guajira the wind intensity is stronger and theoretically the upwelling is more intense. For this reason, it should have a higher fishing production than Venezuela, which is not the case. The possible reasons for this important difference are presented, detailing aspects related to wind, hydrography, nutrient concentration, phytoplankton biomass, continental shelf, river contribution, island presence and other factors. Eastern Venezuela has greater fertility and fishing production because the Subtropical Subsuperficial Water mass is what supplies the water upwelling during the first months of the year (dry season). In the second semester, when the upwelling relaxes, the area is enriched with organic matter from the Orinoco River and the contribution of phytoplankton biomass from coastal lagoons, inlets, and partially closed bays. The wide extension of the continental shelf, with the presence of archipelagos, large islands, and islets that cause local enrichment and the plankton concentration and retention also plays a fundamental role. The latter increases biological productivity and support plankton reproduction. On the other hand, Colombian Guajira upwelling water may be influenced by the Darien Countercurrent, which, by its origin, should be poor in inorganic nutrients; furthermore, this region lacks important rivers that contribute organic matter and the Guajira continental shelf is rather narrow and does not contain islands that may help to increase aquatic productivity. In order to understand Guajira upwelling it is necessary to follow its hydrography in situ, as well as inorganic nutrients, chlorophyll, and phytoplankton and zooplankton abundances.

KEYWORDS: Tropical upwelling, Colombian Guajira, eastern Venezuela, Southern Caribbean, ecology

DOI: https://doi.org/10.25268/bimc.invemar.2020.49.2.943 


\section{INTRODUCCIÓN}

Los primeros estudios oceanográficos del mar Caribe se hicieron en la década de 1920 (Nielsen, 1925; Jacobsen, 1929). La circulación general, las masas de agua y su origen fueron estudiados entre 1933-1934 (Parr, 1937), mencionando una posible ocurrencia de surgencia en el sureste del Caribe. Años después, se estudió su estratificación y movimiento (Wüst, 1963, 1964; Gordon, 1967). En 1958, observaciones hidrográficas próximas a la costa norte de Suramérica indicaron que en el oriente de Venezuela la temperatura en superficie era menor que en el norte y centro del Caribe. Esta fue la evidencia inicial de surgencia de aguas (Richards, 1960) y, además, con base en la salinidad y el oxígeno disuelto en secciones desde la costa hasta $13^{\circ}$ $\mathrm{N}$ y desde $62^{\circ}$ a $69^{\circ} \mathrm{W}$. Pocos años después, se verificó la presencia de surgencia en la Guajira de Colombia (Gordon, 1967; Perlroth, 1971; Corredor, 1977; Fajardo, 1979), donde se han realizado varios trabajos basados en mediciones indirectas y datos in situ de cruceros que han tomado en consideración la temperatura y la salinidad (Andrade y Barton, 2005; Paramo et al., 2011; Bastidas-Salamanca et al., 2017; Murcia-Riaño et al., 2017).

Las condiciones hidrográficas y químicas del Caribe venezolano fueron discutidas por Richards (1960) y la influencia o distribución de las aguas del río Orinoco por Gade (1961). La relación entre surgencia y viento con las corrientes y la topografía del fondo fue estudiada por Fukuoka $(1962,1963,1965 a)$ y la relación entre masas de agua y los ríos Amazonas y Orinoco por Ljoen y Herrera (1965), quienes determinaron el transporte hacia el norte del agua superficial, por el ascenso de aguas profundas al norte de isla Margarita. La surgencia máxima ocurre $\sim 90 \mathrm{~km}$ de la costa donde se forma una divergencia (Gordon, 1967). La menor temperatura costera es causada por la surgencia relacionada con el viento (Fukuoka et al., 1963; Fukuoka, 1964) y también por una contracorriente hacia el oriente, desde la costa hasta $\sim 13^{\circ} \mathrm{N}$ y $63^{\circ}$ a $64^{\circ} \mathrm{W}$, facilitada por la topografía del fondo (Fukuoka, 1965b). En la dirección oriente-occidente, la surgencia abarca el estado Sucre, con las penínsulas de Paria y Araya, y el estado Nueva Esparta (islas Margarita, Coche, Cubagua) hasta cercanías de la isla La Tortuga $\left(61^{\circ} 50^{\prime}-65^{\circ} 25^{\prime} \mathrm{W}\right)$ y la cubeta occidental de la fosa de Cariaco, donde la surgencia tiene menor intensidad (Okuda et al., 1974).

Según Okuda (1978, 1981), en el oriente de Venezuela se identifican tres masas de agua: las

\section{INTRODUCTION}

The first oceanographic studies of the Caribbean Sea were made in the 1920s (Nielsen, 1925; Jacobsen, 1929). The general circulation, the water masses, and their origin were studied between 1933-1934 (Parr, 1937), mentioning a possible occurrence of upwelling in the southeast of the Caribbean. Years later, its stratification and movement were studied (Wüst, 1963, 1964; Gordon, 1967). In 1958, hydrographic observations near the north coast of South America indicated that in eastern Venezuela the surface temperature was lower than in the north and center of the Caribbean. This was the initial evidence of water upwelling (Richards, 1960) and based on salinity and dissolved oxygen in sections from the coast to $13{ }^{\circ} \mathrm{N}$ and from $62^{\circ}$ to $69^{\circ} \mathrm{W}$. A few years later, the presence of upwelling was verified in the Guajira of Colombia (Gordon, 1967; Perlroth, 1971; Corredor, 1977; Fajardo, 1979), where several studies have been carried out based on indirect measurements and in situ data from cruise ships that have taken into consideration temperature and salinity (Andrade and Barton, 2005; Paramo et al., 2011; Bastidas-Salamanca et al., 2017; Murcia-Riaño et al., 2017).

The hydrographic and chemical conditions of the Venezuelan Caribbean were discussed by Richards (1960) and the influence or distribution of the waters of the Orinoco River by Gade (1961). The relationship between upwelling and wind with currents and bottom topography was studied by Fukuoka (1962, 1963, 1965a) and the relationship between water masses and the Amazon and Orinoco rivers by Ljoen and Herrera (1965), who determined the transport towards the north of the surface water, by the ascent of deep waters to the north of Margarita Island. The maximum upwelling occurs $\sim 90 \mathrm{~km}$ from the coast where divergence forms (Gordon, 1967). The lower coastal temperature is caused by upwelling related to the wind (Fukuoka et al., 1963; Fukuoka, 1964) and also by a countercurrent to the east, from the coast to $\sim 13{ }^{\circ} \mathrm{N}$ and 63 to $64^{\circ} \mathrm{W}$, facilitated by bottom topography (Fukuoka, 1965b). In the east-west direction, the upwelling covers the state of Sucre, with the peninsulas of Paria and Araya, and the state of Nueva Esparta (Margarita, Coche, Cubagua islands) to the vicinity of La Tortuga Island $\left(61^{\circ} 50^{\prime}-65^{\circ} 25^{\prime} \mathrm{W}\right)$ and the western basin of the Cariaco fossa, where the upwelling is less intense (Okuda et al., 1974).

According to Okuda $(1978,1981)$, in eastern Venezuela three water masses are identified: Surface 
Superficiales (temperatura: $>24{ }^{\circ} \mathrm{C}$; salinidad: $<36,7$ ), las Subtropicales (temperatura: 21 a $24{ }^{\circ} \mathrm{C}$; salinidad: > 36,7) y las Subsuperficiales (temperatura: $<21^{\circ} \mathrm{C}$; salinidad: 36,7 ). Si los vientos tienen una velocidad de $>6 \mathrm{~m} / \mathrm{s}$, causan una surgencia intensa (Herrera y Febres, 1975) y afloran Aguas Subsuperficiales. Mientras tanto, los vientos moderados hacen subir Aguas Subtropicales (Okuda, 1981). Las aguas suben desde profundidades entre 90 y $175 \mathrm{~m}$ y se notan hasta $150 \mathrm{~km}$ fuera de la costa (Herrera y Febres, 1975); la termoclina se encuentra entre 16 y 26 m (Margalef, 1969). También se menciona que, a mediados de año, ocurre otra surgencia de menor intensidad en esta región (Rueda-Roa et al., 2018).

En el siglo pasado, a partir de la década de 1970, el oriente venezolano se ha investigado desde los puntos de vista geológico, físico, químico y biológico, siendo quizás la región marina más conocida del Caribe. Por lo menos hasta 2015 se efectuaron proyectos multidisciplinarios por encargo de la industria petrolera (Liñero-Arana et al., 2009). Desde 1995 hasta 2017, en la fosa de Cariaco (cubeta oriental) se muestreó una estación $\left(10,50^{\circ} \mathrm{N}, 64,66^{\circ} \mathrm{W}\right)$ denominada Cariaco para estudiar procesos biogeoquímicos y ecológicos (Müller-Karger et al., 2019). Esta serie de tiempo, por su duración, ha sido única en el Caribe.

El ascenso de aguas profundas que llegan a la superficie (afloran) es surgencia en sentido estricto, lo que puede considerarse como sinónimo de productividad acuática elevada; se trata de aguas ricas en nutrientes inorgánicos que utilizan las microalgas que aumentan rápidamente su biomasa y propician así una mayor proliferación de productores secundarios y gran abundancia de recursos pesqueros utilizables por otros organismos acuáticos y por el hombre que los captura. Las principales surgencias del Caribe sur ocurren en dos áreas (Figura 1): al oriente de Venezuela (63$\left.65^{\circ} \mathrm{W}\right)$ y al occidente $\left(70-73^{\circ} \mathrm{W}\right)$ en la Guajira colombiana (Rueda-Roa, 2012). También se ha identificado surgencia entre Santa Marta y el Parque Nacional Natural Tayrona (Paramo et al., 2011; Murcia-Riaño et al., 2017).

Estudios de evaluación pesquera en el Caribe sur, financiados por la Comunidad Económica Europea (R/V Nansen) y realizados en 1988, estimaron una biomasa de 1580000 toneladas ( $t$ ) de peces pequeños pelágicos, principalmente sardina, además de anchoas, carángidos, escómbridos y barracudas (Stromme y Saetersdal, 1989). $78 \%$ está presente en el oriente de Venezuela y $18 \%$ en la Guajira de Colombia (Rueda-Roa, 2012). Sin embargo, en Venezuela las cifras de captura reales de sardina son muy (temperature: $>24{ }^{\circ} \mathrm{C}$; salinity: < 36.7), Subtropical (temperature: 21 to $24{ }^{\circ} \mathrm{C}$; salinity: > 36.7) and Subsurface (temperature: $<21{ }^{\circ} \mathrm{C}$; salinity: 36.7 ). If the winds have a speed of $>6 \mathrm{~m} / \mathrm{s}$, they cause an intense upwelling (Herrera and Febres, 1975) and Subsurface Waters emerge. Meanwhile, moderate winds raise Subtropical Waters (Okuda, 1981). The waters rise from depths between 90 and $175 \mathrm{~m}$ and are noticeable up to $150 \mathrm{~km}$ off the coast (Herrera and Febres, 1975); the thermocline is between 16 and $26 \mathrm{~m}$ (Margalef, 1969). It is also mentioned that, in the middle of the year, another upwelling of less intensity occurred in this region (Rueda-Roa et al., 2018).

In the last century, since the 1970s, eastern Venezuela has been investigated from a geological, physical, chemical, and biological point of view is perhaps the best known marine region in the Caribbean. Until at least 2015, multidisciplinary projects were carried out commissioned by the oil industry (Liñero-Arana et al., 2009). In the Cariaco Trench (eastern basin), from 1995 to 2017 -a period that, due to its duration, has been unique in the Caribbean- a station $\left(10.50{ }^{\circ} \mathrm{N}, 64.66{ }^{\circ} \mathrm{W}\right)$ called Cariaco was sampled to study biogeochemical and ecological processes (MüllerKarger et al., 2019).

The rise of deep waters that reach the surface is upwelling in the strict sense, which can be considered synonymous with high aquatic productivity; it is about waters rich in inorganic nutrients that use microalgae that rapidly increase their biomass and thus favor a greater proliferation of secondary producers and a great abundance of fishery resources usable by other aquatic organisms and by the man who catches them. The main upwellings of the southern Caribbean occur in two areas (Figure 1): east of Venezuela $\left(63-65^{\circ} \mathrm{W}\right)$ and west $\left(70-73^{\circ} \mathrm{W}\right)$ in the Colombian Guajira (Rueda-Roa, 2012). Upwelling has also been identified between Santa Marta and the Tayrona National Natural Park (Paramo et al., 2011; Murcia-Riaño et al., 2017).

Fisheries assessment studies in the southern Caribbean, financed by the European Economic Community (R/V Nansen) and carried out in 1988, estimated biomass of 1580000 tonnes ( $\mathrm{t}$ ) of small pelagic fish, mainly sardines, in addition to anchovies, carangids, scombrids, and barracudas (Stromme and Saetersdal, 1989). $78 \%$ is present in eastern Venezuela and $18 \%$ in Guajira de Colombia (Rueda-Roa, 2012). However, in Venezuela, the actual sardine catch figures are much lower because the maximum official production is $200232 \mathrm{t}$ per year (Gómez et al., 2008, 2014; 


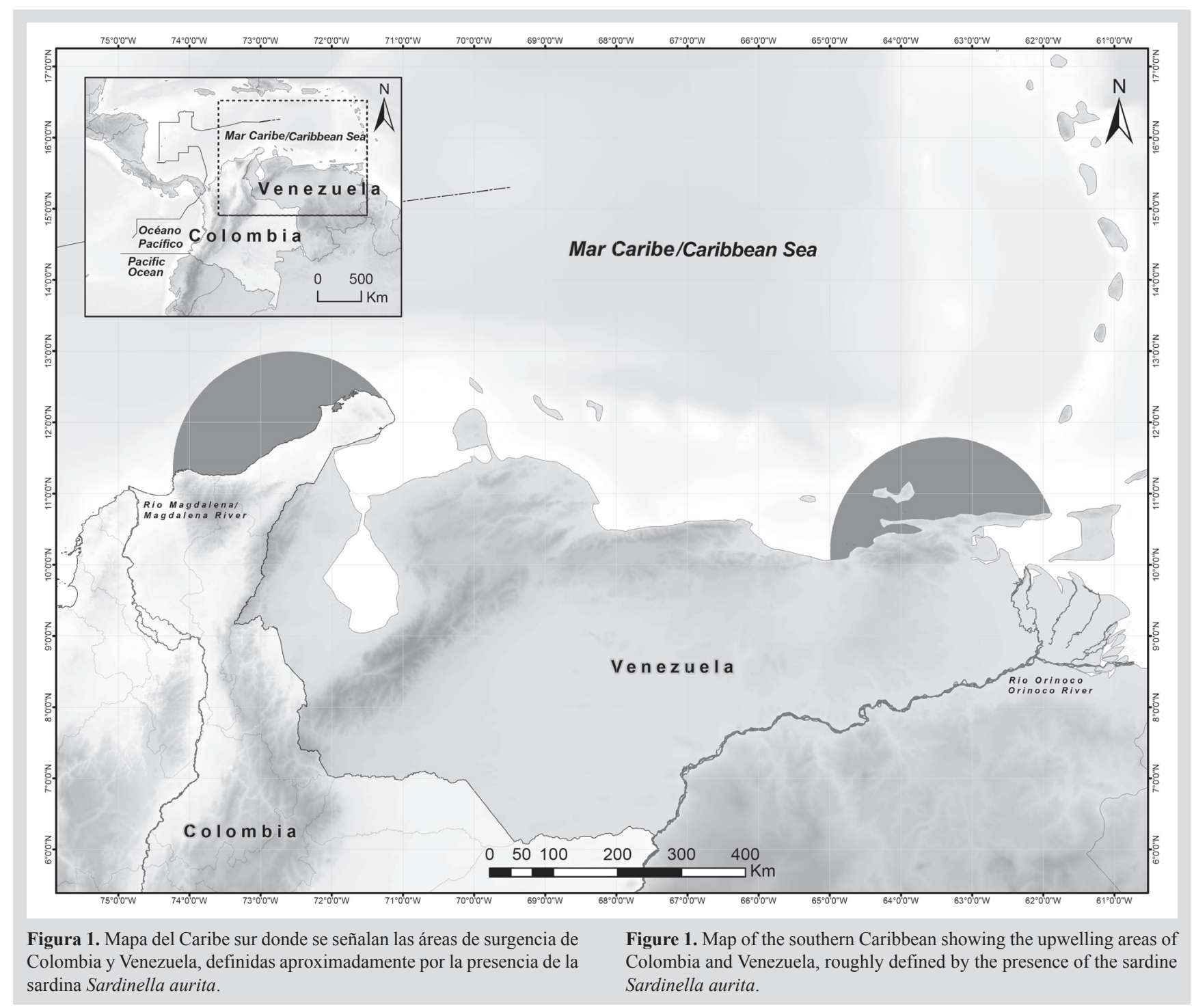

inferiores porque la producción oficial máxima es de 200232 t anuales (Gómez et al., 2008, 2014; Mendoza, 2015; RuedaRoa et al., 2017). En 2005 inició la crisis sardinera: disminuyó $50 \%$ la pesca nacional y más de $90 \%$ en isla de Margarita. Durante aproximadamente una década las capturas fueron inferiores a 50000 t. Se ha verificado que la crisis puede ser la consecuencia de un cambio de régimen ecológico, por surgencias poco intensas (Gómez, 2018a, 2019).

En Colombia, aunque existe limitada información pesquera en el área de surgencia, en 1988 se estimó la presencia de $100000 \mathrm{t}$ de pequeños pelágicos en la Guajira (Stromme y Saetersdal, 1989) y en 1997 evaluaciones estimaron $15680 \mathrm{t}$ (Paramo y Viaña, 2002). En esta región, la oceanografía local es modulada por la intensidad de la surgencia estacional y su dinámica puede influenciar la distribución y abundancia de los recursos (Paramo et al., 2003).
Mendoza, 2015; Rueda-Roa et al., 2017). In 2005, the sardine crisis began: national fishing decreased by $50 \%$ and more than $90 \%$ on the island of Margarita. For about a decade the catches were less than 50000 t. It has been verified that the crisis may be the consequence of a change in the ecological regime, due to low-intensity upwellings (Gómez, 2018a, 2019).

In Colombia, although there is limited fishing information in the upwelling area, in 1988 the presence of $100000 \mathrm{t}$ of small pelagic fish was estimated in La Guajira (Stromme and Saetersdal, 1989) and in 1997 evaluations estimated $15680 \mathrm{t}$ (Paramo and Viaña, 2002). In this region, the local oceanography is modulated by the intensity of the seasonal upwelling and its dynamics can influence the distribution and abundance of the resources (Paramo et al., 2003). 
En Venezuela, la producción pesquera nacional ha oscilado entre $250000 \mathrm{y}>500000 \mathrm{t}$ a comienzos del presente siglo. En 2010 disminuyó a 167600 t (Mendoza, 2015) por la crisis sardinera que inició en 2005 (Gómez, 2018a, 2019). En la región nororiental se captura más de $60 \%$ de la producción nacional y del mar Caribe (Gómez, 1996, 2001). En Colombia, las cifras de la pesca en el Caribe alcanzaron 22000 t en 2014 y 23500 t en 2018, de las cuales la Guajira aportó menos de 400 t por la pesca artesanal (Carlos J. Polo, com. pers.). En el oriente de Venezuela, modelos tróficos estiman una biomasa de $122 \mathrm{t} / \mathrm{km}^{2} /$ año (Mendoza, 2003); en la Guajira, de 68 t/km²/año (Criales-Hernández et al., 2006).

Como se puede observar, en las dos surgencias costeras la producción pesquera es muy desigual. Esta revisión plantea y discute las causas probables de dicha desigualdad, a pesar de que este fenómeno tiene su causa principal en los vientos alisios del noreste que afectan ambos países. En comparación con el oriente venezolano, durante el período 1998-2009 la velocidad del viento en la Guajira fue 1,3 veces más fuerte (Rueda-Roa, 2012) y teóricamente es más intensa la surgencia de aguas. Por ello, debería ser mayor la abundancia de peces como la sardina o relacionados y, en general, debería haber una producción pesquera mayor que en Venezuela, pero esto no ocurre. Se ha planteado que en el Caribe sur el Agua Subtropical alimenta las surgencias, razón por la cual se asume que en focos con temperatura similar debe existir igual contenido de nutrientes (Rueda-Roa, 2012), como fue planteado hace décadas (Corredor, 1977, 1979). No obstante, esa no parece ser la realidad. Se mencionan aspectos relacionados con el viento, la hidrografía de aguas surgentes, la concentración de nutrientes, la biomasa del fitoplancton, la importancia de la plataforma continental, el aporte de ríos y la presencia de islas, entre otros factores. Además, se comentan los índices de surgencia e hipótesis de la intensificación de surgencias por el calentamiento global.

De ambas surgencias, pero especialmente de la colombiana, desde finales del siglo XX se han publicado numerosos artículos que utilizan datos obtenidos mediante tecnología satelital, los cuales tienen mayor cobertura espacial y periodicidad y son óptimos para estudios dinámicos. Sin embargo, los complejos procesos de interacción atmósferasuperficie oceánica hacen que los datos geofísicos del color del océano obtenidos desde el espacio produzcan gran incertidumbre; los resultados son una aproximación y deben validarse con observaciones de campo (Bastidas-Salamanca et al., 2017).
In Venezuela, national fish production has fluctuated between 250000 and $>500000 \mathrm{t}$ at the beginning of this century. In 2010 it decreased to $167600 \mathrm{t}$ (Mendoza, 2015 ) due to the sardine crisis that began in 2005 (Gómez, 2018a, 2019). In the northeastern region, more than $60 \%$ of the national production and the Caribbean Sea are captured (Gómez, 1996, 2001). In Colombia, fishing figures in the Caribbean reached $22000 \mathrm{t}$ in 2014 and $23500 \mathrm{t}$ in 2018, of which the Guajira contributed less than $400 \mathrm{t}$ from artisanal fishing (Carlos J. Polo, pers. comm.). In eastern Venezuela, trophic models estimate a biomass of $122 \mathrm{t} / \mathrm{km}^{2} /$ year (Mendoza, 2003); in La Guajira, $68 \mathrm{t} / \mathrm{km}^{2} /$ year (CrialesHernández et al., 2006).

As can be seen, in the two coastal upwellings, fishing production is very unequal. This review raises and discusses the probable causes of this inequality, although this phenomenon has its main cause in the northeast trade winds that affect both countries. Compared with eastern Venezuela, during the 1998-2009 period, the wind speed in La Guajira was 1.3 times stronger (Rueda-Roa, 2012) and the upwelling of waters is theoretically more intense. Therefore, the abundance of fish such as sardines or related should be greater and, in general, there should be a higher fish production than in Venezuela, but this does not happen. It has been proposed that in the southern Caribbean Subtropical Water feeds upwelling, which is why it is assumed that in foci with similar temperatures there must be the same nutrient content (Rueda-Roa, 2012) as was proposed decades ago (Corredor, 1977, 1979). However, that does not seem to be the reality. Aspects related to the wind, the hydrography of emerging waters, the concentration of nutrients, the biomass of the phytoplankton, the importance of the continental shelf, the contribution of rivers, and the presence of islands, among other factors, are mentioned. Also, the upwelling indices and hypotheses of upwelling intensification due to global warming, inclusive, are discussed.

From both sources, but especially from the Colombian one, since the end of the 20th century, numerous articles have been published that use data obtained through satellite technology, which have greater spatial coverage and periodicity and are optimal for dynamic studies. However, the complex processes of oceanic atmospheresurface interaction make geophysical data on ocean color obtained from space produce great uncertainty; The results are an approximation and must be validated with field observations (Bastidas-Salamanca et al., 2017). 
En la Guajira confluyen varios procesos oceanográficos. Es una región influenciada por la corriente del Caribe y el giro ciclónico Panamá-Colombia que afecta la zona por medio de la contracorriente del Darién, también denominada de Colombia (Andrade, 2001). El área se ha caracterizado mediante imágenes satelitales, que asocian la temperatura superficial con la concentración de clorofila (Bernal et al., 2010; Ruiz-Ochoa, 2011; Sarmiento-Devia et al., 2013; Alonso et al., 2015; Gutiérrez-Leones et al., 2015; Santos et al., 2016; Bastidas-Salamanca et al., 2017; Beier et al., 2017; Dueñas-Lagos et al., 2017; Murcia-Riaño et al., 2017; Montoya et al., 2018; Del Rosario et al., 2019; Correa-Ramírez et al., 2020, entre otros).

\section{VIENTOS}

La meteorología del Caribe puede describirse en términos del viento y de las lluvias, así como de la variabilidad espacio-temporal determinada por cambios de la presión atmosférica en la zona de convergencia intertropical (ZCIT) de los alisios, un cinturón de baja presión cerca del Ecuador que controla los regímenes de precipitación y vientos (Andrade y Barton, 2013). En la estación seca (diciembre a junio) o de viento, la ZCIT está en una posición más ecuatorial $\left(0-5^{\circ} \mathrm{S}\right)$ y los alisios del norte dominan el área. Desde julio, la ZCIT se mueve a una posición latitudinal más septentrional, hasta $10-12^{\circ} \mathrm{N}$, propiciando las precipitaciones (Aparicio, 2003).

Guajira de Colombia. Durante 1987-1988, se caracterizó el campo de vientos en el Caribe central con datos satelitales. Cerca de la costa, se presentan valores máximos de $>9 \mathrm{~m} / \mathrm{s}$. También se habla de periodicidad anual de vientos (época seca) de diciembre-marzo, de otro período con viento ligeramente fuerte (julio-agosto) y de la estación de lluvias (septiembre-noviembre) con viento débil (Andrade, 1993). La mayor parte del año el viento se dirige hacia el occidente, pero, cuando es más fuerte (diciembre-marzo) la dirección cambia hacia el suroccidente, paralelo a la costa; la máxima velocidad se presenta hacia $15^{\circ} \mathrm{N}$ (Andrade y Barton, 2005). La dirección del viento se alinea con la costa y la plataforma, lo cual conlleva al transporte de Ekman fuera de la costa y la surgencia de Aguas Subsuperficiales en la zona costera (Andrade et al., 2003; Andrade y Barton, 2005; Lonin et al., 2010). La intensidad del viento es mayor que en otras surgencias del mundo: 7,2 m/s en Benguela; $7,8 \mathrm{~m} / \mathrm{s}$ en California; $6,8 \mathrm{~m} / \mathrm{s}$ en NW de África; $5,7 \mathrm{~m} / \mathrm{s}$ en Perú y $9,5 \mathrm{~m} / \mathrm{s}$ en la Guajira (Chávez y Messié, 2009). Lo anterior sugiere que la Guajira es el sistema de borde occidental que
Several oceanographic processes converge in $\mathrm{La}$ Guajira. It is a region influenced by the Caribbean current and the Panama-Colombia cyclonic turn that affects the area through the Darien Countercurrent, also known as Colombia (Andrade, 2001). The area has been characterized by satellite images, which associate surface temperature with chlorophyll concentration (Bernal et al., 2010; RuizOchoa, 2011; Sarmiento-Devia et al., 2013; Alonso et al., 2015; Gutiérrez -Leones et al., 2015; Santos et al., 2016; Bastidas-Salamanca et al., 2017; Beier et al., 2017; DueñasLagos et al., 2017; Murcia-Riaño et al., 2017; Montoya et al., 2018; Del Rosario et al., 2019; Correa-Ramírez et al., 2020, among others).

\section{WINDS}

The meteorology of the Caribbean can be described in terms of wind and rainfall, as well as the space-time variability determined by changes in atmospheric pressure in the intertropical convergence zone (ITCZ) of the trade winds, a low-pressure belt near Ecuador that controls the regimes of precipitation and winds (Andrade and Barton, 2013). In the dry season (December to June) or windy, the ITCZ is in a more equatorial position $\left(0-5^{\circ} \mathrm{S}\right)$ and the northern trade winds dominate the area. Since July, the ITCZ moves to a more northern latitudinal position, up to $10-12{ }^{\circ} \mathrm{N}$, and encourages rainfall (Aparicio, 2003).

Colombian Guajira. During 1987-1988, the wind field in the central Caribbean was characterized by satellite data. Near the coast, maximum values of $>9 \mathrm{~m} / \mathrm{s}$ occur. There is also information about the annual periodicity of winds (dry season) from December-March, another period with slightly strong wind (July-August), and the rainy season (September-November) with the weak wind (Andrade, 1993). Most of the year, the wind is directed towards the west, but, when it is strongest (December-March), the direction changes towards the southwest, parallel to the coast; the maximum velocity appears towards $15{ }^{\circ} \mathrm{N}$ (Andrade and Barton, 2005). The wind direction is aligned with the coast and the sheld, which leads to Ekman transport off the coast and the upwelling of Subsurface Waters in the coastal zone (Andrade et al., 2003; Andrade and Barton, 2005; Lonin et al., 2010). The intensity of the wind is greater than in other upwellings in the world: $7.2 \mathrm{~m} / \mathrm{s}$ in Benguela; $7.8 \mathrm{~m} / \mathrm{s}$ in California; $6.8 \mathrm{~m} / \mathrm{s}$ in NW Africa; $5.7 \mathrm{~m} / \mathrm{s}$ in Peru and 9.5 $\mathrm{m} / \mathrm{s}$ in La Guajira (Chávez and Messié, 2009). The above suggests that the Guajira is the western edge system that 
podría producir el mayor volumen de surgencia por unidad de área en el mundo (Paramo et al., 2011).

Entre 1992-1999, se estudió la dinámica de la atmósfera y el océano con mediciones in situ y sensores remotos (Andrade y Barton, 2013). Se demostró la presencia de una celda atmosférica zonal $(2000 \mathrm{~km}$ en extensión oriente/occidente) compuesta por los alisios del noreste, que toman forma de un viento de chorro a nivel superficial. La posición de la celda propicia que en la costa continental se presente vegetación exuberante y áreas desérticas en distancias relativamente cortas. Durante la estación seca, los alisios tienen una velocidad diaria de entre 8 y $15 \mathrm{~m} / \mathrm{s}$ con un componente sur; en abril-junio, los vientos se debilitan siendo la "estación de transición"-; durante julio-agosto, los vientos se intensifican de nuevo - este período es llamado "veranillo"- En el periodo de lluvias (agosto-octubre), la ZCIT se mueve hacia el norte y permite que los alisios del sur (vientos $\sim 4 \mathrm{~m} / \mathrm{s}$ ) atraviesen América Central y alcancen la cuenca de Colombia, donde interactúan con los alisios del noreste y ocasionan una inestabilidad atmosférica que puede propiciar la formación de ciclones tropicales en el Caribe. Entre diciembre-marzo, el viento de chorro alcanza una velocidad de $\sim 12 \mathrm{~m} / \mathrm{s}$ con dirección al occidente, pero con un componente sur; en mayo, el viento disminuye $(<8 \mathrm{~m} / \mathrm{s})$ y en julio (veranillo) aumenta a $>9 \mathrm{~m} / \mathrm{s}$. Los vientos más débiles aparecen en octubre durante las lluvias (Andrade y Barton, 2013).

En el periodo $1999-2008$, entre $69^{\circ}-74^{\circ} \mathrm{W}$ ocurrieron vientos fuertes todo el año ( $>6 \mathrm{~m} / \mathrm{s})$; los máximos en juniojulio $(>9 \mathrm{~m} / \mathrm{s})$ y los mínimos $(6-7 \mathrm{~m} / \mathrm{s})$ en septiembreoctubre. Los vientos más fuertes se presentaron entre $74-76^{\circ}$ $\mathrm{W}$, con máximos en diciembre-abril (> $11 \mathrm{~m} / \mathrm{s})$, un máximo secundario en julio $(>9 \mathrm{~m} / \mathrm{s})$ y mínimos durante septiembreoctubre ( $\sim 5 \mathrm{~m} / \mathrm{s})$. Se menciona que, en el occidente del Caribe sur, el viento promedio fue de $8,23 \mathrm{~m} / \mathrm{s}$ (Rueda-Roa, 2012; Rueda-Roa y Müller-Karger, 2013). Durante 1999-2009, el bombeo Ekman fue positivo cerca de la costa, el transporte hacia el norte y noroccidente y la magnitud máxima al oriente de la cuenca Colombia (Pareja et al., 2013). La morfología matemática de la surgencia indica su conducción por la ZCIT. Su relación con el componente oriente-occidente de los vientos alisios tiene un desfase de cuatro meses. También se relaciona con la oscilación del sur (Alonso et al., 2015).

Recientes estudios indican que, en los meses de vientos intensos, el movimiento ascendente de aguas es completo y claro en superficie. Durante la temporada de lluvias, el ascenso puede ser parcial, sin que afloren las could produce the highest upwelling volume per unit area in the world (Paramo et al., 2011).

Between 1992-1999, the dynamics of the atmosphere and the ocean were studied with in situ measurements and remote sensing (Andrade and Barton, 2013). The presence of a zonal atmospheric cell (2000 $\mathrm{km}$ in east/west extension) made up of the northeast trade winds, which take the form of a jet wind at the surface level, was demonstrated. The position of the cell favors lush vegetation and desert areas on the continental coast for relatively short distances. During the dry season, the trade winds have a daily speed between 8 and $15 \mathrm{~m} / \mathrm{s}$ with a southern component; in April-June, the winds weaken being the "transition season"; during July-August, the winds intensify again — this period is called "verano". In the rainy season (August-October), the ITCZ moves north and allows the southern trade winds (winds $\sim 4 \mathrm{~m} / \mathrm{s}$ ) to cross Central America and reach the Colombia basin, where they interact with the northeast trade winds and they cause atmospheric instability that can lead to the formation of tropical cyclones in the Caribbean. Between December-March, the jet wind reaches a speed of $\sim 12 \mathrm{~m} / \mathrm{s}$ towards the west, but with a southerly component; in May, the wind decreases $(<8 \mathrm{~m} / \mathrm{s})$ and in July (summer) it increases to $>9 \mathrm{~m} / \mathrm{s}$. The weakest winds appear in October during the rains (Andrade and Barton, 2013).

In the period $1999-2008$, between $69^{\circ}-74^{\circ} \mathrm{W}$ strong winds occurred throughout the year $(>6 \mathrm{~m} / \mathrm{s})$; the maximums in June-July $(>9 \mathrm{~m} / \mathrm{s})$ and the minimums $(6-7 \mathrm{~m} / \mathrm{s})$ in September-October. The strongest winds occurred between $74^{\circ}-76^{\circ} \mathrm{W}$, with maximums in December-April (> $\left.11 \mathrm{~m} / \mathrm{s}\right)$, a secondary maximum in July $(>9 \mathrm{~m} / \mathrm{s})$, and minimums during September-October $(\sim 5 \mathrm{~m} / \mathrm{s})$. It is mentioned that, in the southwestern Caribbean, the average wind was $8.23 \mathrm{~m} / \mathrm{s}$ (Rueda-Roa, 2012; Rueda-Roa and Müller-Karger, 2013). During 1999-2009, Ekman pumping was positive near the coast, transport to the north and northwest, and the maximum magnitude to the east of the Colombia basin (Pareja et al., 2013). The mathematical morphology of the upwelling indicates its conduction through the ITCZ. Its relationship with the east-west component of the trade winds has a lag of four months. It is also related to the southern oscillation (Alonso et al., 2015).

Recent studies indicate that, in the months of intense winds, the upward movement of water is complete and clear on the surface. During the rainy season, the ascent can be partial, without the Subsurface Waters emerging. 
Aguas Subsuperficiales. La surgencia puede interrumpirse por perturbaciones atmosféricas de corto plazo (días) —como frentes fríos relacionados con vientos del norte (nortes) - y por frentes cálidos asociados con masas de aire del Pacífico tropical oriental, que generan condiciones favorables para el flujo descendente (hundimiento) en la capa superior. Durante estos periodos de relajación, la capa mixta es cálida (Montoya-Sánchez et al., 2018). En la época de lluvias, el viento es favorable a la surgencia, pero la capa superior del océano no responde al forzamiento del viento, el cual no tiene la suficiente intensidad y duración como para elevar isotermas más profundas a la superficie. De ahí que flujos geostróficos favorezcan el flujo de aguas menos densas hacia la costa, lo que inhibe más el ascenso de aguas frías (Montoya-Sánchez, 2019). Los mayores valores del índice de surgencia $\left(258,6 \mathrm{~m}^{3} / \mathrm{s}\right.$ por $100 \mathrm{~m}$ de línea de costa) se registran en febrero y luego disminuyen en los últimos meses del año $\left(19,8 \mathrm{~m}^{3} / \mathrm{s}\right.$ en octubre), pero en julio destaca un valor alto $\left(237,6 \mathrm{~m}^{3} / \mathrm{s}\right)$. Se ha planteado que, por los máximos de viento y del índice de surgencia, es posible concluir que el principal mecanismo de fertilización es la advección desde el oriente y no el transporte de Ekman (Murcia-Riaño et al., 2017).

Oriente de Venezuela. Desde mediados de la década de los años setenta, se citan valores de celeridad del viento, cuya velocidad debe ser de $>6 \mathrm{~m} / \mathrm{s}$ para que ocasione surgencia. Los valores máximos ocurren de enero a abril, con otro máximo en junio-julio y con velocidades mínimas en agosto-octubre. Los vientos provienen del ENE y NNE, pero con un componente sur en agosto-noviembre (Herrera y Febres, 1975). Con la información de estaciones costeras (1969-1990), la velocidad mensual promedio ( $>4 \mathrm{~m} / \mathrm{s}$ ) ocurre de enero a mayo, con máximos de $5 \mathrm{~m} / \mathrm{s}$ en marzo y $<4 \mathrm{~m} / \mathrm{s}$ de junio a diciembre y mínimos $(3 \mathrm{~m} / \mathrm{s})$ en septiembreoctubre (Aparicio, 2003). Los datos obtenidos (19501990) por embarcaciones mercantes (COADS y Nesdis) se consideran subestimados; los máximos y mínimos realistas son del orden de 7 y $5,5 \mathrm{~m} / \mathrm{s}$, respectivamente (Freón y Mendoza, 2003). De diciembre a junio, el viento predomina hacia occidente con máximos próximos de $6,5 \mathrm{~m} / \mathrm{s}$; el resto del año son más variables y pueden disminuir hasta $5,1 \mathrm{~m} / \mathrm{s}$ (Freón y Ans, 2003).

Entre 1994-1997, los vientos tuvieron una velocidad promedio de 7,8-8 $\mathrm{m} / \mathrm{s}$ y las surgencias predominaron hasta abril. En la estación de lluvias (mayo-noviembre), pudo ocurrir una surgencia débil o incluso hundimiento como respuesta a vientos del SSE con una velocidad de $\sim 5 \mathrm{~m} / \mathrm{s}$ (Walsh et al., 1999). En la estación Cariaco (noviembre 1995-diciembre
The upwelling can be interrupted by short-term (days) atmospheric disturbances — such as cold fronts related to northerly winds (Northerners) - and by warm fronts associated with air masses from the eastern tropical Pacific, which generate favorable conditions for the downward flow (sinking) in the top layer. During these periods of relaxation, the mixed layer is warm (Montoya-Sánchez et al., 2018). In the rainy season, the wind is favorable to upwelling, but the upper layer of the ocean does not respond to the forcing of the wind, which does not have enough intensity and duration to raise deeper isotherms to the surface. Hence, geostrophic flows favor the flow of less dense waters towards the coast, which further inhibits the rise of cold waters (MontoyaSánchez, 2019). The highest values of the upwelling index $\left(258.6 \mathrm{~m}^{3} / \mathrm{s}\right.$ per $100 \mathrm{~m}$ of coastline) are registered in February and then decrease in the last months of the year $\left(19.8 \mathrm{~m}^{3} / \mathrm{s}\right.$ in October), but in July it stands out a high value (237.6 $\mathrm{m}^{3} / \mathrm{s}$ ). It has been suggested that, due to the maximum wind and upwelling index, it is possible to conclude that the main fertilization mechanism is advection from the east and not Ekman's transport (Murcia-Riaño et al., 2017).

Eastern Venezuela. Since the mid-1970s, wind speed values have been cited, whose speed must be $>6$ $\mathrm{m} / \mathrm{s}$ to cause upwelling. The maximum values occur from January to April, with another maximum in June-July and with minimum speeds in August-October. The winds come from the ENE and NNE, but with a southern component in August-November (Herrera and Febres, 1975). With the information from coastal stations (1969-1990), the average monthly velocity ( $>4 \mathrm{~m} / \mathrm{s}$ ) occurs from January to May, with maximums of $5 \mathrm{~m} / \mathrm{s}$ in March and $<4 \mathrm{~m} / \mathrm{s}$ from June to December and minimums $(3 \mathrm{~m} / \mathrm{s})$ in SeptemberOctober (Aparicio, 2003). The data obtained (1950-1990) by merchant vessels (COADS and Nesdis) are considered underestimated; the realistic maximums and minimums are of the order of 7 and $5.5 \mathrm{~m} / \mathrm{s}$, respectively (Freón and Mendoza, 2003). From December to June, the wind predominates towards the west with maxima close to 6.5 $\mathrm{m} / \mathrm{s}$; the rest of the year they are more variable and can decrease to $5.1 \mathrm{~m} / \mathrm{s}$ (Freón and Ans, 2003).

Between 1994-1997, the winds had an average speed of 7.8-8 $\mathrm{m} / \mathrm{s}$ and upwellings predominated until April. In the rainy season (May-November), a weak upwelling or even sinking could occur in response to SSE winds with a velocity of $\sim 5 \mathrm{~m} / \mathrm{s}$ (Walsh et al., 1999). At the Cariaco station (November 1995-December 2001), the wind reached speeds of $8-9 \mathrm{~m} / \mathrm{s}$ in February-March and minimums of 
2001), el viento alcanzó velocidades de 8-9 m/s en febreromarzo y mínimos de $<4 \mathrm{~m} / \mathrm{s}$ en septiembre-octubre (Astor et al., 2004). Productos satelitales (1999-2008) del Caribe sur $\left(68^{\circ} \mathrm{W}\right)$ y cerca de la costa $(\sim 25 \mathrm{~km})$ indican que los vientos son estables en diciembre-julio $(>6 \mathrm{~m} / \mathrm{s})$ y menores $(4-6 \mathrm{~m} / \mathrm{s})$ en agosto-noviembre (Rueda-Roa, 2012).

Entre 1996-2010, se verifica el debilitamiento de los alisios (-1,9\%/año) por la migración de la ZCIT hacia el norte $\left(1,12^{\circ} \mathrm{N}\right.$ de latitud) del centro de alta presión de Azores (ramificación descendente de células Hadley) y la progresión hacia oriente del centroide atlántico (ramificación ascendente de las Hadley). Entre 1996-2009, su posición en marzo ha cambiado $\sim 800 \mathrm{~km}$ (Taylor et al., 2012).

En 18 años de estudio (1996-2013), la surgencia mostró cambios temporales y una tendencia decreciente por la disminución del viento (Astor et al., 2014). En el oriente de Venezuela, los alisios ( 3 a $9 \mathrm{~m} / \mathrm{s}$ ) persistentes sobre la plataforma causan el transporte y bombeo Ekman mar afuera (altamar) y la disminución de la temperatura superficial (1 a $3{ }^{\circ} \mathrm{C}$ ). Su variabilidad refleja el control atmosférico por parte del anticiclón del Atlántico norte y la evaporación regional. La surgencia implica una circulación atmosférica con vuelco meridional, que afecta la frecuencia de los huracanes del Caribe (Jury, 2018). En la Tabla 1 se muestran los valores mencionados. Puede concluirse que en la surgencia costera colombiana los vientos son más fuertes mientras que en el oriente de Venezuela son ligeramente menores y con tendencia decreciente en algunos años, lo que conlleva marcados cambios temporales en la surgencia e, incluso, la no ocurrencia del afloramiento.

Tabla 1. Comparación de variables y/o factores de importancia en las surgencias de la Guajira de Colombia y en el oriente de Venezuela. Los valores mencionados en hidrografía, nutrientes y clorofila $a$ corresponden al agua superficial. El superíndice después de cada valor corresponde al autor citado.
$<4 \mathrm{~m} / \mathrm{s}$ in September-October (Astor et al., 2004). Satellite products (1999-2008) of the southern Caribbean $\left(68^{\circ} \mathrm{W}\right)$ and near the coast $(\sim 25 \mathrm{~km})$ indicate that the winds are stable in December-July $(>6 \mathrm{~m} / \mathrm{s})$ and lower $(4-6 \mathrm{~m} / \mathrm{s})$ in August-November (Rueda-Roa, 2012).

Between 1996-2010, the weakening of the trade winds $(-1.9 \% /$ year $)$ was verified due to the migration of the ITCZ to the north $\left(1.12^{\circ} \mathrm{N}\right.$ of latitude) from the highpressure center of the Azores (descending branch of Hadley cells) and the eastern progression of the Atlantic centroid (upward branching of the Hadley cells). Between 19962009 , its position in March has changed by $\sim 800 \mathrm{~km}$ (Taylor et al., 2012).

In 18 years of study (1996-2013), the upwelling showed temporary changes and a decreasing trend due to the decrease in the wind (Astor et al., 2014). In eastern Venezuela, persistent trade winds ( 3 to $9 \mathrm{~m} / \mathrm{s}$ ) on the shelf cause the Ekman transport and pumping offshore (high seas) and the decrease in surface temperature $\left(1\right.$ to $\left.3^{\circ} \mathrm{C}\right)$. Its variability reflects atmospheric control by the North Atlantic anticyclone and regional evaporation. The upwelling implies an atmospheric circulation with a southerly overturn, which affects the frequency of hurricanes in the Caribbean (Jury, 2018). Table 1 shows the mentioned values. It can be concluded that, in the Colombian coastal upwelling, the winds are stronger while, in eastern Venezuela, they are slightly lower and with a decreasing trend in some years, which entails marked temporary changes in the upwelling and, even, no occurrence of the outcrop.

Table 1. Comparison of variables and/or important factors in the upwellings of the Guajira of Colombia and eastern Venezuela. The values mentioned in hydrography, nutrients, and chlorophyll- $a$ correspond to surface water. The superscript after each value corresponds to the cited author.

\begin{tabular}{|c|c|c|}
\hline Variable/Factor & $\begin{array}{l}\text { Surgencia en Guajira de Colombia/ } \\
\text { Colombian Guajira upwelling }\end{array}$ & $\begin{array}{l}\text { Surgencia en el oriente de Venezuela/ } \\
\text { Eastern Venezuela upwelling }\end{array}$ \\
\hline Vientos $(\mathrm{m} / \mathrm{seg}) /$ Winds $(\mathrm{m} / \mathrm{sec})$ & $9,5^{1} ; 8,23^{2-3} ; 8-15^{4}$ & $>6^{5} ;>4^{6} ; 6,5-5,1^{7} ; 8-5^{8} ;<4-9^{9} ; 4->6^{2} ; 3-9^{10}$ \\
\hline I. surgencia/Upwelling I. $\left(\mathrm{m}^{3} / \mathrm{s}\right)$ & $19,8-258,6^{61}$ & \\
\hline Turbulencia/Turbulence $\left(\mathrm{m}^{3} / \mathrm{s}\right)$ & $557^{2}$ & $229^{2}$ \\
\hline Temperatura/Temperature $\left({ }^{\circ} \mathrm{C}\right)$ & $25,5^{11} ; 19-25,8^{12} ; 23^{13} ;<27^{14} ; 25,5^{2} ; 24-27^{60}$ & $\begin{array}{l}22-27^{6} ; 21^{15} ; 22^{16} ; 21,79-29,15^{9} ; 20,5-22^{20} ; 25,2^{2} ; \\
21-24^{33,34} ; 24,86-25,56^{62} ; 20.1-29.1^{64}\end{array}$ \\
\hline Salinidad/Salinity & $\begin{array}{l}>36,5^{11} ; 36,5-37,2^{12} ; 35,75->36,8^{13} ; 35,8 \\
-36^{14} ; 35,2-35,3^{60}\end{array}$ & $>36,8^{16} ; 36,3^{21} ;>36,7^{33,34}$ \\
\hline Oxígeno/Oxygen (ml/L) & & $<1^{17,18,19}$ (foco surgencia) \\
\hline Nitrato/Nitrate $(\mu \mathrm{mol} / \mathrm{L})$ & $2-3^{22}$ & $6-8^{23,24} ; 14,8^{25} ; 1,2^{26-27}$ \\
\hline
\end{tabular}




\begin{tabular}{|c|c|c|}
\hline Variable/Factor & $\begin{array}{l}\text { Surgencia en Guajira de Colombia/ } \\
\text { Colombian Guajira upwelling }\end{array}$ & $\begin{array}{l}\text { Surgencia en el oriente de Venezuela/ } \\
\text { Eastern Venezuela upwelling }\end{array}$ \\
\hline Nitrito/Nitrite $(\mu \mathrm{mol} / \mathrm{L})$ & & $0,53-1^{27-28} ; 0,59-1,74^{29}$ \\
\hline Amonio/Ammonium $(\mu \mathrm{mol} / \mathrm{L})$ & & $6-17^{28} ; 2,4^{27,30} ; 3-5,5^{25} ; 2,21-2,89^{29,31} ; 2,04-2,18^{18}$ \\
\hline Fosfato/Phosphate $(\mu \mathrm{mol} / \mathrm{L})$ & & $0,15-0,53^{23,32,33,34,35} ; 1-1,5^{28} ; 1,63-3,37^{25} ;<0,3^{9} ; 0,97^{18}$ \\
\hline Clorofila $a /$ Chlorophyll- $a\left(\mathrm{mg} / \mathrm{m}^{3}\right)$ & $3^{13,36} ; 1,15^{2} ; 9,3-13,5^{60}$ & $\begin{array}{l}0,25-1,31^{37} ; 2,4^{38} ; 1,55-5,88^{39} ; 0,95-1,85^{31} ; 0,25- \\
4,5^{40} ; 1,59-2,98^{29} ; 8^{41} ; 11,1^{29} ; 14,35^{42} ; 3,7-3,8^{27} ; 0,11- \\
8,17^{43} ; 0,08-9,61^{35} ; 0,74-1,64^{44} ; 0,59-3,09^{18-19} ; 0,63^{45} \\
1,65^{2,46} ; 0,5-0,35^{62}\end{array}$ \\
\hline P. primaria/Primary production $\mathrm{gC} / \mathrm{m}^{2} / \mathrm{a}$ & & $320-628^{63}$ \\
\hline Ríos/Rivers & Magdalena & Orinoco \\
\hline Gasto $\left(\mathrm{m}^{3} / \mathrm{seg}\right) /$ Flow $\left(\mathrm{m}^{3} / \mathrm{sec}\right)$ & $7200^{48} ; 143$ (ríos Guajira) ${ }^{66}$ & $30000-80000^{49,50,51,52}$ \\
\hline Sedimentos (Mt/año)/Sediments (Mt/year) & $142,6^{47} ; 114^{48} ; 169^{65}$ & $90^{53}$ \\
\hline Área afectada/Affected area $\left(\mathrm{km}^{2}\right)$ & & $300000^{53,54}$ \\
\hline $\begin{array}{l}\text { Materia orgánica total/Total organic Matter } \\
\text { (gC/year) }\end{array}$ & & $2,5^{53}$ \\
\hline \multicolumn{3}{|c|}{ Plataforma/Platform } \\
\hline Anchura/Width (km) & $5,4-46^{55,56}$ & $90^{5}$ \\
\hline Profundidad/Depth (m) & & $66^{5}$ \\
\hline Superficie/Surface $\left(\mathrm{km}^{2}\right)$ & $14298^{57}$ & $36000^{58}$ \\
\hline $\begin{array}{l}\text { Islas, islotes/Islands, islets (número total/total } \\
\text { number) }\end{array}$ & & $167^{59}$ \\
\hline
\end{tabular}

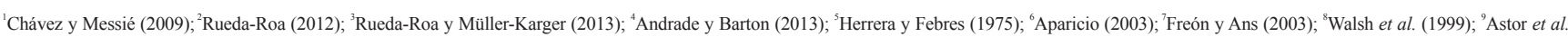
(2004); ${ }^{10} \mathrm{Jury}$ (2018); ${ }^{11}$ Fajardo (1979); ${ }^{12}$ Cabrera y Donoso (1993); ${ }^{13}$ Andrade y Barton (2005); ${ }^{14}$ Paramo et al. (2011); ${ }^{15}$ Astor et al. (2003); ${ }^{16}$ Astor et al. (1998); ${ }^{17}$ Gómez (2006); ${ }^{18}$ Gómez y Barceló (2014); ${ }^{19}$ Gómez et al. (2014); ${ }^{20}$ Castellanos et al. (2002); $;{ }^{21}$ Müller-Karger et al. (2004); ${ }^{22}$ Corredor (1977); ${ }^{23}$ Richards (1960); ${ }^{24}$ Bonilla et al. (1993); ${ }^{25}$ Ballester (1965); ${ }^{26} \mathrm{Okuda}(1978) ;{ }^{27}$ Mandelli y Ferraz (1982); ${ }^{28}$ Kato (1961); ${ }^{29} \mathrm{Gómez} \mathrm{et} \mathrm{al.} \mathrm{(2008);}{ }^{30}$ Richards y Vaccaro (1956); ${ }^{31}$ Gómez y Chanut (1988, 1993); ${ }^{32}$ Hulburt (1966); ${ }^{33}$ Okuda et al. (1969); ${ }^{34}$ Okuda (1981); ${ }^{35}$ Ferraz (1989); ${ }^{36}$ Corredor (1979); ${ }^{37}$ Margalef (1965); ${ }^{38}$ Morris et al. (1981); ${ }^{30}$ Cabrera (1987); ${ }^{40}$ Pineda y Aguado (1980); ${ }^{41}$ Varela et al. (2003); ${ }^{42}$ Gómez (2006); ${ }^{43}$ Ferraz (1987); ${ }^{4}$ Moigis (1986); ${ }^{45}$ Müller-Karger y Varela (1988); ${ }^{46}$ Muller-Karger (2013); ${ }^{47}$ Restrepo-López et al. (2015); ${ }^{48}$ Restrepo y Kjerfve (2000); ${ }^{49}$ Rabinovich y Novoa (1982); ${ }^{50}$ Meade et al. (1983); ${ }^{51}$ Lewis y Saunders (1989); ${ }^{52}$ Monente (1990); ${ }^{53}$ Blough et al. (1993); ${ }^{54}$ Müller-Karger et al. (1989); ${ }^{55}$ Álvarez-León et al. (1995); ${ }^{56}$ Paramo et al. (2003); ${ }^{57}$ Chasqui et al. (2013); ${ }^{58}$ este trabajo/This paper; ${ }^{59} \mathrm{Gómez}(1996) ;{ }^{60}$ Franco-Herrera et al. (2006); ${ }^{61}$ Montoya-Sánchez (2019); ${ }^{62}$ Lorenzoni (2017); ${ }^{63}$ Müller-Karger et al. (2019); ${ }^{64}$ Calvo-Trujillo et al. (2018); ${ }^{65}$ Higgins et al. (2016); ${ }^{66}$ Beier et al. (2017).

\section{Comentario sobre vientos e índices de surgencia}

La surgencia venezolana tiene variaciones interanuales por cambios en la velocidad del viento, que actúa a manera de pulsos e intensifica el fenómeno (Astor et al., 2004, 2014). En 1998, la surgencia fue débil y en la estación Cariaco se observó hundimiento (Müller-Karger et al., 2004). La surgencia ocurre hasta abril-mayo si los alisios del ENE tienen una velocidad de $\geq 8 \mathrm{~m} / \mathrm{s}$. Con este viento, la producción pesquera es óptima en áreas con afloramiento (Cury y Roy, 1989). Sin embargo, en el oriente de Venezuela los valores del viento tienen menor intensidad en la plataforma nororiental, donde ocurre la mayor actividad pesquera. En la estación Cariaco, el viento alcanzaba $8-9 \mathrm{~m} / \mathrm{s}$, pero esta se encontraba localizada a sotavento de la surgencia intensa y lejos de la costa (profundidad $>1000 \mathrm{~m}$ ).

En el Caribe sur, se registran vientos con diferente velocidad promedio: moderados $(6,3 \mathrm{~m} / \mathrm{seg})$ al oriente de

\section{Commentary on winds and upwelling rates}

The Venezuelan upwelling has interannual variations due to changes in wind speed, which acts as pulses and intensifies the phenomenon (Astor et al., 2004, 2014). In 1998, the upwelling was weak and subsidence was observed at the Cariaco station (Müller-Karger et al., 2004). The upwelling occurs until April-May if the ENE trade winds have a speed of $\geq 8 \mathrm{~m} / \mathrm{s}$. With this wind, fish production is optimal in upwelling areas (Cury and Roy, 1989). However, in eastern Venezuela, the wind values are less intense on the northeastern shelf, where the greatest fishing activity occurs. At the Cariaco station, the wind reached $8-9 \mathrm{~m} / \mathrm{s}$, but it was located downwind of the intense upwelling and far from the coast (depth $>1000 \mathrm{~m}$ ).

In the southern Caribbean, winds with different average speed are recorded: moderate $(6.3 \mathrm{~m} / \mathrm{sec})$ to the east — of $68^{\circ} \mathrm{W}$ (Venezuela); strong $(8.3 \mathrm{~m} / \mathrm{sec})$ — between 
Venezuela $\left(68^{\circ} \mathrm{W}\right)$, fuertes $(8,3 \mathrm{~m} / \mathrm{seg})$ en la Guajira (entre $\left.69-74^{\circ} \mathrm{W}\right)$ e intensos $(8,7 \mathrm{~m} / \mathrm{seg})$ afuera de Colombia (entre $\left.74-76^{\circ} \mathrm{W}\right)$. En esta área, el proceso de surgencia es menos eficiente por una menor proporción de vientos alineados con la dirección de la costa (85 \% y $94 \%$ para las áreas occidental y oriental del Caribe sur). Además, al occidente se alcanza una latitud ligeramente más alta y el parámetro Coriolis ocasiona $\sim 10 \%$ menos de transferencia del viento a la surgencia (Rueda-Roa, 2012). En la parte oriental de la cuenca Cariaco (1994-2009), el transporte de Ekman varió entre 1,35-2,77 m²/s (Lorenzoni et al., 2017).

En la Guajira, los valores más altos del índice de surgencia $\left(258,6 \mathrm{~m}^{3} / \mathrm{s}\right.$ por $100 \mathrm{~m}$ de línea de costa) se registran en febrero, disminuyen en octubre $\left(19,8 \mathrm{~m}^{3} / \mathrm{s}\right)$ y en julio alcanzan 237,6 m $/ \mathrm{s}$ (Murcia-Riaño et al., 2017). En la surgencia colombiana, el transporte es 1,5 veces mayor que en el oriente venezolano porque los vientos son 1,3 veces más fuertes. En consecuencia, en la columna de agua, la turbulencia es $\sim 2,5$ veces mayor en el occidente que en el oriente (557 y $229 \mathrm{~m}^{3} / \mathrm{s}$, respectivamente). Esto tiene mucha importancia porque puede limitar la producción pesquera al dispersar el plancton y transportar las larvas mar afuera y a mayor profundidad; así mismo, se ha planteado que en la Guajira los nutrientes se exportan antes de ser utilizados en la surgencia (Rueda-Roa, 2012). De igual forma, debe considerarse la dirección de la costa, que en Colombia es hacia el suroccidente (Punta Gallinas a Camarones) y de oriente a occidente (Camarones a Santa Marta) mientras que en Venezuela es de oriente a occidente.

Para determinar la influencia del viento como factor responsable de la surgencia, se han establecido índices (Bakun, 1973) porque dan idea del transporte de Ekman como índice del agua que asciende para reemplazar a la superficial que desplaza el viento. Asimismo, se calculan índices utilizando campos de presión atmosférica (vientos geostróficos) y la temperatura superficial del agua (Aparicio, 2003), y con las variables de viento y temperatura se establecen correlaciones para modelos predictivos (Herrera y Febres, 1975).

En Venezuela, se han utilizados datos de vientos de estaciones meteorológicas (Herrera y Febres, 1975; Aparicio, 2003), viento marítimo y temperatura del mar (1950-1990) por barcos mercantes (Freón y Ans, 2003). El problema con estos datos es que los barcos generalmente sobrepasan la plataforma y la surgencia venezolana es costera, por lo cual quizás sean más apropiados los datos de las estaciones fijas, que también tienen sesgo por interferencia de las brisas marinas (de tierra y mar) con los vientos alisios (Freón y Mendoza, 2003). $69^{\circ}-74^{\circ} \mathrm{W}$ (Guajira), and intense —of $8.7 \mathrm{~m} / \mathrm{sec}$ between $74^{\circ}-76^{\circ} \mathrm{W}$ (outside Colombia). In this area, the upwelling process is less efficient due to a lower proportion of winds aligned with the direction of the coast ( $85 \%$ and $94 \%$ for the western and eastern areas of the southern Caribbean). Also, to the west, a slightly higher latitude is reached and the Coriolis parameter causes $\sim 10 \%$ less transfer from the wind to the upwelling (Rueda-Roa, 2012). In the eastern part of the Cariaco basin (1994-2009), Ekman transport ranged between $1.35-2.77 \mathrm{~m}^{2} / \mathrm{s}$ (Lorenzoni et al., 2017).

In La Guajira, the highest values of the upwelling index $\left(258.6 \mathrm{~m}^{3} / \mathrm{s}\right.$ per $100 \mathrm{~m}$ of coastline $)$ are registered in February, decreasing in October $\left(19.8 \mathrm{~m}^{3} / \mathrm{s}\right)$ and reaching $237.6 \mathrm{~m}^{3} / \mathrm{s}$ in July (Murcia-Riaño et al., 2017). In the Colombian upwelling, transport is 1.5 times larger than in eastern Venezuela because the winds are 1.3 times stronger. Consequently, in the water column, turbulence is $\sim 2.5$ times greater in the west than in the east (557 and $229 \mathrm{~m}^{3} / \mathrm{s}$, respectively). This is very important because it can limit fish production by dispersing plankton and transporting larvae offshore and deeper; likewise, it has been proposed that in La Guajira nutrients are exported before being used in the upwelling (Rueda-Roa, 2012). Similarly, the direction of the coast must be considered, which in Colombia is to the southwest (Punta Gallinas to Camarones) and from east to west (Camarones to Santa Marta) while in Venezuela it is from east to west.

To determine the influence of the wind as a factor responsible for upwelling, indices have been established (Bakun, 1973) because they give an idea of Ekman's transport as an index of the water that rises to replace the surface water displaced by the wind. Likewise, indices are calculated using atmospheric pressure fields (geostrophic winds) and water surface temperature (Aparicio, 2003), and with the wind and temperature variables correlations are established for predictive models (Herrera and Febres, 1975).

In Venezuela, wind data from meteorological stations (Herrera and Febres, 1975; Aparicio, 2003), maritime wind and sea temperature (1950-1990) by merchant ships (Freón and Ans, 2003) have been used. The problem with these data is that the ships generally exceed the shelf and the Venezuelan upwelling is coastal, so perhaps the data from the fixed stations are more appropriate, which are also biased by interference from sea winds (land and sea) with the trade winds (Freón and Mendoza, 2003). 
Según registros de barcos (1950-1990), el promedio presenta máximos estables entre diciembre-junio con valores cercanos a $6,5 \mathrm{~m} / \mathrm{s}$, que disminuyen hasta $5,1 \mathrm{~m} / \mathrm{s}$ en otros meses. La temperatura mostró gran regularidad, con mínimos de $<26{ }^{\circ} \mathrm{C}$ en febrero-marzo y máximos de $>28{ }^{\circ} \mathrm{C}$ en septiembre-octubre (Freón y Ans, 2003). Sin embargo, valores de $<26^{\circ} \mathrm{C}$ son muy altos para indicar surgencia en Venezuela porque $21-22{ }^{\circ} \mathrm{C}$ en superficie son señal de afloramiento intenso. Al tener datos conflictivos de vientos y temperatura, es difícil aplicar la hipótesis de la ventana óptima de reclutamiento en el caso venezolano, ya que los datos costeros indican que la reproducción de la sardina venezolana (Sardinella aurita) ocurre por debajo del valor óptimo de $5,5 \mathrm{~m} / \mathrm{s}$ mientras que, por los buques, ocurre alrededor del valor óptimo (Freón y Mendoza, 2003). La reproducción de la sardina venezolana se produce en áreas próximas a la costa (Gómez, 2006, 2015; Gómez y Hernández, 2008). En general, las hipótesis de reclutamiento y ventana óptima, entre otras, pueden ser útiles en las áreas donde fueron formuladas, pero tienen dudosa aplicabilidad en ecosistemas tropicales, como el de Venezuela.

La tendencia reciente es utilizar índices que incluyan otras variables para intentar predecir con más realismo y poder explicar la variabilidad de poblaciones. Por ejemplo, en series de tiempo largas, el índice de nutrientes que utiliza nitrato y temperatura responde mejor para predecir la concentración de clorofila y abundancia del zooplancton (García-Reyes et al., 2014). De igual forma, se reconoce que el manejo de ecosistemas pelágicos debe integrar los estudios físicos con funciones biológicas porque la variación estacional de vientos favorables para la surgencia influencia de manera diferente a las especies, como es el caso de la sardina en California (García-Reyes et al., 2013), y de la sardina Sardinella aurita del Caribe sur.

\section{HIDROGRAFÍA DEL AGUA QUE AFLORA}

Guajira de Colombia. En septiembre de 1972, observaciones oceanográficas en el Caribe colombiano (71$\left.75^{\circ} \mathrm{W}\right)$, en adyacencias de la península Guajira $\left(72^{\circ} \mathrm{W}\right)$, encontraron aguas con temperatura de $25,5^{\circ} \mathrm{C}$ y salinidad de $>36,5$ y movimientos ascendentes con intensidad de $\sim 114 \mathrm{~m} / \mathrm{mes}$ (Fajardo, 1979). En 1975, durante la surgencia, las concentraciones máximas de nitrato en superficie fueron 2-3 $\mu \mathrm{mol} / \mathrm{L}$ (Corredor, 1977), valores que reflejan la fuente o masa de Agua Subtropical Subsuperficial (SUW). El crecimiento del fitoplancton es menor que en otras
According to ship records (1950-1990), the average shows stable maximums between December-June with values close to $6.5 \mathrm{~m} / \mathrm{s}$, which decrease to $5.1 \mathrm{~m} / \mathrm{s}$ in other months. The temperature showed great regularity, with minimums of $<26{ }^{\circ} \mathrm{C}$ in February-March and maximums of $>28{ }^{\circ} \mathrm{C}$ in September-October (Freón and Ans, 2003). However, values of $<26{ }^{\circ} \mathrm{C}$ are too high to indicate upwelling in Venezuela because $21-22{ }^{\circ} \mathrm{C}$ on the surface are a sign of intense upwelling. Having conflicting data on winds and temperature, it is difficult to apply the hypothesis of the optimal recruitment window in the Venezuelan case, since the coastal data indicate that the reproduction of the Venezuelan sardine (Sardinella aurita) occurs below the optimal value of $5.5 \mathrm{~m} / \mathrm{s}$ while, for the vessels, it occurs around the optimal value (Freón and Mendoza, 2003). The reproduction of the Venezuelan sardine occurs in areas close to the coast (Gómez, 2006, 2015; Gómez and Hernández, 2008). In general, the recruitment and optimal window hypotheses, among others, may be useful in the areas where they were formulated, but they have doubtful applicability in tropical ecosystems, such as Venezuela.

The recent trend is to use indices that include other variables to try to predict with more realism and to be able to explain the variability of populations. For example, in long time series, the nutrient index that uses nitrate and temperature responds better to predict chlorophyll concentration and abundance of zooplankton (García-Reyes et al., 2014). In the same way, it is recognized that the management of pelagic ecosystems must integrate physical studies with biological functions because the seasonal variation of favorable winds for upwelling influences species differently, as is the case of the sardine in California (García-Reyes et al., 2013), and the sardine Sardinella aurita from the South Caribbean.

\section{HYDROGRAPHY OF THE WATER THAT EMERGES}

Colombian Guajira. In September 1972, oceanographic observations in the Colombian Caribbean $\left(71^{\circ}-75^{\circ} \mathrm{W}\right)$, in the vicinity of the Guajira peninsula $\left(72^{\circ} \mathrm{W}\right)$, found waters with a temperature of $25.5{ }^{\circ} \mathrm{C}$ and salinity of $>36.5$ and movements ascending with an intensity of $\sim 114 \mathrm{~m} /$ month (Fajardo, 1979). In 1975, during the upwelling, the maximum concentrations of nitrate on the surface were $2-3 \mu \mathrm{mol} / \mathrm{L}$ (Corredor, 1977), values that reflect the source or mass of Subtropical Subsurface 
surgencias a causa del relativo empobrecimiento del agua fuente (Corredor, 1979). Se menciona que aflora SUW, con temperaturas entre $22,6-25,8{ }^{\circ} \mathrm{C}$ y que en los focos de surgencia activa tiene hasta $19{ }^{\circ} \mathrm{C}$ y salinidades entre 36,5 y 37,2 (Cabrera y Donoso, 1993). En 1994 (abril), el foco fuerte se localizó en $12,5^{\circ} \mathrm{N}$, con una temperatura superficial de $23{ }^{\circ} \mathrm{C}$ y una isoterma alrededor de $25{ }^{\circ} \mathrm{C}$. Hasta $100 \mathrm{~km}$ de la costa se observó circulación ciclónica (Andrade y Barton, 2005).

En 1998 (febrero), la temperatura superficial fue de $23{ }^{\circ} \mathrm{C}$ (salinidad de $>36,8$ ), pero en el borde de la plataforma, desde la superficie hasta $200 \mathrm{~m}$ de profundidad, se encontraron salinidades de 36,4. En noviembre de 1998 fue característico que el agua surgida estuviera rodeada por agua cálida con menor salinidad — hasta 35,75 — (Andrade y Barton, 2005). Al sur de la Guajira, en el parque Tayrona (septiembre/1999-mayo/2000), la temperatura varió entre $24,0-27,0^{\circ} \mathrm{C}$ y la salinidad entre $35,2-35,3$ en época seca (surgencia) (Franco-Herrera et al., 2006). En la Guajira, los trabajos se han centrado en mediciones indirectas y datos in situ de cruceros, que determinan temperatura y salinidad (Andrade y Barton, 2005; Paramo et al., 2011). Recientemente, estas variables, además del oxígeno disuelto y nutrientes, se han extraído de la climatología del World Ocean Atlas 2009 (Bastidas-Salamanca et al., 2017; MurciaRiaño et al., 2017).

Durante 1981-2000, las temperaturas superficiales obtenidas por barcos (COADS) indican que, en la baja y alta Guajira, el promedio fue de $27,08{ }^{\circ} \mathrm{C}$. En febreromarzo, se presentan los mínimos $\left(24,43\right.$ y $\left.24,50{ }^{\circ} \mathrm{C}\right)$ y en octubre-noviembre los máximos $\left(29,45\right.$ y $\left.29,54{ }^{\circ} \mathrm{C}\right)$, con un intervalo anual de 4,95 y $5,07{ }^{\circ} \mathrm{C}$ (Bernal et al., 2006). Cerca de la costa (finales de 2005 hasta febrero/2006), las temperaturas superficiales fueron de $\leq 27^{\circ} \mathrm{C}$ (salinidad de 36) y de $23^{\circ} \mathrm{C}$ (salinidad de 35,8 ), en una profundidad de $>30 \mathrm{~m}$ (Paramo et al., 2011). También se menciona que se trata de SUW (Wüst, 1964; Fajardo, 1979; Bula, 1990) localizada entre 100 y $200 \mathrm{~m}$ de profundidad (Hernández y Joyce, 2000). Sin embargo, se considera que el agua que abastece a la surgencia en la Guajira puede estar influenciada por una rama costera (extremo sur) del giro Panamá-Colombia, que fluye a $100 \mathrm{~m}$ de profundidad y con dirección hacia el oriente (Andrade, 2001; Andrade et al., 2003; Jouanno et al., 2008) como una corriente subsuperficial (Beier et al., 2017); su origen determina la baja cantidad de nutrientes del agua que emerge con la surgencia (Paramo et al., 2011). El giro ciclónico tiene más
Water (SUW). Phytoplankton growth is less than in other upwellings due to the relative impoverishment of the source water (Corredor, 1979). It is mentioned that SUW upwellings, with temperatures between $22.6-25.8{ }^{\circ} \mathrm{C}$ and that in active upwelling foci it has up to $19^{\circ} \mathrm{C}$ and salinities between 36.5 and 37.2 (Cabrera and Donoso, 1993). In 1994 (April), the strong focus was located at $12.5^{\circ} \mathrm{N}$, with a surface temperature of $23{ }^{\circ} \mathrm{C}$ and an isotherm around 25 ${ }^{\circ} \mathrm{C}$. Up to $100 \mathrm{~km}$ from the coast, cyclonic circulation was observed (Andrade y Barton, 2005).

In 1998 (February), the surface temperature was $23{ }^{\circ} \mathrm{C}$ (salinity $>36.8$ ), but at the edge of the shelf, from the surface to $200 \mathrm{~m}$ depth, salinities of 36.4 were found. In November 1998 it was characteristic that the emerged water was surrounded by warm water with lower salinity - up to 35.75 (Andrade and Barton, 2005). South of La Guajira, in Tayrona Park (September/1999-May/2000), the temperature varied between $24.0-27.0^{\circ} \mathrm{C}$ and the salinity between 35.2 35.3 in the dry season (upwelling) (Franco-Herrera et al., 2006). In La Guajira, researchers have focused on indirect measurements and in situ data from cruise ships, which determine temperature and salinity (Andrade and Barton, 2005; Paramo et al., 2011). Recently, these variables, in addition to dissolved oxygen and nutrients, have been extracted from the climatology of the World Ocean Atlas 2009 (Bastidas-Salamanca et al., 2017; Murcia-Riaño et al., 2017).

During 1981-2000, the surface temperatures obtained by ships (COADS) indicate that, in the low and high Guajira, the average was $27.08^{\circ} \mathrm{C}$. In February-March, the minimums $\left(24.43\right.$ and $\left.24.50{ }^{\circ} \mathrm{C}\right)$ are presented and in October-November the maximums $\left(29.45\right.$ and $\left.29.54{ }^{\circ} \mathrm{C}\right)$, with an annual interval of 4.95 and $5.07^{\circ} \mathrm{C}$ (Bernal et al., 2006). Near the coast (late 2005 to February/2006), surface temperatures were $\leq 27{ }^{\circ} \mathrm{C}$ (salinity of 36 ) and $23{ }^{\circ} \mathrm{C}$ (salinity of 35.8), at a depth of $>30 \mathrm{~m}$ (Paramo et al., 2011). It is also mentioned that it is SUW (Wüst, 1964; Fajardo, 1979; Bula, 1990) located between 100 and $200 \mathrm{~m}$ deep (Hernández and Joyce, 2000). However, it is considered that the water that supplies the upwelling in the Guajira may be influenced by a coastal branch (extreme south) of the Panama-Colombia gyre, which flows $100 \mathrm{~m}$ deep and in an eastern direction (Andrade, 2001; Andrade et al., 2003; Jouanno et al., 2008) as a subsurface current (Beier et al., 2017), its origin determines the low amount of nutrients in the water that emerges with the upwelling (Paramo et al., 2011). The cyclonic gyre is more than $200 \mathrm{~km}$ wide and 
de $200 \mathrm{~km}$ de ancho y una velocidad media de $>60 \mathrm{~cm} / \mathrm{s}$ (Bernal et al., 2010). La parte occidental del giro persiste todo el año (Centurioni y Niiler, 2003), pero la parte oriental se desprende aguas afuera del golfo del Darién, lo que forma la contracorriente Panamá-Colombia (Andrade, 2001; Ruiz Ochoa, 2011), cuya intensidad varía con la estacionalidad. La contracorriente se vuelve más pronunciada en época de lluvias (húmeda) y se extiende hasta la Guajira (Donoso, 1990). En general, en aguas de la plataforma y del talud continental del Caribe centroamericano (Belice hasta el sur del Caribe colombiano), donde se forma el giro, los perfiles verticales son típicos de aguas oligotróficas (Aguirre y Salmerón, 2015; Brenes et al., 2017) y en los primeros $100 \mathrm{~m}$ la temperatura varía poco (Sheng y Tang, 2003). En consecuencia, el giro Panamá-Colombia es oligotrófico.

El análisis de cambios en la intensidad de la surgencia entre 1982-2014 (Santos et al., 2016) determina diferencias entre calentamiento en mar abierto $(\sim 0,25$ ${ }^{\circ} \mathrm{C} / \mathrm{dec}$ ) y localidades costeras que tienen enfriamiento moderado no significante $\left(\sim-0,05^{\circ} \mathrm{C} / \mathrm{dec}\right)$. En los meses de surgencia fuerte (enero-marzo), la temperatura mínima $\left(24,5^{\circ} \mathrm{C}\right)$ estuvo entre 73 y $72^{\circ} \mathrm{W}$ y el índice máximo de surgencia $\left(4 \mathrm{~m}^{2} / \mathrm{s}\right)$ entre 75,5 y $74,5^{\circ} \mathrm{W}$. El desplazamiento de la temperatura mínima $\left(\sim 2^{\circ}\right)$ hacia el oriente puede tener relación con la advección de aguas provocada por la contracorriente costera del Caribe (Andrade et al., 2003; Jouanno et al., 2008). Estas aguas son más intensas entre diciembre y mayo (Bernal et al., 2010).

Se menciona que en el Caribe colombiano (Bastidas-Salamanca et al., 2017) se observa desde agosto baja salinidad asociada con plumas de los ríos Orinoco y Amazonas, las cuales se extienden a lo largo del Caribe entre agosto-noviembre, tres a cuatro meses después del máximo de lluvias (Chérubin y Richardson, 2007). En octubre-noviembre, se suman al pulso del río Magdalena y de otros ríos que drenan al Caribe. Lo anterior se corresponde con las más bajas salinidades en el ciclo anual, que llevan consigo nutrientes provenientes del continente. Se cita, así mismo, que en el oriente de la Guajira se presenta un pulso de alta concentración en febrero y julio, el cual podría explicarse como una advección proveniente del oriente; no obstante, no se evidencia un aporte directo asociado a la surgencia de la Guajira (Bastidas-Salamanca et al., 2017). También se menciona que la surgencia es casi permanente por combinación de la morfología costera, la batimetría y la persistencia hacia occidente de los vientos alisios; el evento más importante ocurre entre diciembre-mayo y otra surgencia has an average speed of $>60 \mathrm{~cm} / \mathrm{s}$ (Bernal et al., 2010). The western part of the gyre persists throughout the year (Centurioni and Niiler, 2003), but the eastern part flows out of the Darien Gulf, forming the Panama-Colombia Countercurrent (Andrade, 2001; Ruiz Ochoa, 2011), whose intensity varies with seasonality. The countercurrent becomes more pronounced in the rainy season (wet) and extends to La Guajira (Donoso, 1990). In general, in waters of the continental shelf and slope of the Central American Caribbean (Belize to the southern Colombian Caribbean), where the gyre is formed, the vertical profiles are typical of oligotrophic waters (Aguirre and Salmerón, 2015; Brenes et al., 2017) and in the first $100 \mathrm{~m}$ the temperature varies little (Sheng and Tang, 2003). Consequently, the PanamaColombia gyre is oligotrophic.

The analysis of changes in the intensity of the upwelling between 1982-2014 (Santos et al., 2016) determines differences between warming in the open sea $\left(\sim 0.25{ }^{\circ} \mathrm{C} / \mathrm{dec}\right)$ and coastal localities that have moderate non-significant cooling $\left(\sim-0.05{ }^{\circ} \mathrm{C} / \mathrm{dec}\right)$. In the months of strong upwelling (January-March), the minimum temperature $\left(24.5^{\circ} \mathrm{C}\right)$ was between $73^{\circ}$ and $72^{\circ} \mathrm{W}$ and the maximum upwelling rate $\left(4 \mathrm{~m}^{2} / \mathrm{s}\right)$ between $75.5^{\circ}$ and 74.5 ${ }^{\circ} \mathrm{W}$. The displacement of the minimum temperature towards the east $\left(\sim 2^{\circ}\right)$ may be related to the flow of water caused by the coastal countercurrent of the Caribbean (Andrade et al., 2003; Jouanno et al., 2008). These waters are most intense between December and May (Bernal et al., 2010).

It is mentioned that in the Colombian Caribbean (Bastidas-Salamanca et al., 2017) low salinity has been observed since August associated with plumes from the Orinoco and Amazon rivers, which extend throughout the Caribbean between August-November, three to four months after the maximum rainfall (Chérubin and Richardson, 2007). In October-November, they join the pulse of the Magdalena River and other rivers that drain into the Caribbean. This corresponds to the lowest salinities in the annual cycle, which carry nutrients that come from the continent. Likewise, it is mentioned that in eastern La Guajira there is a high concentration pulse in February and July, which could be explained as an advection from the east; however, there is no evidence of a direct contribution associated with the emergence of the Guajira (Bastidas-Salamanca et al., 2017). It is also mentioned that the upwelling is almost permanent due to a combination of the coastal morphology, the bathymetry and the persistence towards the west of the trade winds; the most important event occurs between 
débil en junio-agosto por la intensificación del viento de chorro de bajo nivel del Caribe (Cook y Vizy, 2010). Con modelos armónicos, Del Rosario et al. (2019) establecen predicciones de la surgencia con un horizonte entre 4-6 meses.

Son variadas las explicaciones para la baja productividad en la Guajira: se habla de las aguas oligotróficas (Andrade et al., 2003), de la eficiencia reducida en la transferencia de energía por el viento (Rueda-Roa y Müller-Karger, 2013) y de que en junio-diciembre las aguas superficiales tienen baja salinidad al tener su origen en el suroccidente de la cuenca Colombia, lo cual favorece la estratificación y el calentamiento e inhibe la mezcla vertical (Beier et al., 2017). También se ha planteado que, según la época del año, la fuente de la fertilización viene del oriente, a través de remolinos de mesoescala, transportando nutrientes desde el golfo de Venezuela, desde focos de surgencia cercanos e incluso desde la cuenca Cariaco (oriente de Venezuela), o viene del occidente, por la descarga del río Magdalena, y es transportada por la contracorriente del Caribe (Murcia-Riaño et al., 2017).

Con datos satelitales (1999-2008), se estableció que el promedio anual de temperatura superficial es de $\geq 25,5^{\circ} \mathrm{C}$. En Santa Marta, se encontró la menor amplitud anual $\left(2,8^{\circ} \mathrm{C}\right)$, con un límite de surgencia de $75,5^{\circ} \mathrm{W}$, porque hasta $77^{\circ} \mathrm{W}$ el promedio anual es $27,4{ }^{\circ} \mathrm{C}$ (RuedaRoa, 2012). La surgencia afecta un área de $110000 \mathrm{~km}^{2}$ en el Caribe suroccidental (Castellanos et al., 2002).

Recientemente, utilizando modelos numéricos y algunos perfiles oceanográficos (Correa-Ramírez et al., 2020), se plantea que en las surgencias de la Guajira y Venezuela aflora Agua Subtropical, que se forma en la plataforma de Nicaragua y es transportada por debajo del giro Panamá-Colombia por la contracorriente de Colombia (velocidad promedio de $\sim 0,28 \mathrm{~m} / \mathrm{s}$ ). La menor salinidad observada en las aguas afloradas resulta de intensos procesos verticales de mezcla. Desde Nicaragua, la corriente viaja entre 2600 y $4400 \mathrm{~km}$ antes de alcanzar la Guajira y el oriente de Venezuela, con un tiempo de permanencia de 3,6 y 6,1 meses, respectivamente. Antes de aflorar en las costas de ambos países, este tiempo contribuye al aumento (o la disminución) de nutrientes en el Agua Subtropical (CorreaRamírez et al., 2020). También se ha concluido que en la surgencia de la Guajira ocurre calentamiento en toda la capa superficial (Montoya-Sánchez, 2019).

Oriente de Venezuela. Por información de barcos (COADS) entre 1959-1990, la temperatura superficial
December-May and another weak upwelling in June-August due to the intensification of the low-level jet wind from the Caribbean (Cook and Vizy, 2010). With harmonic models, Del Rosario et al. (2019) established upwelling predictions with a horizon between 4-6 months.

The explanations for the low productivity in La Guajira are varied: oligotrophic waters (Andrade et al., 2003) reduced efficiency in the transfer of energy by the wind (Rueda-Roa and Müller-Karger, 2013), and of that in June-December surface waters have low salinity as they originate in the southwest of the Colombia basin, which favors stratification and warming and inhibits vertical mixing (Beier et al., 2017). It has also been suggested that depending on the time of year, the source of fertilization comes from the east, through mesoscale eddies, transporting nutrients from the Gulf of Venezuela, from nearby upwelling sources and even from the Cariaco basin (eastern Venezuela), or it comes from the west, by the discharge of the Magdalena River, and is transported by the Caribbean Countercurrent (Murcia-Riaño et al., 2017).

With satellite data (1999-2008), it was established that the average annual surface temperature is $\geq 25.5^{\circ} \mathrm{C}$. In Santa Marta, the lowest annual amplitude was found $\left(2.8{ }^{\circ} \mathrm{C}\right)$, with an upwelling limit of $75.5^{\circ} \mathrm{W}$, because up to $77^{\circ} \mathrm{W}$ the annual average is $27.4^{\circ} \mathrm{C}$ (Rueda-Roa, 2012). The upwelling affects an area of $110,000 \mathrm{~km}^{2}$ in the southwestern Caribbean (Castellanos et al., 2002).

Recently, using numerical models and some oceanographic profiles (Correa-Ramírez et al., 2020), it has been suggested that Subtropical Water emerges in the upwellings of La Guajira and Venezuela, which forms on the Nicaraguan platform and is transported below the gyre. Panama-Colombia by the Colombia Countercurrent (average speed of $\sim 0.28 \mathrm{~m} / \mathrm{s}$ ). The lower salinity observed in the upwelling waters results from intense vertical mixing processes. From Nicaragua, the current travels between 2600 and $4400 \mathrm{~km}$ before reaching Guajira and eastern Venezuela, with a residence time of 3.6 and 6.1 months, respectively. Before emerging on the coasts of both countries, this time contributes to the increase (or decrease) of nutrients in Subtropical Water (Correa-Ramírez et al., 2020). It has also been concluded that warming occurs in the entire surface layer in the Guajira upwelling (MontoyaSánchez, 2019).

Eastern Venezuela. Based on information from ships (COADS) between 1959-1990, the surface 
presenta regularidad, con valores mínimos de $<26{ }^{\circ} \mathrm{C}$ en febrero-marzo y máximos de $>28^{\circ} \mathrm{C}$ en septiembre-octubre; la amplitud de variación es menor que las mediciones costeras (Freón y Ans, 2003). Por datos de mareógrafos (1968-1986), la temperatura superficial tuvo un mínimo de $\sim 22{ }^{\circ} \mathrm{C}$ el primer trimestre del año, con máximos de $\sim 27$ ${ }^{\circ} \mathrm{C}$ en septiembre-octubre y una amplitud anual de $5{ }^{\circ} \mathrm{C}$ (Aparicio, 2003). Se menciona que hubo dificultad en el registro de la hidrografía regional porque las observaciones oceanográficas permanentes han sido infrecuentes; además, en el movimiento vertical del agua ocurre un patrón irregular, por lo cual la isoterma de $21^{\circ} \mathrm{C}$ en superficie se utiliza para definir la surgencia fuerte o intensa, aunque en 1997 y 1998 la isoterma de $23{ }^{\circ} \mathrm{C}$ fue la que afloró en superficie (Astor et al., 2003). Asimismo, en 1933 y 1937, la temperatura superficial fue de $24{ }^{\circ} \mathrm{C}$, lo que demostró que la surgencia no fue intensa (Herrera y Febres, 1975).

En la serie de tiempo Cariaco (1995-2017), se observaron surgencias en los primeros años (diciembre/1995 y abril/1996), cuando la temperatura en superficie fue de $<22,5{ }^{\circ} \mathrm{C}$. En diciembre/1996-mayo/1997 fue de $<22{ }^{\circ} \mathrm{C}$. En ambos eventos, la salinidad fue de $>36,8$ en superficie. También se menciona que a $120 \mathrm{~m}$ el oxígeno disuelto tuvo una concentración de $2,6 \mathrm{ml} / \mathrm{L}$, valor observado a $50 \mathrm{~m}$ en febrero de 1997, lo que indicó el ascenso de aguas profundas (Astor et al., 1998). Durante la surgencia, el pH es bajo $(<8,0)$ en aguas superficiales (Astor et al., 2017). Entre noviembre/1995-diciembre/2001, la temperatura superficial varió entre 21,79 y $29,1{ }^{\circ} \mathrm{C}$. En 1997 y 2001, ocurrieron surgencias fuertes cuando la isoterma de $21{ }^{\circ} \mathrm{C}$ alcanzó una profundidad de 18-21 m, pero en 1998 y 1999 la isoterma de $21{ }^{\circ} \mathrm{C}$ tuvo menor intensidad porque permaneció por debajo de $40 \mathrm{~m}$, razón por la cual la surgencia fue débil (Walsh et al., 1999; Astor et al., 2004, 2005). En el oriente de isla Margarita, en marzo de 2003-2004, durante la surgencia intensa se determinaron valores de oxígeno disuelto de $<1 \mathrm{ml} / \mathrm{L}$ en superficie (Gómez, 2006; Gómez y Barceló, 2014).

En 1996, por imágenes satelitales, se identificaron 13 focos de surgencia, de los cuales 7 tuvieron temperaturas entre $21-22^{\circ} \mathrm{C}$ (mínimo $20,5^{\circ} \mathrm{C}$ ). Cuando son muy intensos, los focos se unen formando extensas zonas de agua fría, que alcanzan un área de hasta $52000 \mathrm{~km}^{2}$ (Castellanos et al., 2002), valor próximo a la estimación previa de $\sim 55000 \mathrm{~km}^{2}$ (Gómez, 1996). Según la intensidad del viento, las aguas ascienden desde una profundidad de 120-140 m, donde se localiza el Agua Subtropical que aflora en febrero-marzo, y entonces agua con salinidad de 36,9 alcanza la superficie. temperature shows regularity with minimum values of $<$ $26{ }^{\circ} \mathrm{C}$ in February-March and maximum values of $>28$ ${ }^{\circ} \mathrm{C}$ in September-October; the range of variation is less than coastal measurements (Freon and Ans, 2003). Based on tide gauge data (1968-1986), the surface temperature had a minimum of $\sim 22{ }^{\circ} \mathrm{C}$ in the first quarter of the year, with maximums of $\sim 27^{\circ} \mathrm{C}$ in September-October and an annual amplitude of $5{ }^{\circ} \mathrm{C}$ (Aparicio, 2003). It is mentioned that there was difficulty in recording regional hydrography because permanent oceanographic observations have been infrequent; furthermore, an irregular pattern occurs in the vertical movement of water, so the isotherm of $21{ }^{\circ} \mathrm{C}$ on the surface is used to define strong or intense upwelling, although in 1997 and 1998 the $23{ }^{\circ} \mathrm{C}$ isotherm was the one that surfaced (Astor et al., 2003). Likewise, in 1933 and 1937 , the surface temperature was $24^{\circ} \mathrm{C}$, which showed that the upwelling was not intense (Herrera and Febres, 1975).

In the Cariaco time series (1995-2017), upwellings were observed in the first years (December/1995 and April/1996), when the surface temperature was $<22.5{ }^{\circ} \mathrm{C}$. In December/1996-May/1997 it was $<22{ }^{\circ} \mathrm{C}$. In both events, salinity was $>36.8$ on the surface. They also mention that at $120 \mathrm{~m}$ the dissolved oxygen had a concentration of 2.6 $\mathrm{ml} / \mathrm{L}$, a value observed at $50 \mathrm{~m}$ in February 1997, which indicated the ascent of deep waters (Astor et al., 1998). During the upwelling, the $\mathrm{pH}$ is low $(<8.0)$ in surface waters (Astor et al., 2017). Between November/1995December/2001, the surface temperature varied between 21.79 and $29.15^{\circ} \mathrm{C}$. In 1997 and 2001, strong upwellings occurred when the $21{ }^{\circ} \mathrm{C}$ isotherm reached a depth of 18 $21 \mathrm{~m}$, but in 1998 and 1999 the $21{ }^{\circ} \mathrm{C}$ isotherm had less intensity because it remained below $40 \mathrm{~m}$, which is why the upwelling was weak (Walsh et al., 1999; Astor et al., 2004, 2005). In the east of Isla Margarita, in March 2003-2004, during the intense upwelling, dissolved oxygen values of $<1$ $\mathrm{ml} / \mathrm{L}$ were determined on the surface (Gómez, 2006; Gómez and Barceló, 2014).

In 1996, by satellite images, 13 sources of upwelling were identified, of which 7 had temperatures between $21-22{ }^{\circ} \mathrm{C}$ (minimum $20.5{ }^{\circ} \mathrm{C}$ ). When they are very intense, the foci unite to form extensive areas of cold water, which reach an area of up to $52000 \mathrm{~km}^{2}$ (Castellanos et al., 2002), a value close to the previous estimate of $\sim 55000 \mathrm{~km}^{2}$ (Gómez, 1996). Depending on the intensity of the wind, the waters rise from a depth of 120-140 m, where the Subtropical Water that emerges in February-March is located, and then water with salinity of 36.9 reaches the 
Este fenómeno se aprecia hasta mayo. De agosto a octubre, el agua superficial es cálida $\left(>28^{\circ} \mathrm{C}\right)$ y de menor salinidad $(36,3)$, coincidiendo con la época de lluvias (Müller-Karger et al., 2004). También, con base en imágenes (1999-2008), se menciona que, en la surgencia venezolana (oriente de $68^{\circ} \mathrm{W}$ ), la temperatura promedio anual en superficie es de $25,2{ }^{\circ} \mathrm{C}$ y la profundidad del Agua Subtropical (según isobata de $22{ }^{\circ} \mathrm{C}$ ) se encuentra a $85 \mathrm{~m}$ (Rueda-Roa, 2012).

En el periodo 1994-2009, al oriente de la cuenca Cariaco, el promedio de la temperatura (diciembre-julio) fue $24,86 \pm 1,03{ }^{\circ} \mathrm{C}$ (Lorenzoni et al., 2017). En escala decenal, la temperatura superficial ha aumentado $\sim 1,0 \pm 0,14{ }^{\circ} \mathrm{C}$ (Taylor et al., 2012; Astor et al., 2014); en el golfo de Cariaco (2014-enero 2015) varió entre $20,1-29,1^{\circ} \mathrm{C}$ (CalvoTrujillo et al., 2018). Recientemente, mediante información satelital y datos in situ, se cita que a mediados de año (junioagosto) se detecta una surgencia que es más cálida $\left(\sim 1-2^{\circ} \mathrm{C}\right)$ comparada con la de los primeros meses (Rueda-Roa et al., 2018). En la Tabla 1 se observan valores obtenidos en superficie.

Intensificación de las surgencias por el calentamiento global. Es pertinente hacer mención al debatido planteamiento sobre la intensificación de las surgencias propuesto en la última década del siglo XX. La hipótesis planteada es que, por causa de los gases invernadero, el calentamiento global aumenta el gradiente de temperatura entre tierra y océano e intensifica los gradientes de presión, lo que podría acentuar la tensión del viento a lo largo de las costas e intensificar las surgencias de agua en los límites orientales de los principales océanos mundiales (Bakun, 1990). Son llamadas "áreas EBUE” (Eastern Boundary Upwelling Ecosystems), de las cuales se constituyen como principales las de Humboldt, Bengala, California y Canarias, que aportan $>20 \%$ de las pesquerías mundiales (Pauly y Christensen, 1995). Su monitoreo es importante por la respuesta de las pesquerías al calentamiento global (Cheung et al., 2013; Payne, 2013).

La intensificación de las surgencias tiene estudios que la verifican (Bakun et al., 2010; Cropper et al., 2014; Sydeman et al., 2014; Oerder et al., 2015; Wang et al., 2015), pudiendo causar cambios en la biota marina (Chávez y Messié, 2009; Sydeman et al., 2014). Otros estudios la cuestionan (Barton et al., 2013; Black et al., 2014). La hipótesis se planteó hace dos décadas y en los últimos años, por el calentamiento global actual, ha aumentado el interés en el tema, pero todavía no hay consenso (Gómez-Letona et al., 2017). Al parecer, por el aumento de vientos favorables, se surface. This phenomenon is appreciated until May. From August to October, the surface water is warm $\left(>28^{\circ} \mathrm{C}\right)$ and of lower salinity (36.3), coinciding with the rainy season (Müller-Karger et al., 2004). Also, based on images (19992008), it is mentioned that, in the Venezuelan upwelling (east of $68^{\circ} \mathrm{W}$ ), the average annual surface temperature was $25.2^{\circ} \mathrm{C}$ and the Subtropical Water depth (according to isobath $22{ }^{\circ} \mathrm{C}$ ) is at $85 \mathrm{~m}$ (Rueda-Roa, 2012).

In the period 1994-2009, east of the Cariaco basin, the average temperature (December-July) was $24.86 \pm$ $1.03{ }^{\circ} \mathrm{C}$ (Lorenzoni et al., 2017). On a ten-year scale, the surface temperature has increased $\sim 1.0 \pm 0.14{ }^{\circ} \mathrm{C}$ (Taylor et al., 2012; Astor et al., 2014); in the Gulf of Cariaco (2014-January 2015) it varied between $20.1-29.1^{\circ} \mathrm{C}$ (CalvoTrujillo et al., 2018). Recently, through satellite information and in situ data, it is mentioned that in the middle of the year (June-August) an upwelling is detected, which is warmer $\left(\sim 1-2{ }^{\circ} \mathrm{C}\right)$ compared to that of the first months (Rueda-Roa et al., 2018). In Table 1, values obtained on the surface are observed.

\section{Intensification of upwellings due to global}

warming. It is pertinent to mention the debated approach on the intensification of upwellings proposed in the last decade of the 20th century. The hypothesis is that, due to greenhouse gases, global warming increases the temperature gradient between land and ocean and intensifies pressure gradients, which could accentuate wind stress along the coasts and intensify upwelling of water in the eastern limits of the major world oceans (Bakun, 1990). They are called "EBUE areas" (Eastern Boundary Upwelling Ecosystems), of which Humboldt, Bengal, California and the Canary Islands are the main ones, which contribute $>20 \%$ of the world's fisheries (Pauly and Christensen, 1995). Its monitoring is important for the response of fisheries to global warming (Cheung et al., 2013; Payne, 2013).

The intensification of upwellings has studies that verify it (Bakun et al., 2010; Cropper et al., 2014; Sydeman et al., 2014; Oerder et al., 2015; Wang et al., 2015) and can cause changes in marine biota (Chávez and Messié, 2009; Sydeman et al., 2014). Other studies question it (Barton et al., 2013; Black et al., 2014). The hypothesis was raised two decades ago and in recent years, due to current global warming, interest in the subject has increased, but there is still no consensus (Gómez-Letona et al., 2017). Apparently, due to the increase in favorable winds, upwellings have intensified to the north of $21^{\circ} \mathrm{N}$, but south of $19^{\circ} \mathrm{N}$ they have decreased due to unfavorable winds that propitiate 
han intensificado las surgencias al norte de $21^{\circ} \mathrm{N}$, pero al sur de $19^{\circ} \mathrm{N}$ han disminuido por vientos desfavorables que propician el hundimiento del agua superficial (Cropper et al., 2014). Es posible que esta situación pueda ocurrir en las surgencias del Caribe sur, localizadas entre 10,2 y $12,5^{\circ} \mathrm{N}$.

Por lo anterior, es apropiado referirse a la crisis pesquera de la sardina venezolana, que inició en 2005 y se mantuvo alrededor de una década (Gómez, 2018a). Se menciona que la crisis fue ocasionada por la sobrepesca de sardina en 2003 y 2004 (Rueda-Roa, 2012; Mendoza, 2015), cuando las capturas anuales fueron 200232 t. Sin embargo, las diversas estimaciones hidroacústicas coincidían en la existencia de 850000 t explotables (Gerlotto y Ginés, 1988; Stromme y Saetersdal, 1989; Cárdenas y Achury, 2002) y de una biomasa hasta de 1300000 t (Cárdenas, 2003). Varios estudios también indicaron que la sardina estaba siendo subexplotada (Freón y Mendoza, 2003; Freón et al., 2003) y/o estable (Guzmán y Gómez, 2000). En contraposición, se ha planteado que la principal causa de la actual fluctuación del recurso sardinero tiene que ver más bien con la disminución de la fertilidad acuática regional. Es así que desde 2005 las surgencias han sido débiles (Gómez et al., 2012; Gómez y Barceló, 2014), la biomasa de fitoplancton ha disminuido notablemente (Gómez et al., 2014) y es probable que la causa de la crisis sardinera sea un cambio de régimen ecológico (Gómez, 2018b, 2019), lo que afectó servicios del ecosistema como la pesca. Así mismo, se mencionó el debilitamiento de los alisios por la migración del centro de alta presión de Azores hacia el norte (Taylor et al., 2012). Esto repercute en la menor intensidad de la surgencia venezolana.

\section{NUTRIENTES DEL AGUA QUE AFLORA}

Guajira de Colombia. La concentración máxima de nitrato fue de $2-3 \mu \mathrm{mol} / \mathrm{L}$, valor inferior al de otras áreas de surgencia, como Perú y el noroccidente de África (Corredor, 1979). En la Guajira, un mecanismo para el enriquecimiento de nutrientes son las partículas de arena transportadas por el viento desde áreas desérticas, como se observa en fotos satelitales. Esto también ocurre en California y el noroccidente de África (Andrade y Barton, 2005). Por datos de nutrientes (enero-julio) obtenidos de atlas climatológicos WOA09 y cruceros oceanográficos (junio y octubre), las mayores concentraciones de nitrato se encuentran en profundidades superiores a $150 \mathrm{~m}$ y aumentan de enero a julio a nivel del estrato de fondo (150-500 m). En the subsidence of surface water (Cropper et al., 2014). It is possible that this situation could occur in upwellings in the southern Caribbean, located between 10.2 and $12.5^{\circ} \mathrm{N}$.

Therefore, it is appropriate to refer to the Venezuelan sardine fishing crisis, which began in 2005 and lasted for about a decade (Gómez, 2018a). It is mentioned that the crisis was caused by overfishing of sardines in 2003 and 2004 (Rueda-Roa, 2012; Mendoza, 2015), when the annual catches were 200232 t. However, the various hydroacoustic estimates agreed on the existence of 850000 t exploitable (Gerlotto and Ginés, 1988; Stromme and Saetersdal, 1989; Cárdenas and Achury, 2002) and a biomass of up to $1300000 \mathrm{t}$ (Cárdenas, 2003). Several studies also indicated that the sardine was being underexploited (Freón and Mendoza, 2003; Freón et al., 2003) and/or stable (Guzmán and Gómez, 2000). In contrast, it has been suggested that the main cause of the current fluctuation of the sardine resource has to do more with the decrease in regional aquatic fertility because since 2005 upwellings have been weak (Gómez et al., 2012; Gómez and Barceló, 2014), the phytoplankton biomass has decreased notably (Gómez et al., 2014) and it is likely that the cause of the sardine crisis is a change in the ecological regime (Gómez, 2018b, 2019), which affected ecosystem services such as the fishing. Likewise, the weakening of the trade winds due to the migration of the high pressure center of the Azores to the north was mentioned (Taylor et al., 2012). This affects the lower intensity of the Venezuelan upwelling.

\section{NUTRIENTS OF THE UPWELLED WATER}

Colombian Guajira. The maximum nitrate concentration was $2-3 \mu \mathrm{mol} / \mathrm{L}$, a lower value than in other upwelling areas, such as Peru and northwestern Africa (Corredor, 1979). In La Guajira, a mechanism for the enrichment of nutrients is the sand particles carried by the wind from desert areas, as observed in satellite photos. This is also the case in California and Northwest Africa (Andrade and Barton, 2005). Based on nutrient data (January-July) obtained from WOA09 climatological atlases and oceanographic cruises (June and October), the highest concentrations of nitrate are found at depths greater than $150 \mathrm{~m}$ and increase from January to July at the level of the bottom layer (150-500 m). In October, they fall to the lowest values (Dueñas-Lagos et al., 2017).

It is mentioned that the characteristics of the Colombian Caribbean, from the physicochemical point 
octubre, descienden hasta los valores más bajos (DueñasLagos et al., 2017).

Se menciona que las características del Caribe colombiano, desde el punto de vista físicoquímico, no se han abordado, por lo cual se analizaron dos transectos, uno longitudinal sobre $12^{\circ} \mathrm{N}$ y otro latitudinal en $74^{\circ} \mathrm{W}$ (Murcia-Riaño et al., 2017). En el longitudinal, en febrero, la capa de mezcla tiene $50 \mathrm{~m}$ de profundidad (temperatura promedio: $25,5 \pm 0,49^{\circ} \mathrm{C}$; salinidad: $36,4 \pm 0,10$ ); en los nutrientes no hay aumento: el promedio de fosfatos, nitrato y silicatos fue de $0,07,1,73$ y $2,3 \mu \mathrm{mol} / \mathrm{L}$, respectivamente. Estos valores evidencian que no hay un pulso de alta concentración de nutrientes que provenga desde capas más profundas. En julio la profundidad de la capa de mezcla es menor $\left(30 \mathrm{~m}\right.$ ) y la temperatura aumentó $1,3{ }^{\circ} \mathrm{C}$ (promedio: $26,8 \pm 0,39^{\circ} \mathrm{C}$ ). Con esto, se estima que ocurre un segundo pulso de surgencia, pero no se evidencia que aguas con menor temperatura lleguen desde la subsuperficie; sin embargo, se detecta un pulso de alta concentración de nitratos y silicatos provenientes del oriente. En noviembre, aguas de la contracorriente de Colombia (temperatura: $27,7 \pm 0,27^{\circ} \mathrm{C}$; salinidad: $35,8 \pm 0,35$ ) llegan a la Guajira y en el transecto $\left(12^{\circ} \mathrm{N}\right)$ los silicatos tienen alta concentración con valores hasta de $10 \mu \mathrm{mol} / \mathrm{L}$ (Murcia-Riaño et al., 2017). Previamente se citó que en la plataforma centroamericana las aguas son oligotróficas (Aguirre y Salmerón, 2015; Brenes et al., 2017). Se ha discutido que en la Guajira aflora SUW, la cual se localiza a 100-200 m de profundidad (Hernández y Joyce, 2000); no obstante, se sugiere que las aguas que abastecen la surgencia pueden estar influenciadas por el giro Panamá-Colombia (corriente del Darién), que en la región fluye por debajo hasta $100 \mathrm{~m}$ de profundidad (Andrade et al., 2003). Este origen determinaría la baja cantidad de nutrientes del agua que emerge (Paramo et al., 2011).

Oriente de Venezuela. En el agua que aflora el nitrato tiene una concentración entre 6-8 $\mu \mathrm{mol} / \mathrm{L}$ (Richards, 1960; Bonilla et al., 1993); entre Margarita y Araya se habla de $14,8 \mu \mathrm{mol} / \mathrm{L}$ (Ballester, 1965), y en la fosa y el golfo de Cariaco de 1,2 $\mu \mathrm{mol} / \mathrm{L}$ (Okuda, 1978; Mandelli y Ferraz, 1982). El nitrito varía de 0,53 a $1 \mu \mathrm{mol} / \mathrm{L}$ en el golfo de Cariaco (Kato, 1961; Mandelli y Ferraz, 1982) y de 0,59 a $1,74 \mu \mathrm{mol} / \mathrm{L}$ en las islas de Coche, Cubagua y el sur de Margarita en 2004-2005 (Gómez et al., 2008). Se mencionan concentraciones de amonio entre 6 y $17 \mu \mathrm{mol} / \mathrm{L}$ en los primeros $50 \mathrm{~m}$ del golfo y la fosa de Cariaco (Kato, 1961). También hasta de 2,4 $\mu \mathrm{mol} / \mathrm{L}$ (Richards y Vaccaro, 1956; Mandelli y Ferraz, 1982) y de 3,0 a 5,5 $\mu \mathrm{mol} / \mathrm{L}$ entre Araya of view, have not been addressed; therefore two transects were analyzed, one longitudinal over $12^{\circ} \mathrm{N}$ and the other latitudinal at $74{ }^{\circ} \mathrm{W}$ (Murcia-Riaño et al., 2017). In the longitudinal one, in February, the mixed layer is $50 \mathrm{~m}$ deep (average temperature: $25.5 \pm 0.49{ }^{\circ} \mathrm{C}$; salinity: 36.4 \pm 0.10 ); There is no increase in nutrients: the average of phosphates, nitrate and silicates was $0.07,1.73$ and 2.3 $\mu \mathrm{mol} / \mathrm{L}$, respectively. These values show that there is not a pulse of high concentration of nutrients that comes from deeper layers. In July, the depth of the mixed layer is less $\left(30 \mathrm{~m}\right.$ ) and the temperature increased $1.3{ }^{\circ} \mathrm{C}$ (average: 26.8 $\pm 0.39^{\circ} \mathrm{C}$ ) With this, it is estimated that a second upwelling pulse occurs, but it is not evident that waters with lower temperatures arrive from the subsurface; however, a pulse of high concentration of nitrates and silicates from the east is detected. In November, waters from the Colombia Countercurrent (temperature: $27.7 \pm 0.27^{\circ} \mathrm{C}$; salinity: 35.8 $\pm 0.35)$ reach La Guajira and in the transect $\left(12^{\circ} \mathrm{N}\right)$ the silicates have a high concentration with values up to 10 $\mu \mathrm{mol} / \mathrm{L}$ (Murcia-Riaño et al., 2017). Previously, it was mentioned that in the Central American shelf the waters are oligotrophic (Aguirre and Salmerón, 2015; Brenes et al., 2017). It has been argued that Subtropical Subsurface Water outcrops in La Guajira, which is located 100-200 m deep (Hernández and Joyce, 2000); however, it is suggested that the waters supplying the upwelling may be influenced by the Panama-Colombia gyre (Darien current), which in the region flows below up to $100 \mathrm{~m}$ deep (Andrade et al., 2003). This origin would determine the low amount of nutrients in the water that emerges (Paramo et al., 2011).

Eastern Venezuela. In the upwelling water, nitrate has a concentration between 6-8 $\mu \mathrm{mol} / \mathrm{L}$ (Richards, 1960; Bonilla et al., 1993); $14.8 \mu \mathrm{mol} / \mathrm{L}$ between Margarita and Araya (Ballester, 1965), and $1.2 \mu \mathrm{mol} / \mathrm{L}$ in the Cariaco Trench and Gulf (Okuda, 1978; Mandelli and Ferraz, 1982). Nitrite ranges from 0.53 to $1 \mu \mathrm{mol} / \mathrm{L}$ in the Gulf of Cariaco (Kato, 1961; Mandelli and Ferraz, 1982) and from 0.59 to $1.74 \mu \mathrm{mol} / \mathrm{L}$ in the islands of Coche, Cubagua and the south de Margarita in 2004-2005 (Gómez et al., 2008). Ammonium concentrations between 6 and $17 \mu \mathrm{mol} / \mathrm{L}$ are mentioned in the first $50 \mathrm{~m}$ of the gulf and the Cariaco Trench (Kato, 1961). Also up to $2.4 \mu \mathrm{mol} / \mathrm{L}$ (Richards and Vaccaro, 1956; Mandelli and Ferraz, 1982) and from 3.0 to $5.5 \mu \mathrm{mol} / \mathrm{L}$ between Araya and Margarita (Ballester, 1965). On the island Cubagua and the southeast of Margarita 2.21 and $2.89 \mu \mathrm{mol} / \mathrm{L}$ are cited in the first $20 \mathrm{~m}$ depth (Gómez and Chanut, 1988, 1993; Gómez et al., 2008). In the 2003- 
y Margarita (Ballester, 1965). En la isla Cubagua y el sureste de Margarita, en los primeros $20 \mathrm{~m}$ de profundidad se citan entre 2,21 y 2,89 $\mu \mathrm{mol} / \mathrm{L}$ (Gómez y Chanut, 1988, 1993; Gómez et al., 2008). En las surgencias de 2003-2004, la concentración promedio fue de 2,04 y 2,18 $\mu \mathrm{mol} / \mathrm{L}$ al oriente de Margarita (Gómez y Barceló, 2014). Se menciona que las concentraciones de amonio son bajas cuando el nitrito y el nitrato son altos (Gómez y Chanut, 1993) y se comenta que, en el área, el nutriente limitante para las microalgas puede ser el amonio (Salazar-Gómez et al. 2011; Gómez et al., 2012). En la década 2003-2012, el amonio tuvo las mayores concentraciones durante 2003 en Margarita (Figura 2). Del fosfato, el ámbito en superficie es de 0,15 a $0,53 \mu \mathrm{mol} / \mathrm{L}$ (Richards, 1960; Hulburt, 1966; Okuda et al., 1969; Okuda, 1981; Ferraz, 1989). También se citan entre 1-1,5 $\mu \mathrm{mol} / \mathrm{L}$ (Kato, 1961) y 1,63-3,37 $\mu \mathrm{mol} / \mathrm{L}$ (Ballester, 1965) y en la estación Cariaco $<0,3 \mu \mathrm{mol} / \mathrm{L}$ (Astor et al., 2004). En Margarita, durante las surgencias fuertes de 2003 y 2004, se determinaron promedios de hasta $0,97 \mu \mathrm{mol} / \mathrm{L}$ (Gómez y Barceló, 2014). En la pluma del Orinoco (oriente de isla Granada), el amonio y la urea tuvieron una concentración de 0,094 y $0,347 \mu \mathrm{mol} / \mathrm{L}$, respectivamente; el fosfato y nitrato son indetectables (John et al., 2012). En la Tabla 1 se muestran cifras citadas en superficie.

Según los valores de la hidrografía y la limitada información sobre los nutrientes, mientras no se posean
2004 upwellings, the average concentration was 2.04 and $2.18 \mu \mathrm{mol} / \mathrm{L}$ east of Margarita (Gómez and Barceló, 2014). It is mentioned that ammonium concentrations are low when nitrite and nitrate are high (Gómez and Chanut, 1993) and it was commented that, in the area, the limiting nutrient for microalgae may be ammonium (Salazar-Gómez et al. 2011; Gómez et al., 2012). In the decade 2003-2012, ammonia had the highest concentrations during 2003 in Margarita (Figure 2). For phosphate, the surface range is 0.15 to 0.53 $\mu \mathrm{mol} / \mathrm{L}$ (Richards, 1960; Hulburt, 1966; Okuda et al., 1969; Okuda, 1981; Ferraz, 1989). They are also cited between 1-1.5 $\mu \mathrm{mol} / \mathrm{L}$ (Kato, 1961) and 1.63-3.37 $\mu \mathrm{mol} / \mathrm{L}$ (Ballester, 1965 ) and in the Cariaco station $<0.3 \mu \mathrm{mol} / \mathrm{L}$ (Astor et al., 2004). In Margarita, during the strong upwellings of 2003 and 2004, averages of up to $0.97 \mu \mathrm{mol} / \mathrm{L}$ were determined (Gómez and Barceló, 2014). In the Orinoco plume (eastern Granada Island), ammonium and urea had a concentration of 0.094 and $0.347 \mu \mathrm{mol} / \mathrm{L}$, respectively; phosphate and nitrate are undetectable (John et al., 2012). Table 1 shows figures cited on the surface.

According to the values of the hydrography and the limited information on nutrients, while there are no concrete data with temporary permanence, at least of medium range, the origin of the water that emerges in the Colombian Guajira is still not clear because some authors affirm oligotrophic waters arise. In the Venezuelan upwelling, the phenomenon

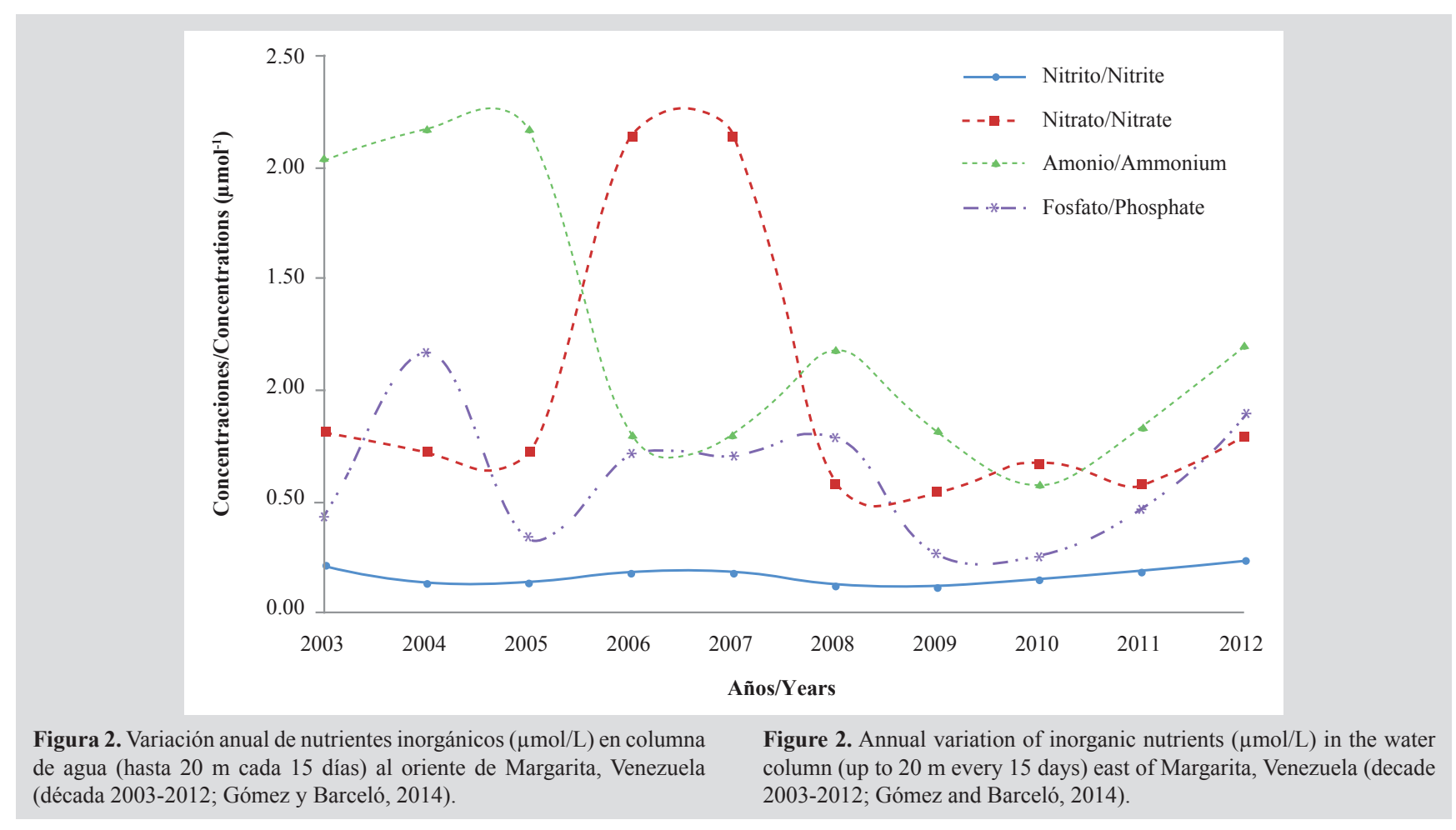


datos concretos con permanencia temporal, por lo menos, de mediano alcance, aún no es claro el origen del agua que aflora en la Guajira colombiana porque algunos autores afirman que surgen aguas oligotróficas. En la surgencia venezolana, el fenómeno presenta grandes variaciones temporales, pero es claro que afloran Aguas Subtropicales con mayores concentraciones de nutrientes inorgánicos que en la colombiana.

\section{RÍOS}

Guajira de Colombia. En el Caribe suroriental colombiano (departamentos de La Guajira y oriente de Magdalena), se cita la presencia de 13 ríos pequeños (Gaira, Manzanares, Piedras, Mendihuaca, Guachaca, Buritaca, Don Diego, Palomino, Jerez, Cañas, Ancho, Tapias y Ranchería), los cuales, en total, descargan $143 \mathrm{~m}^{3} / \mathrm{s}$ y $4,51 \mathrm{~km}^{3} /$ año (Beier et al., 2017). En el suroccidente de la Guajira, en Barranquilla (Bocas de Ceniza), se encuentra la desembocadura del río más importante de Colombia, el Magdalena, que tiene una longitud de $1550 \mathrm{~km}$ y una cuenca de $257438 \mathrm{~km}^{2}$. Arroja un promedio de $7200 \mathrm{~m}^{3} / \mathrm{s}\left(228 \mathrm{~km}^{3}\right.$ de agua anual) con una carga de sedimentos de $114 \times 10^{6} \mathrm{t} /$ año. Las descargas pico ocurren entre octubre y diciembre (Restrepo y Kjerfve, 2000). Entre 1978 y 2010, los ríos que drenan en el Caribe colombiano descargaron en promedio $146,3 \times 10^{6}$ t/año de sedimentos. De ellos, el Magdalena aportó 97 \% (Restrepo-López et al., 2015). Entre 19901999, se citan descargas de hasta $169 \pm 73 \times 10^{6}$ t/año (Higgins et al., 2016), que son fuente de nutrientes para el Caribe colombiano, especialmente la zona oceánica de la Guajira (Murcia-Riaño et al., 2017).

Durante la época seca, la pluma del Magdalena se desplaza hacia el SW por los vientos alisios (Andrade y Thomas, 1988; Molina et al., 1996) y causa turbidez en la bahía Amansaguapos, donde la plataforma continental tiene $35 \mathrm{~km}$ y fondos de arena fina (Pinzón et al., 1998). El núcleo de surgencia en la Guajira y la desembocadura del Magdalena están distanciados unos $500 \mathrm{~km}$; en fotografías satelitales, se observan parches de pigmentos provenientes del río. El agua tiene temperatura alta $\left(35^{\circ} \mathrm{C}\right)$ y la corriente fluye al occidente, lo que evita que sus aguas entren al sistema surgente (Andrade y Barton, 2005). Muestreos del mesozooplancton hasta $1000 \mathrm{~m}$ indican que la estructura comunitaria en la Guajira tiene diferencias con la pluma del Magdalena e islas del Rosario (Gutiérrez-Salcedo, 2011). En imágenes y por observaciones in situ en el Cabo presents large temporal variations, but it is clear that Subtropical Waters with higher concentrations of inorganic nutrients emerge than in the Colombian upwelling.

\section{RIVERS}

Colombian Guajira. In the southeastern Colombian Caribbean (departments of La Guajira and eastern Magdalena) there are 13 small rivers (Gaira, Manzanares, Piedras, Mendihuaca, Guachaca, Buritaca, Don Diego, Palomino, Jerez, Cañas, Ancho, Tapias and Ranchería), which, in total, discharge $143 \mathrm{~m}^{3} / \mathrm{s}$ and 4.51 $\mathrm{km}^{3} /$ year (Beier et al., 2017). At the southwestern of La Guajira, in Barranquilla (Bocas de Ceniza), is the mouth of the most important river in Colombia, the Magdalena, which has a length of $1550 \mathrm{~km}$ and a basin of 257438 $\mathrm{km}^{2}$. It discharges an average of $7200 \mathrm{~m}^{3} / \mathrm{s}\left(228 \mathrm{~km}^{3}\right.$ of water per year) with a sediment load of $114 \times 10^{6} \mathrm{t} /$ year. Peak discharges occur between October and December (Restrepo and Kjerfve, 2000). Between 1978 and 2010, the rivers that drain into the Caribbean Colombian downloaded on average $146.3 \times 106$ t/year of sediment. Of them, Magdalena contributed 97 \% (Restrepo-López et al., 2015). Between 1990-1999, discharges of up to $169 \pm 73 \times 106 \mathrm{t} /$ year are cited (Higgins et al., 2016), which are a source of nutrients for the Colombian Caribbean, especially the oceanic zone of La Guajira (Murcia-Riaño et al., 2017).

During the dry season, the Magdalena plume moves to the SW by the trade winds (Andrade and Thomas, 1988; Molina et al., 1996) and causes turbidity in the Amansaguapos Bay, where the continental shelf is $35 \mathrm{~km}$ wide and bottoms of fine sand (Pinzón et al., 1998). The upwelling nucleus in La Guajira and the mouth of the Magdalena are about $500 \mathrm{~km}$ apart; in satellite photographs, patches of pigments from the river are observed. The water has a high temperature $\left(35^{\circ} \mathrm{C}\right)$ and the current flows west, which prevents its waters from entering the upwelling system (Andrade and Barton, 2005). Mesozooplankton samplings up to $1000 \mathrm{~m}$ indicate that the community structure in La Guajira differs from the Magdalena plume and Rosario Islands (Gutiérrez-Salcedo, 2011). In images and by observations in situ at Cabo de la Vela, warm and fresh waters of Lake Maracaibo are evident; the upwelling is affected by these waters that reach up to $50 \mathrm{~m}$ deep. The plume from Lake Maracaibo discharges into the Gulf of Venezuela, where it turns to the west and joins the Guajira, thereby becoming a mechanism to enrich the 
de la Vela, son evidentes aguas cálidas y dulces del lago de Maracaibo; la surgencia se ve afectada por estas aguas que llegan hasta $50 \mathrm{~m}$ de profundidad. La pluma del lago de Maracaibo descarga en el golfo de Venezuela, donde gira hacia el occidente y se incorpora a la Guajira, con lo que se convierte en un mecanismo para enriquecer la región (Andrade y Barton, 2005), aunque es posible que las aguas cálidas y menos salinas provengan de la contracorriente del Darién. Mediante imágenes y modelos numéricos se plantea que el flujo del lago de Maracaibo hacia el golfo de Venezuela solo es posible cuando disminuyen los vientos alisios (Gómez et al., 2017) y la clorofila varía entre 0,1 y $5,2 \mathrm{mg} / \mathrm{m}^{3}$ (Rodríguez y Varela, 1987).

Oriente de Venezuela. La surgencia intensa ocurre sobre la plataforma continental, la cual recibe la intrusión de agua estuarina proveniente del golfo de Paria en su extremo oriental. La intrusión es descargada principalmente por dos caños navegables (Mánamo y Macareo) del río Orinoco y entran al Caribe por la boca del Dragón, entre la península de Paria y la isla de Trinidad. Durante los meses de descargas máximas, estas aguas afectan toda la plataforma nororiental de Venezuela (Aparicio y Contreras, 2003), por lo cual el Orinoco adquiere mayor importancia, a pesar de que también desemboca en el Atlántico a través del enorme delta, que alcanza $300 \mathrm{~km}$ de longitud, grandes caños principales y numerosos afluentes.

El Orinoco tiene una longitud de $2101 \mathrm{~km}$ y drena aguas de una cuenca de $1250000 \mathrm{~km}^{2}$. Su gasto varía entre 30000 y $80000 \mathrm{~m}^{3} / \mathrm{s}$ en septiembre-octubre, con un promedio anual de $36000 \mathrm{~m}^{3} / \mathrm{s}$ (Rabinovich y Novoa, 1982; Meade et al., 1983; Lewis y Saunders, 1989; Monente, 1990), y descarga al mar alrededor de $90 \times 10^{6} \mathrm{t} /$ año de material suspendido (Blough et al., 1993). Las aguas salobres tienen altas concentraciones de silicato y fósforo orgánico, pero son pobres en nitrato y fosfato (Richards, 1960) y están desprovistas de nitratos (Bonilla et al., 1993). La influencia del grandioso Orinoco se nota desde julio hasta finales de año (Ljoen y Herrera, 1965; Febres, 1974; Okuda et al., 1974). Las descargas máximas ocurren en agostoseptiembre (Aparicio, 2003). Al suroriente de la plataforma, la capa de baja salinidad tiene una altura de $15 \mathrm{~m}$ (Okuda et al., 1974) y se desplaza con una velocidad de $15-33 \mathrm{~cm} / \mathrm{s}$ (Moore y Todd, 1993); en septiembre-octubre, la capa afecta un área superior a $300000 \mathrm{~km}^{2}$ (Müller-Karger et al., 1989; Blough et al., 1993).

En el segundo semestre del año, las aguas del Orinoco afectan la isla Margarita, situada a $220 \mathrm{~km}$ de la region (Andrade and Barton, 2005), although it is possible that warm waters and less saline come from the Darien Countercurrent. Using images and numerical models, it is suggested that the flow from Lake Maracaibo to the Gulf of Venezuela is only possible when the trade winds decrease (Gómez et al., 2017) and chlorophyll varies between 0.1 and $5.2 \mathrm{mg} / \mathrm{m}^{3}$ (Rodríguez and Varela, 1987).

Eastern Venezuela. The intense upwelling occurs on the continental shelf, which receives the intrusion of estuarine water from the Gulf of Paria at its eastern end. The intrusion is discharged mainly by two navigable channels (Mánamo and Macareo) of the Orinoco River and enters the Caribbean through the Boca del Dragón, between the Paria peninsula and the island of Trinidad. During the months of maximum discharges, these waters affect the entire northeastern platform of Venezuela (Aparicio and Contreras, 2003), for which the Orinoco acquires greater importance, despite the fact that it also empties into the Atlantic through the enormous delta, which reaches 300 $\mathrm{km}$ in length, large main streams and numerous tributaries.

The Orinoco is $2101 \mathrm{~km}$ long and drains waters from a $1250000 \mathrm{~km}^{2}$ basin. Its flow varies between 30000 and $80000 \mathrm{~m}^{3} / \mathrm{s}$ in September-October, with an annual average of $36000 \mathrm{~m}^{3} / \mathrm{s}$ (Rabinovich and Novoa, 1982; Meade et al., 1983; Lewis and Saunders, 1989; Monente, 1990 ), and discharge to the sea around $90 \times 10^{6}$ t/year of suspended material (Blough et al., 1993). Brackish waters have high concentrations of silicate and organic phosphorus, but are poor in nitrate and phosphate (Richards, 1960) and are devoid of nitrates (Bonilla et al., 1993). The influence of the great Orinoco is noticeable from July to the end of the year (Ljoen and Herrera, 1965; Febres, 1974; Okuda et al., 1974). The maximum discharges occur in AugustSeptember (Aparicio, 2003). To the southeast of the shelf, the low-salinity layer is $15 \mathrm{~m}$ high (Okuda et al., 1974) and moves with a speed of 15-33 cm/s (Moore and Todd, 1993); in September-October, the layer affects an area greater than $300000 \mathrm{~km}^{2}$ (Müller-Karger et al., 1989; Blough et al., 1993).

In the second half of the year, the waters of the Orinoco affect Margarita Island, located $220 \mathrm{~km}$ from the Dragon's Mouth. Considering that the Caribbean current has a speed of $50 \mathrm{~cm} / \mathrm{s}$ in October (Gordon, 1967), these waters would take five days to arrive (Gómez, 1996), which would explain their presence to the north of the island (Müller-Karger et al., 1989; Bonells et al., 1990; Müller-Karger and Varela, 1990) and by salinity of 15.95 in 
boca del Dragón. Considerando que la corriente del Caribe tiene una velocidad de $50 \mathrm{~cm} / \mathrm{s}$ en octubre (Gordon, 1967), estas aguas tardarían cinco días en llegar (Gómez, 1996), lo que explicaría su presencia al norte de la isla (Müller-Karger et al., 1989; Bonells et al., 1990; Müller-Karger y Varela, 1990) y salinidades de hasta 15,95 en varias localidades. También afecta el oriente y sur de Margarita por valores de 29,9-34,5 en otros lugares y de 29,55 en isla Cubagua (Gómez et al., 2008). Estudios intensivos verificaron que durante julio-diciembre, al sur de Margarita, las aguas en superficie tienen menor salinidad (Gómez y Chanut, 1993). Sin embargo, se afirma que el grueso de las aguas del Orinoco se dispersa al norte de la fosa de Cariaco y que la pequeña pero mensurable disminución de salinidad durante la época de lluvias se debe a ríos locales (Tuy, Neverí, Manzanares) y no al río Orinoco (Müller-Karger et al., 1989; MüllerKarger y Varela, 1990). Este no es el caso del oriente y sur de Margarita y de las islas de Coche y Cubagua.

En el Caribe suroriental, es muy importante la materia orgánica disuelta y coloreada que introduce el río Orinoco. Se estima que descarga $2,5 \times 10^{12} \mathrm{~g} /$ año $(\sim 1 \% \mathrm{del}$ carbono disuelto en los océanos) y también grandes cantidades de material suspendido $(\sim 80 \mathrm{mg} / \mathrm{L})$ y disuelto $(\sim 34 \mathrm{mg} / \mathrm{L})$ (Blough et al., 1993). Por fotografías, se determina que la extensiva coloración de la pluma corresponde a materia orgánica disuelta y coloreada (Odriozola et al., 2007), en lugar de ser una pluma altamente productiva de nutrientes (López et al., 2013). Se reconfirma su carencia de nitratos (Bonilla et al., 1993), pero contiene valores altos de amonio y urea que favorecen el fitoplancton (John et al., 2012). La fotomineralización de la materia orgánica disuelta (coloreada) en amonio es la fuente de nitrógeno para el fitoplancton, que incrementa su biomasa (López et al., 2013). Estos nutrientes, detectados hasta $1000 \mathrm{~km}$ de su delta (Morell y Corredor, 2001), tienen un efecto fisiológico, que aumenta el potencial fotosintético observado en las aguas influenciadas por la pluma del Orinoco. Al norte de Trinidad, en sedimentos superficiales, el ensamble de foraminíferos planctónicos indica mayor influencia de la pluma del Orinoco que de la surgencia (Wilson y Hayek, 2019).

Cuando disminuye la descarga del río, su impacto en la región es menor por la reducción espacial de la pluma, lo cual se refleja en las bajas estimaciones de producción primaria, como lo verifica su variabilidad temporal (20022011) obtenida del color del océano. En 2005, se registraron las estimaciones más bajas (López et al., 2013), coincidentes con la sequía más intensa en la región amazónica en los localities. It also affects the east and south of Margarita by values of 29.9-34.5 in other places and 29.55 in Cubagua Island (Gómez et al., 2008). Intensive studies verified that during July-December, south of Margarita, surface waters have lower salinity (Gómez and Chanut, 1993). However, it is stated that the bulk of the Orinoco waters are dispersed north of the Cariaco Trench and that the small but measurable decrease in salinity during the rainy season is due to local rivers (Tuy, Neverí, Manzanares) and not to the Orinoco River (Müller-Karger et al., 1989; Müller-Karger and Varela, 1990). This is not the case in the east and south of Margarita and the islands of Coche and Cubagua.

In the southeastern Caribbean, the dissolved and colored organic matter introduced by the Orinoco River is very important. It is estimated to discharge $2.5 \times 10^{12}$ g/year ( $\sim 1 \%$ of dissolved carbon in the oceans) and also large amounts of suspended ( $\sim 80 \mathrm{mg} / \mathrm{L})$ and dissolved ( 34 $\mathrm{mg} / \mathrm{L}$ ) material (Blough et al., 1993). From photographs, it is determined that the extensive coloration of the plume corresponds to dissolved and colored organic matter (Odriozola et al., 2007) instead of being a highly productive plume of nutrients (López et al., 2013). Nitrate deficiency is reconfirmed (Bonilla et al., 1993), but it contains high values of ammonium and urea that favor phytoplankton (John et al., 2012). The photomineralization of dissolved (colored) organic matter in ammonia is the source of nitrogen for phytoplankton, which increases their biomass (López et al., 2013). These nutrients have a physiological effect, which increases the photosynthetic potential observed in waters influenced by the Orinoco plume and are detected up to $1000 \mathrm{~km}$ from its delta (Morell and Corredor, 2001). North of Trinidad, in surface sediments, the assemblage of planktonic foraminifera indicates a greater influence from the Orinoco plume than from the upwelling (Wilson and Hayek, 2019).

When river discharge decreases, its impact on the region is less due to the spatial reduction of the plume, which is reflected in the low estimates of primary production, as verified by its temporal variability (2002-2011) obtained from the color of the ocean. In 2005, the lowest estimates were obtained (López et al., 2013), coinciding with the most intense drought in the Amazon region in the last hundred years, driven by an abnormally warm tropical North Atlantic, which reduced the intensity of the trade winds from the northeast (Marengo et al., 2008).

The Amazon River has a length of $7062 \mathrm{~km}$ and a basin of $7050000 \mathrm{~km}^{2}$; discharges into the Atlantic a volume 
últimos cien años, impulsada por un Atlántico norte tropical anormalmente cálido, que redujo la intensidad de los vientos alisios del noreste (Marengo et al., 2008).

El Amazonas tiene una longitud de $7062 \mathrm{~km}$ y una cuenca de $7050000 \mathrm{~km}^{2}$; descarga al Atlántico un volumen equivalente a $18 \%$ de los ríos del mundo; su flujo medio es de $230000 \mathrm{~m}^{3} / \mathrm{s}$ con un gasto máximo de $300000 \mathrm{~m}^{3} / \mathrm{s}$ en mayo-junio (Goes et al., 2014); $20 \%$ del sílice transportado se exporta, alcanza las Antillas Menores (Edmont y Boyle, 1981) y es verificado en el Caribe oriental (Ljoen y Herrera, 1965). De febrero a mayo, existen corrientes continuas desde Brasil hasta el mar Caribe, que se unen a las aguas del Orinoco en las costas de Venezuela (Müller-Karger y Varela, 1988). La influencia máxima del río ocurre en junio (Hu et al., 2004) y estudios sedimentológicos en la plataforma venezolana confirman la procedencia de partículas desde el Amazonas (Van Andel, 1967; Milliman et al., 1982).

En el Caribe suroriental, la descarga de estos ríos se ve influenciada por las variaciones hidrológicas en el continente, guiadas por los cambios climáticos que causa la traslación anual de la ZCIT. Cuando esta se mueve al sur conlleva el aumento de lluvias al sur del Ecuador y sequías o disminución de lluvias al norte. Sin embargo, causas variadas propician que la reducción de lluvias sobre la cuenca del Orinoco-Amazonas ocurra por lapsos superiores; su evidencia se verifica desde el Holoceno, de acuerdo con récords de la deposición de titanio en los sedimentos de la fosa de Cariaco (Haug et al., 2001) y al extrapolarse al norte de Suramérica. Estos cambios controlan las variaciones de productividad marina en el Caribe oriental y el impacto de los ríos, comprobando conexiones globales con el clima regional (López et al., 2013). En la Guajira, no existe evidencia de los efectos de aguas de grandes ríos que aporten materia orgánica disuelta y coloreada, a diferencia de la surgencia en el oriente de Venezuela, debido al inmenso aporte del río Orinoco y relativamente por el Amazonas.

\section{BIOMASA DE FITOPLANCTON}

Guajira de Colombia. Las estimaciones de clorofila in situ son escasas; la mayoría de valores que se mencionan derivan de imágenes satelitales. Andrade y Barton (2005) citan un máximo de clorofila $a$ de $3 \mathrm{mg} / \mathrm{m}^{3}$, valor comparable al determinado in situ por Corredor (1979). Durante el periodo 2002-2014, entre Santa Marta y el Cabo de la Vela, la clorofila tuvo tendencia positiva $\left(0,05 \mathrm{mg} / \mathrm{m}^{3} /\right.$ año), pero a partir de $\sim 22 \mathrm{~km}$ de la equivalent to $18 \%$ of the world's rivers; its average flow is $230000 \mathrm{~m}^{3} / \mathrm{s}$ with a maximum flow of $300000 \mathrm{~m}^{3} / \mathrm{s}$ in MayJune (Goes et al., 2014); $20 \%$ of the transported silica is exported, reaches the Lesser Antilles (Edmont and Boyle, 1981) and is verified in the eastern Caribbean (Ljoen and Herrera, 1965). From February to May, there are continuous currents from Brazil to the Caribbean Sea, which join the waters of the Orinoco off the coast of Venezuela (MüllerKarger and Varela, 1988). The maximum influence of the river occurs in June (Hu et al., 2004) and sedimentological studies on the Venezuelan shelf confirm the origin of particles from the Amazon (Van Andel, 1967; Milliman et al., 1982).

In the southeastern Caribbean, the discharge of these rivers is influenced by hydrological variations on the continent, guided by climatic changes caused by the annual translation of the ITCZ. When it moves south, it leads to increased rainfall in southern Ecuador and droughts or decreased rainfall in the north. However, various causes produce the reduction of rainfall over the Orinoco-Amazon basin to occur for longer periods; its evidence is verified since the Holocene, according to records of the deposition of titanium in the sediments of the Cariaco Trench (Haug et al., 2001) and when extrapolated to northern South America. These changes control variations in marine productivity in the eastern Caribbean and the impact of rivers, proving global connections with the regional climate (López et al., 2013). In La Guajira, there is no evidence of the effects of water from large rivers that contribute dissolved and colored organic matter, unlike the upwelling in eastern Venezuela, due to the immense contribution of the Orinoco River and relatively from the Amazon.

\section{PHYTOPLANKTON BIOMASS}

Colombian Guajira. In situ chlorophyll estimates are scarce; most of the values mentioned are derived from satellite images. Andrade and Barton (2005) cite a maximum chlorophyll- $a$ of $3 \mathrm{mg} / \mathrm{m}^{3}$, a value comparable to that determined in situ by Corredor (1979). During the period 2002-2014, between Santa Marta and Cabo de la Vela, chlorophyll had a positive trend $(0.05 \mathrm{mg} / \mathrm{m} /$ year $)$, but from $\sim 22 \mathrm{~km}$ from the coast it decreased $(-0.01$ to $-0.05 \mathrm{mg} / \mathrm{m}^{3} /$ year), and also from Cabo de la Vela to Punta Gallinas $\left(-0.01 \mathrm{mg} / \mathrm{m}^{3} /\right.$ year), without verifying the oceanic trend (Gutiérrez-Leones et al., 2015). To the southwest of La Guajira (Tayrona Park), during the dry season (upwelling), 
costa disminuyó (-0,01 a $\left.-0,05 \mathrm{mg} / \mathrm{m}^{3} / \mathrm{año}\right)$, y también del Cabo de la Vela a Punta Gallinas $\left(-0,01 \mathrm{mg} / \mathrm{m}^{3} / \mathrm{año}\right)$, sin verificar la tendencia oceánica (Gutiérrez-Leones et al., 2015). Al suroccidente de la Guajira (parque Tayrona), durante la época seca (surgencia), la clorofila in situ varía entre 9,3 y $13,5 \mathrm{mg} / \mathrm{m}^{3}$, con valores bajos durante las lluvias, aunque el fitoplancton es más diverso. En ambos periodos, la concentración del microplancton fue mayor que el nano y picoplancton, pero el mesozooplancton fue más abundante durante la surgencia (Franco-Herrera et al., 2006). Es de considerar el posible efecto del río Magdalena. Con las isolíneas de 0,5 y $0,25 \mathrm{mg} / \mathrm{m}^{3}$, se delimitó la dirección y extensión de la pluma, la cual, en la época seca (diciembreabril), se desplaza hacia el WNW y el resto del año hacia el NNW (Cañón y Santamaría, 2003). En diciembre de 2005, las concentraciones de clorofila fueron mayores cuando los vientos tuvieron una intensidad menor, mientras que en febrero de 2006 los valores fueron menores, a pesar de los vientos intensos que favorecen la surgencia. Este desacoplamiento físico-biológico no se había documentado (Paramo et al., 2011).

En el Caribe sur (período 1998-2009), hasta $100 \mathrm{~km}$ de la costa, se estimó la concentración de clorofila derivada de fotografías (Rueda-Roa, 2012) con énfasis en la surgencia oriental $\left(63-65^{\circ} \mathrm{W}\right)$ y occidental $\left(70-73^{\circ} \mathrm{W}\right)$. En ambas áreas, durante 8-9,5 meses del año, se calcularon valores de $\geq 0,35 \mathrm{mg} / \mathrm{m}^{3}$, pero con amplia variabilidad $(0,2$ a $5,8 \mathrm{mg} / \mathrm{m}^{3}$ ). En el occidente, el promedio anual fue de $0,37 \mathrm{mg} / \mathrm{m}^{3}$ y en el oriente de $0,55 \mathrm{mg} / \mathrm{m}^{3}$. Entre tanto, en el Caribe central, el promedio fue de $0,17 \mathrm{mg} / \mathrm{m}^{3}$ y en la surgencia de la Guajira fue de $1,15 \mathrm{mg} / \mathrm{m}^{3}$. Estos valores son inferiores a los citados para otras surgencias, que tienen ámbito de 1,5 a $4,5 \mathrm{mg} / \mathrm{m}^{3}$ en California y África NW, respectivamente (Chávez y Messié, 2009).

Oriente de Venezuela. Son cuantiosas las determinaciones in situ de clorofila $a$ realizadas desde la década de 1960. Se menciona que, entre isla Margarita y la península de Araya, el promedio anual en superficie varía entre 0,25 y $1,31 \mathrm{mg} / \mathrm{m}^{3}$, a $10 \mathrm{~m}$ entre 0,08 y $1,48 \mathrm{mg} / \mathrm{m}^{3}$ y a $20 \mathrm{~m}$ entre 0,09 y $0,90 \mathrm{mg} / \mathrm{m}^{3}$ (Margalef, 1965). Aguas afuera del río Orinoco, la concentración es de $2,4 \mathrm{mg} / \mathrm{m}^{3}$ (Morris et al., 1981). En Margarita se han realizado numerosos estudios: en la costa norte tiene ámbito entre 1,55 y 5,88 con promedio anual de 2,54 mg/m $\mathrm{m}^{3}$ (Cabrera, 1987); en el suroriente se cita de 0,95 a $1,85 \mathrm{mg} / \mathrm{m}^{3}$ (Gómez y Chanut, 1993), y en la costa sur (bahía El Guamache) varía entre 0,25 y $4,5 \mathrm{mg} / \mathrm{m}^{3}$ (Pineda y Aguado, 1980). En el suroriente y el in situ chlorophyll varies between 9.3 and $13.5 \mathrm{mg} / \mathrm{m}^{3}$, with low values during the rains, although the phytoplankton is more diverse. In both periods, the concentration of microplankton was higher than nano and picoplankton, but mesozooplankton was more abundant during upwelling (Franco-Herrera et al., 2006). The possible effect of the Magdalena River must be considered. With the 0.5 and 0.25 $\mathrm{mg} / \mathrm{m}^{3}$ isolines, the direction and extension of the plume was delimited, which, in the dry season (December-April), moves towards the WNW and the rest of the year towards the NNW (Cañón and Santamaría, 2003). In December 2005, chlorophyll concentrations were higher when the winds had a lower intensity while in February 2006, the values were lower, despite the intense winds that favor upwelling. This physical-biological decoupling had not been documented (Paramo et al., 2011).

In the southern Caribbean (period 1998-2009), up to $100 \mathrm{~km}$ from the coast, the concentration of chlorophyll derived from photographs (Rueda-Roa, 2012) was estimated with emphasis on the eastern upwelling $\left(63-65^{\circ} \mathrm{W}\right)$ and western $\left(70-73^{\circ} \mathrm{W}\right)$. In both areas, during 8-9.5 months of the year, values of $\geq 0.35 \mathrm{mg} / \mathrm{m}^{3}$ were calculated, but with wide variability $\left(0.2\right.$ to $\left.5.8 \mathrm{mg} / \mathrm{m}^{3}\right)$. In the west, the annual average was $0.37 \mathrm{mg} / \mathrm{m}^{3}$ and in the east, $0.55 \mathrm{mg} / \mathrm{m}^{3}$. Meanwhile, in the central Caribbean, the average was $0.17 \mathrm{mg} / \mathrm{m}^{3}$ and in the Guajira upwelling it was $1.15 \mathrm{mg} / \mathrm{m}^{3}$. These values are lower than those cited for other upwellings, which range from 1.5 to $4.5 \mathrm{mg} / \mathrm{m}^{3}$ in California and NW Africa, respectively (Chávez and Messié, 2009).

Eastern Venezuela. The in situ determinations of chlorophyll carried out since the 1960s are numerous. It is mentioned that, between Margarita Island and the Araya Peninsula, the annual average in surface varies between 0.25 and $1.31 \mathrm{mg} / \mathrm{m}^{3}$, at $10 \mathrm{~m}$ between 0.08 and $1.48 \mathrm{mg} / \mathrm{m}^{3}$ and at $20 \mathrm{~m}$ between 0.09 and $0.90 \mathrm{mg} / \mathrm{m}^{3}$ (Margalef, 1965). Waters outside the Orinoco River, the concentration is $2.4 \mathrm{mg} / \mathrm{m}^{3}$ (Morris et al., 1981). Numerous studies have been carried out in Margarita: on the north coast it ranges between 1.55 and 5.88 with an annual average of $2.54 \mathrm{mg} / \mathrm{m}^{3}$ (Cabrera, 1987); in the southeast, 0.95 to $1.85 \mathrm{mg} / \mathrm{m}^{3}$ is cited (Gómez and Chanut, 1993), and on the south coast (El Guamache bay) it varies between 0.25 and $4.5 \mathrm{mg} / \mathrm{m}^{3}$ (Pineda and Aguado, 1980). In the southeast and south of Margarita, annual averages range between 1.59 and $2.98 \mathrm{mg} / \mathrm{m}^{3}$ (Gómez et al., 2008). Around Margarita, the maximum surface chlorophyll is $8 \mathrm{mg} / \mathrm{m}^{3}$ (Varela et al., 2003). On the island of Coche, the concentration is higher near the bottom $(20 \mathrm{~m})$, where there 
sur de Margarita los promedios anuales oscilan entre 1,59 y $2,98 \mathrm{mg} / \mathrm{m}^{3}$ (Gómez et al., 2008). Alrededor de Margarita los máximos de clorofila en superficie son $8 \mathrm{mg} / \mathrm{m}^{3}$ (Varela et al., 2003). En la isla de Coche la concentración es mayor en proximidades del fondo $(20 \mathrm{~m})$, donde se encuentran valores hasta de $11,1 \mathrm{mg} / \mathrm{m}^{3}$ (Gómez et al., 2008). Al suroriente de Margarita, durante las surgencias intensas de 2003 y 2004, los valores máximos $\left(14,35 \mathrm{mg} / \mathrm{m}^{3}\right)$ fueron $10-12 \mathrm{~m}$ de profundidad (Gómez, 2006) y los promedios anuales fueron comparables a los valores puntuales señalados para la región (Ballester, 1965; Margalef, 1965). En el golfo de Cariaco, se citan valores de $3,8 \mathrm{mg} / \mathrm{m}^{3}$ (Mandelli y Ferraz, 1982), de 0,11 a $8,17 \mathrm{mg} / \mathrm{m}^{3}$ (Ferraz, 1987) y de 0,08 a $9,61 \mathrm{mg} / \mathrm{m}^{3}$ (Ferraz, 1989). A su vez, se registran promedios de 0,74 y $1,64 \mathrm{mg} / \mathrm{m}^{3}$ en el golfo y la fosa de Cariaco (Moigis, 1986).

En la estación Cariaco (1995-2005) se evaluaron las propiedades bioópticas de las aguas. Los cambios temporales de penetración de la luz (zona eufótica) son causados por la concentración del fitoplancton, partículas detríticas y materia orgánica disuelta (coloreada), que tienen mayor absorción durante el periodo de surgencia (enero-mayo). Es menor la profundidad de la capa eufótica $(36,7 \pm 12,3 \mathrm{~m})$ y la clorofila $\left(>1 \mathrm{mg} / \mathrm{m}^{3}\right)$, pero ella disminuye $\left(<0,2 \mathrm{mg} / \mathrm{m}^{3}\right)$ durante las lluvias (junio-noviembre) y la zona eufótica es mayor (47,9 $\pm 13,5$ m). Además, la materia orgánica disuelta domina la absorción de la luz y causa una sobreestimación (7 a $45 \%$ ) en los valores de clorofila derivada de fotografías (Lorenzoni et al., 2011). En el oriente de la cuenca Cariaco (1995-2009), el promedio (diciembre-julio) de clorofila y la producción primaria fueron $0,50 \mathrm{mg} / \mathrm{m}^{3}$ y $1,763 \pm 994 \mathrm{mg} / \mathrm{cm}^{2} /$ día, respectivamente. En el occidente de la cuenca, la temperatura es mayor y los valores de clorofila y de producción primaria son menores (Lorenzoni et al., 2017). En el periodo 1995-2017, la producción primaria fluctuó entre 320 y $628 \mathrm{gC} \mathrm{m}$ /año (Müller-Karger et al., 2019). En el golfo de Cariaco (2014-enero 2015), la clorofila varió entre 0 y $17,5 \mathrm{mg} / \mathrm{m}^{3}$ (Calvo-Trujillo et al., 2018). Las concentraciones mencionadas y determinadas en áreas costeras del oriente de Venezuela (estados Nueva Esparta y Sucre) son marcadamente mayores que los promedios en áreas relativamente próximas. Conviene recordar que la cantidad de fitoplancton puede calificarse como baja cuando la concentración de clorofila $a$ fluctúa alrededor de $0,2 \mathrm{mg} / \mathrm{m}^{3}$ (Margalef, 1961).

Desde 2002 hasta 2018, en la plataforma continental al oriente de Margarita, se muestrearon dos estaciones permanentes (Gómez y Barceló, 2014; Gómez are values of up to $11.1 \mathrm{mg} / \mathrm{m}^{3}$ (Gómez et al., 2008). To the southeast of Margarita, during the intense upwellings of 2003 and 2004, the maximum values $014.35 \mathrm{mg} / \mathrm{m}^{3}$ ) were 10-12 m deep (Gómez, 2006) and the annual averages were comparable to the specific values indicated for the region (Ballester, 1965; Margalef, 1965). In the Gulf of Cariaco, values of $3.8 \mathrm{mg} / \mathrm{m}^{3}$ (Mandelli and Ferraz, 1982), 0.11 to $8.17 \mathrm{mg} / \mathrm{m}^{3}$ (Ferraz, 1987) and 0.08 to $9.61 \mathrm{mg} / \mathrm{m}^{3}$ (Ferraz, 1989) have been reported. In turn, averages of 0.74 and $1.64 \mathrm{mg} / \mathrm{m}^{3}$ are recorded in the Gulf and the Cariaco Trench (Moigis, 1986).

In the Cariaco station (1995-2005), the biooptical properties of the waters were evaluated. Temporary changes in light penetration (euphotic zone) are caused by the concentration of phytoplankton, detrital particles and dissolved organic matter (colored), which have greater absorption during the period of upwelling (January-May). The depth of the euphotic layer $(36.7 \pm 12.3 \mathrm{~m})$ and chlorophyll $\left(>1 \mathrm{mg} / \mathrm{m}^{3}\right)$ is less, but it decreases $\left(<0.2 \mathrm{mg} / \mathrm{m}^{3}\right)$ during the rains (June-November) and the euphotic zone is larger $(47.9 \pm 13.5 \mathrm{~m})$. Furthermore, dissolved organic matter dominates the absorption of light and causes an overestimation ( 7 to $45 \%$ ) in chlorophyll values derived from photographs (Lorenzoni et al., 2011). In the eastern Cariaco basin (1995-2009), the average (December-July) of chlorophyll and primary production were $0.50 \mathrm{mg} / \mathrm{m}^{3}$ and $1.763 \pm 994 \mathrm{mg} / \mathrm{cm}^{2} /$ day, respectively. In the western part of the basin, the temperature is higher and the chlorophyll and primary production values are lower (Lorenzoni et al., 2017). In the period $1995-2017$, the primary production fluctuated between 320 and $628 \mathrm{gC} \mathrm{m}$ /year (Müller-Karger et al., 2019). In the Gulf of Cariaco (2014-January 2015), chlorophyll varied between 0 and $17.5 \mathrm{mg} / \mathrm{m}^{3}$ (CalvoTrujillo et al., 2018). The concentrations mentioned and determined in coastal areas of eastern Venezuela (Nueva Esparta and Sucre states) are markedly higher than the averages in relatively close areas. It should be remembered that the amount of phytoplankton can be classified as low when the concentration of chlorophyll fluctuates around $0.2 \mathrm{mg} / \mathrm{m}^{3}$ (Margalef, 1961).

From 2002 to 2018, on the continental shelf east of Margarita, two permanent stations were sampled (Gómez and Barceló, 2014; Gómez et al., 2014). In the first 10 years of the study, the highest annual averages of phytoplankton biomass were 2.91 and $3.09 \mathrm{mg} / \mathrm{m}^{3}$ in 2003 and 2004 (Figure 3). During 2005-2007, these decreased to $1.19 \mathrm{mg} / \mathrm{m}^{3}$ and in 2008-2009 the lowest annual averages 
et al., 2014). En los primeros 10 años de estudio, los mayores promedios anuales de biomasa de fitoplancton fueron 2,91 y $3,09 \mathrm{mg} / \mathrm{m}^{3}$ en 2003 y 2004 (Figura 3). Durante 20052007 estos disminuyeron a $1,19 \mathrm{mg} / \mathrm{m}^{3}$ y en $2008-2009$ se determinaron los menores promedios anuales $(0,91 \mathrm{y}$ $0,59 \mathrm{mg} / \mathrm{m}^{3}$, respectivamente). En 2010-2012, el promedio anual aumentó ligeramente $\left(1,28-1,51 \mathrm{mg} / \mathrm{m}^{3}\right)$; estos valores fueron menos de la mitad de la biomasa de fitoplancton en 2003 y 2004 (Gómez et al., 2014). Así mismo, al comparar los períodos de surgencia (enero-mayo) y de relajación (juniodiciembre), los promedios más altos $\left(3,60\right.$ y $\left.3,92 \mathrm{mg} / \mathrm{m}^{3}\right)$ se determinaron en las surgencias de 2003 y 2004, pero disminuyeron más de $60 \%\left(0,68\right.$ a $\left.1,51 \mathrm{mg} / \mathrm{m}^{3}\right)$ entre 2005 y 2009. En 2010 se verificó un ligero aumento a $2,40 \mathrm{mg} / \mathrm{m}^{3}$; sin embargo, en 2011 y 2012 disminuyó nuevamente $(1,82$ y $1,44 \mathrm{mg} / \mathrm{m}^{3}$ ). Durante el periodo de relajación de 2003 y 2004 , la concentración de clorofila $\left(2,68\right.$ y $\left.2,20 \mathrm{mg} / \mathrm{m}^{3}\right)$ fue mayor en comparación con los años siguientes, lo cual denota una menor biomasa de fitoplancton durante ese último período.

Desde finales del siglo pasado, se han hecho estimados de clorofila con base en imágenes satelitales. Se cita que el Caribe sur tiene las mayores concentraciones (promedio de $0,63 \mathrm{mg} / \mathrm{m}^{3}$ ), pero con una gran variabilidad anual (Müller-Karger y Varela, 1988). Durante el periodo 1998-2009, en la surgencia del oriente de Venezuela, were determined $\left(0.91\right.$ and $0.59 \mathrm{mg} / \mathrm{m}^{3}$, respectively). In 2010-2012, the annual average increased slightly (1.28$\left.1.51 \mathrm{mg} / \mathrm{m}^{3}\right)$; these values were less than half of the phytoplankton biomass in 2003 and 2004 (Gómez et al., 2014). Likewise, when comparing the periods of upwelling (January-May) and relaxation (June-December), the highest averages $\left(3.60\right.$ and $\left.3.92 \mathrm{mg} / \mathrm{m}^{3}\right)$ were determined in the upwellings of 2003 and 2004, but they decreased more than $60 \%\left(0.68\right.$ to $\left.1.51 \mathrm{mg} / \mathrm{m}^{3}\right)$ between 2005 and 2009. In 2010 there was a slight increase to $2.40 \mathrm{mg} / \mathrm{m}^{3}$; however, in 2011 and 2012 it decreased again $\left(1.82\right.$ and $\left.1.44 \mathrm{mg} / \mathrm{m}^{3}\right)$. During the relaxation period of 2003 and 2004, the chlorophyll concentration $\left(2.68\right.$ and $2.20 \mathrm{mg} / \mathrm{m}^{3}$ ) was higher compared to the following years, which denotes a lower biomass of phytoplankton during that last period.

Since the end of the last century, estimates of chlorophyll have been made based on satellite images. The southern Caribbean is cited as having the highest concentrations (average $0.63 \mathrm{mg} / \mathrm{m}^{3}$ ), but with great annual variability (Müller-Karger and Varela, 1988). During the period 1998-2009, in the upwelling of eastern Venezuela, the biomass of phytoplankton had an annual average of $1.65 \mathrm{mg} / \mathrm{m}^{3}$, being higher than in the west $\left(1.15 \mathrm{mg} / \mathrm{m}^{3}\right)$ of the southern Caribbean (Rueda-Roa, 2012; Rueda-Roa and Müller-Karger, 2013). These figures are very low compared to the aforementioned on-site values.

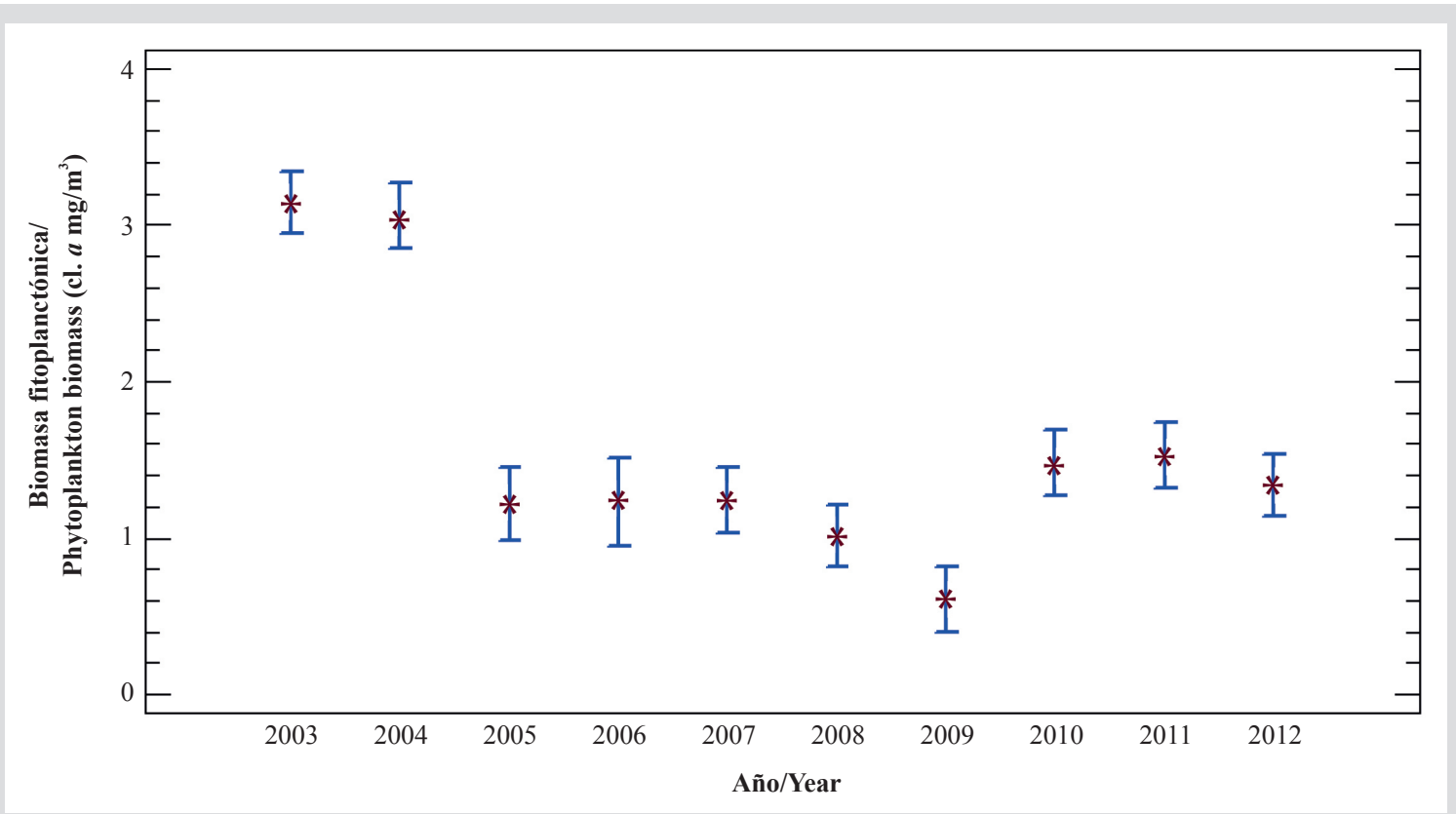

Figura 3. Variación anual de biomasa fitoplanctónica (cl. $a \mathrm{mg} / \mathrm{m}^{3}$ ) en

Figure 3. Annual variation of phytoplankton biomass (cl. $a \mathrm{mg} / \mathrm{m}^{3}$ ) columna de agua (hasta $20 \mathrm{~m}$ cada 15 días) al oriente de isla Margarita, in water column (up to $20 \mathrm{~m}$ every 15 days) east of Isla Margarita, Venezuela (década 2003-2012; Gómez y Barceló, 2014). Venezuela (decade 2003-2012; Gómez and Barceló, 2014). 
la biomasa del fitoplancton tuvo un promedio anual de $1,65 \mathrm{mg} / \mathrm{m}^{3}$, siendo mayor que en el occidente $\left(1,15 \mathrm{mg} / \mathrm{m}^{3}\right)$ del Caribe sur (Rueda-Roa, 2012; Rueda-Roa y MüllerKarger, 2013). Estas cifras son muy bajas comparadas con los valores in situ antes mencionados.

En la pluma del Orinoco, las concentraciones de clorofila in situ son menores que las calculadas a partir de imágenes (Varela et al., 2003) por causa de la materia orgánica disuelta coloreada (Müller-Karger y Aparicio, 1994; Odriozola et al., 2007). Así, entre Venezuela y Puerto Rico, en una estación localizada a $85 \mathrm{~km}$ al occidente de Granada, las imágenes sobreestiman enormemente la concentración -infieren entre $2-4 \mathrm{mg} / \mathrm{m}^{3}$ - mientras que in situ fueron $0,2 \mathrm{mg} / \mathrm{m}^{3}$ y gran proporción de la clorofila estuvo en la fracción $<2 \mu \mathrm{m}$ del fitoplancton, que se encontraba estable con respecto al agotamiento de nutrientes y con poco estrés nutricional (John et al., 2012).

En el oriente venezolano, la concentración de clorofila es 1,4 veces mayor que en el occidente del Caribe sur (Rueda-Roa, 2012), pero la biomasa estimada de los peces pelágicos es cuatro veces mayor (Stromme y Saetersdal, 1989). Por ello, debe haber otras explicaciones para la gran diferencia en la cuantía de biomasa, en especial, de especies filtradoras como la sardina. Por otra parte, no hay claridad en el asunto porque se plantea que, en el oriente de Venezuela, durante septiembre-octubre (surgencia débil), la biomasa de sardina es mayor cerca de los focos de surgencia en los primeros $10 \mathrm{~km}$ de la costa, donde se observaron valores de clorofila entre $1-3 \mathrm{mg} / \mathrm{m}^{3}$, pero en los cruceros de evaluación hidroacústica no se encuentra correlación entre la biomasa de la sardina y la temperatura y/o la clorofila in situ (Rueda-Roa, 2012). Es posible que la diferencia en la concentración de clorofila en ambas surgencias (1,4 veces) ocurra porque se consideran años posteriores a 2005 , cuando comenzó la crisis sardinera — que se mantuvo por más de una década- Durante las capturas sardineras cuantiosas de 2003 y 2004, los promedios anuales de clorofila $a$ fueron 3,09 y $2,91 \mathrm{mg} / \mathrm{m}^{3}$, y desde 2005 , cuando se inició la crisis, la biomasa de fitoplancton disminuyó notablemente (Figura 3) y se mantuvo así durante varios años (Gómez et al., 2014). También, a sotavento del área sardinera en la estación Cariaco, la concentración de clorofila y la abundancia del fitoplancton tuvieron un descenso significativo (Astor et al., 2014). En la Tabla 1 se muestran valores mencionados en superficie.

En la surgencia occidental del Caribe sur, a mediados de año, es mayor la concentración de clorofila porque se
In the Orinoco plume, in situ chlorophyll concentrations are lower than those calculated from images (Varela et al., 2003) due to the colored dissolved organic matter (Müller-Karger and Aparicio, 1994; Odriozola et al., 2007). Thus, between Venezuela and Puerto Rico, in a station located $85 \mathrm{~km}$ west of Granada, the images greatly overestimate the concentration - they infer between 2-4 $\mathrm{mg} / \mathrm{m}^{3}$ - while in situ they were $0.2 \mathrm{mg} / \mathrm{m}^{3}$ and a large proportion of chlorophyll was in the fraction $<2 \mu \mathrm{m}$ of phytoplankton, which was stable with respect to nutrient depletion and with little nutritional stress (John et al., 2012).

In eastern Venezuela, the chlorophyll concentration is 1.4 times higher than in the western southern Caribbean (Rueda-Roa, 2012), but the estimated biomass of pelagic fish is four times higher (Stromme and Saetersdal, 1989). For this reason, there must be other explanations for the large difference in the biomass amount, especially of filter species such as sardines. On the other hand, there is no clarity on the matter because it is stated that, in eastern Venezuela, during September-October (weak upwelling), the sardine biomass is higher near the upwelling sources in the first $10 \mathrm{~km}$ of the coast, where chlorophyll values between $1-3 \mathrm{mg} / \mathrm{m}^{3}$ were observed, but in the hydroacoustic evaluation cruises, no correlation was found between the biomass of the sardine and the temperature and/or chlorophyll in situ (RuedaRoa, 2012). It is possible that the difference in chlorophyll concentration in both upwellings (1.4 times) occurs because they are considered years after 2005, when the sardine crisis began - which lasted for more than a decade. During the large sardine catches of 2003 and 2004, the annual averages of chlorophyll- $a$ were 3.09 and $2.91 \mathrm{mg} / \mathrm{m}^{3}$, and since 2005, when the crisis began, the biomass of phytoplankton decreased markedly (Figure 3) and remained that way for several years (Gómez et al., 2014). Also, downwind of the sardine area in the Cariaco station, the concentration of chlorophyll and the abundance of phytoplankton had a significant decrease (Astor et al., 2014). Table 1 shows surface values mentioned.

In the western upwelling of the southern Caribbean, in the middle of the year, the chlorophyll concentration is higher because it is related to greater turbulence (RuedaRoa, 2012). However, in other upwellings, it is cited that concentrations derived from satellite images have an optimal relationship (maximum) with moderate winds and are minimum with weak or strong winds (García-Reyes and Largier, 2012). It is recognized that the chlorophyll concentrations derived from images are several times 


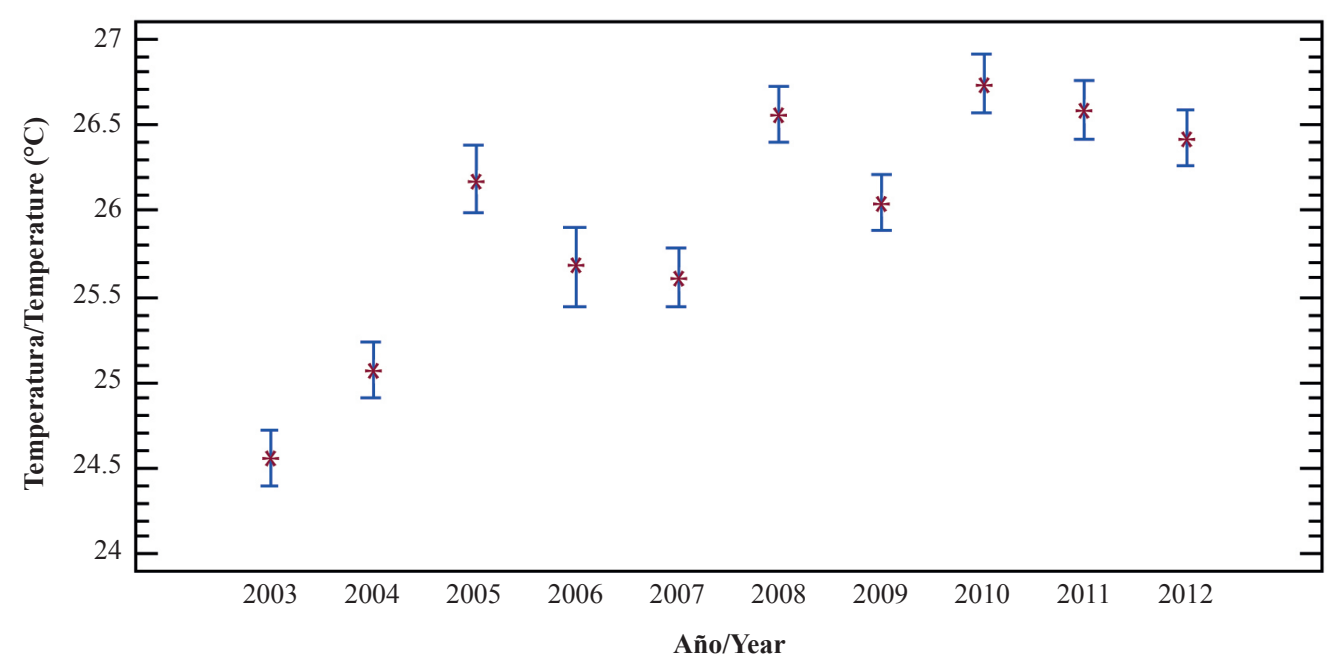

Figura 4. Variación anual de la temperatura $\left({ }^{\circ} \mathrm{C}\right)$ en la columna de agua (hasta $20 \mathrm{~m}$ cada 15 días) al oriente de la isla Margarita, Venezuela (década 2003-2012; Gómez y Barceló, 2014).
Figure 4. Annual variation of temperature $\left({ }^{\circ} \mathrm{C}\right.$ ) in the water column (up to $20 \mathrm{~m}$ every 15 days) east of Margarita Island, Venezuela (decade 20032012; Gómez and Barceló, 2014). relaciona con mayor turbulencia (Rueda-Roa, 2012). Sin embargo, en otras surgencias, se cita que las concentraciones derivadas de imágenes satelitales tienen relación óptima (máximas) con vientos moderados y son mínimas con vientos débiles o fuertes (García-Reyes y Largier, 2012). Es reconocido que las concentraciones de clorofila derivadas de imágenes sobreestiman varias veces los valores reales, en especial, cuando las concentraciones son $<5 \mathrm{mg} / \mathrm{m}^{3}$. De ahí que se estime razonable derivar algoritmos regionales, especialmente en áreas influenciadas por las descargas de ríos que afectan las propiedades ópticas de las aguas. Este es el caso del oriente de Venezuela, lo cual se explica porque los algoritmos estándar provienen de aguas oceánicas (http:// oceancolor.gsfc.nasa.gov) que ocasionan gran error y una sobreestimación entre 4 y 19 veces (Vazyulya et al., 2014). Se propone que los algoritmos regionales se determinen con base en mediciones locales y satelitales, que deben ser simultáneas y con menor error. No obstante, debe tenerse en cuenta, sin duda, que las estimaciones in situ son las reales.

Se concluye que en la Guajira colombiana son menores las concentraciones de clorofila $a$ en comparación con las determinadas al oriente de Venezuela, donde se han realizado numerosas estimaciones in situ, así como también derivadas de imágenes, que tienen también mayores concentraciones $(\sim 50 \%)$. Considerando que en ambas surgencias hay un importante recurso pesquero como la sardina, cuyos reclutas y adultos se alimentan de fitoplancton, esta especie también debería poder sostener una pesquería en la Guajira. overestimating the true values, especially when the concentrations are $<5 \mathrm{mg} / \mathrm{m}^{3}$. Hence, it is considered reasonable to derive regional algorithms, especially in areas influenced by river discharges that affect the optical properties of the waters. This is the case of eastern Venezuela, which is explained because the standard algorithms come from oceanic waters (http://oceancolor.gsfc.nasa.gov) that cause large errors and an overestimation of between 4 and 19 times (Vazyulya et al., 2014). It is proposed that regional algorithms be determined based on local and satellite measurements, which must be simultaneous and with less error. However, it should certainly be noted that the on-site estimates are the actual ones.

It is concluded that in the Colombian Guajira the concentrations of chlorophyll- $a$ are lower compared to those determined in eastern Venezuela, where numerous in situ estimates have been made, as well as those derived from images, which also have higher concentrations ( $\sim 50 \%)$. Considering that in both upwellings there is an important fishing resource such as sardines, whose recruits and adults feed on phytoplankton, that species should also be able to sustain a fishery in La Guajira.

Series of 10 years on the platform east of Margarita. Since 2002, biweekly observations at two fixed stations in the southeast of Margarita (depth reaches $35 \mathrm{~m}$ ) confirm that in the 2003 and 2004 upwellings the minimum surface temperature was $21.6{ }^{\circ} \mathrm{C}$ (Gómez, 2006; Gómez et al., 2014) and that in the water column 
Serie de 10 años sobre la plataforma al oriente de

Margarita. Desde 2002, observaciones quincenales en dos estaciones fijas en el suroriente de Margarita (profundidad alcanza $35 \mathrm{~m}$ ) constatan que en las surgencias de 2003 y 2004 la temperatura superficial mínima fue de $21,6{ }^{\circ} \mathrm{C}$ (Gómez, 2006; Gómez et al., 2014) y que en la columna de agua (hasta $20 \mathrm{~m}$ ) el promedio anual de temperatura fue de 24,5 y $25,0{ }^{\circ} \mathrm{C}$, respectivamente. Mientras tanto, en el período 2005-2012 los promedios fueron más elevados $\left(25,7\right.$ a $\left.27,0^{\circ} \mathrm{C}\right)$ y en 2010 se determinó el valor puntual máximo $\left(30,2^{\circ} \mathrm{C}\right)$. Así, durante las surgencias del período 2005-2012, los promedios de temperatura (Figura 4) y salinidad en la columna de agua indicaron que no puede adscribirse a la denominada tipo B $\left(21\right.$ a $24{ }^{\circ} \mathrm{C}$ y $>36,7$ de salinidad) de Okuda (1978, 1981), razón por la cual durante esos años no afloraron Aguas Subtropicales. En consecuencia, las surgencias fueron débiles y/o moderadas en intensidad porque no ascendió la isoterma de $21^{\circ} \mathrm{C}$, que es la indicadora de surgencia intensa, como es bien conocido (Okuda, 1978, 1981) y aceptado (Astor et al., 2003, 2004; Gómez, 2006; Gómez et al., 2008, 2012). Esto incide en la fertilidad marina y la disponibilidad de recursos pesqueros, como la sardina (Gómez et al., 2014). Entre 2005 y 2012 ocurrió un notorio incremento de la temperatura (Figura 4), situación que se había advertido desde mediados de 2005, cuando la temperatura aumentó alrededor de $2{ }^{\circ} \mathrm{C}$ al oriente de Margarita y la pesca de sardina disminuyó drásticamente (Gómez et al., 2008). En 2003 y 2004, las temperaturas promedio $\left(<25^{\circ} \mathrm{C}\right)$ fueron propicias para que hubiese una mayor abundancia de fitoplancton, lo cual efectivamente ocurrió esos años (Gómez, 2006; Cellamare y Gómez, 2007). Se cita que en los meses de la surgencia principal (eneromayo), la sardina se encuentra hasta $70 \mathrm{~km}$ de la costa, pero cuando el fenómeno se debilita (septiembre-octubre) se concentra en los primeros $10 \mathrm{~km}$ (Rueda-Roa et al., 2017).

\section{PLATAFORMA CONTINENTAL Y PRESENCIA DE ISLAS}

Guajira de Colombia. Hacia el suroccidente del Cabo de la Vela, la plataforma se ensancha y alcanza $46 \mathrm{~km}$ frente a Riohacha; luego, en Palomino vuelve a reducirse y prácticamente desaparece en el parque Tayrona y Santa Marta (Álvarez-León et al., 1995; Paramo et al., 2003). Al norte de la Guajira, frente a Punta Gallinas, la plataforma es muy estrecha: tiene $\sim 5,4 \mathrm{~km}$. La distribución de los sedimentos caracteriza tres sectores: entre ríos Buritaca y Camarones predominan arenas finas y lodos; de Riohacha (up to $20 \mathrm{~m}$ ) the annual average temperature was 24.5 and $25.0^{\circ} \mathrm{C}$, respectively. Meanwhile, in the period 2005 2012 the averages were higher $\left(25.7\right.$ to $\left.27.0^{\circ} \mathrm{C}\right)$ and in 2010 the maximum point value $\left(30.2^{\circ} \mathrm{C}\right)$ was determined. Thus, during the upwellings of the period 2005-2012, the averages of temperature (Figure 2) and salinity in the water column indicated that it cannot be ascribed to the so-called type B ( 21 to $24{ }^{\circ} \mathrm{C}$ and $>36.7$ salinity) of Okuda (1978, 1981), which is why no subtropical waters emerged during those years. Consequently, the upwellings were weak and/ or moderate in intensity because the isotherm of $21{ }^{\circ} \mathrm{C}$ did not rise, which is the indicator of intense upwelling, as is well known (Okuda, 1978, 1981) and accepted (Astor et al., 2003, 2004; Gómez, 2006; Gómez et al., 2008, 2012). This affects marine fertility and the availability of fishery resources, such as sardines (Gómez et al., 2014). Between 2005 and 2012 there was a noticeable increase in temperature (Figure 4), a situation that had been observed since mid-2005, when the temperature increased by around $2{ }^{\circ} \mathrm{C}$ east of Margarita and the sardine fishing decreased dramatically (Gómez et al., 2008). In 2003 and 2004 , the average temperatures $\left(<25^{\circ} \mathrm{C}\right)$ were conducive to a greater abundance of phytoplankton, which indeed occurred in those years (Gómez, 2006; Cellamare and Gómez, 2007). It is cited that in the months of the main upwelling (January-May), the sardine is found up to $70 \mathrm{~km}$ from the coast, but when the phenomenon weakens (September-October) it is concentrated in the first $10 \mathrm{~km}$ (Rueda-Roa et al., 2017).

\section{CONTINENTAL PLATFORM AND PRESENCE OF ISLANDS}

Colombian Guajira. Towards the southwest of Cabo de la Vela, the platform widens and reaches $46 \mathrm{~km}$ in front of Riohacha; later, in Palomino it decreases again and practically disappears in Tayrona Park and Santa Marta parks (Álvarez-León et al., 1995; Paramo et al., 2003). North of La Guajira, in front of Punta Gallinas, the shelf is very narrow: it is $\sim 5.4 \mathrm{~km}$. The distribution of the sediments characterizes three sectors: between the Buritaca and Camarones rivers, fine sand and mud predominate; from Riohacha to Cabo de la Vela, very coarse and fine sands, and from this cape to Punta Estrella, fine sand and mud again. Between Riohacha and Manaure, in the open sea sand predominates, while between Punta Espada and Punta Gallinas, at depths greater than 20-30 m, mud predominates (Paramo et al., 2012). The Guajira continental shelf has an 
al Cabo de la Vela, arenas muy gruesas y finas, y desde este cabo hasta Punta Estrella, arenas finas y lodos nuevamente. Entre Riohacha y Manaure, en mar abierto predominan las arenas. Mientras tanto, entre Punta Espada y Punta Gallinas, a profundidades mayores de 20-30 m, predominan los lodos (Paramo et al., 2012). La plataforma continental de la Guajira tiene un área de $14298 \mathrm{~km}^{2}$ entre el río Palomino $\left(11^{\circ} 25^{\prime} \mathrm{N}\right.$, $\left.73^{\circ} 57^{\prime} \mathrm{W}\right)$ y Punta Castilletes ( $\left.11^{\circ} 50^{\prime} \mathrm{N}, 71^{\circ} 18^{\prime} \mathrm{W}\right)$. Entre Arenales y el Cabo de la Vela, en fondos entre 3 y $20 \mathrm{~m}$, los "arenales" constituyen $47 \%$ del área (Chasqui et al., 2013).

Oriente de Venezuela. En dirección sur-norte abarca desde la costa continental hasta el borde de la plataforma $\left(11^{\circ} 30^{\prime} \mathrm{N}\right)$, la cual tiene una amplitud de $90 \mathrm{~km}$ y una profundidad media de $66 \mathrm{~m}$ (Herrera y Febres, 1975). Incluye el valle submarino de Carúpano, que forma parte del banco de La Tortuga, cuya longitud es de $95 \mathrm{~km}$ (Maloney, 1971). Es la plataforma venezolana más ancha, y por registros sísmicos tiene un relleno sedimentario (> $700 \mathrm{~m}$ ) que cubre un sistema subyacente de fosas y fallas tectónicas (Morelock et al., 1972); es donde la surgencia se nota con mayor intensidad. En la plataforma, el color de los sedimentos se relaciona con su contenido en carbonatos y materia orgánica: son grises o amarillentos cuando tienen un alto porcentaje de carbonato cálcico y son verdes o verde grisáceos cuando tienen abundante materia orgánica (Miró, 1974), lo que ocurre en numerosas áreas como la porción oriental de la península de Araya, el sur de las islas de Coche y Cubagua y entre el archipiélago de Los Frailes y el nororiente de Margarita, entre otras. En la plataforma, la resuspensión de células del sedimento contribuye a la mayor concentración de clorofila (Müller-Karger y Aparicio, 2004). Desde el extremo oriental de la península de Paria (punta Seca) hasta el occidente de punta Araya y la costa norte de la península de Macanao (isla Margarita), la línea de costa tiene una longitud de $\sim 400 \mathrm{~km}$. Considerando que, hasta el borde de la plataforma, su anchura media es de 90 km (Herrera y Febres, 1975), se estima que el área de la plataforma continental nororiental es de $36000 \mathrm{~km}^{2}$.

La marcada diferencia en la biomasa de peces pequeños pelágicos en las surgencias del oriente de Venezuela y de Colombia puede tener relación con la dimensión y profundidad de la plataforma continental. En el oriente venezolano, la plataforma tiene una amplitud de $90 \mathrm{~km}$ y una profundidad media de $66 \mathrm{~m}$ (Herrera y Febres, 1975). Pero en la Guajira de Colombia es angosta y profunda. Así, al norte tiene $18 \mathrm{~km}$ (profundidad $200 \mathrm{~m}$ ) y frente a Punta Gallinas 5,4 km (Paramo et al., 2012). area of $14298 \mathrm{~km}^{2}$ between the Palomino River $\left(11^{\circ} 25^{\prime} \mathrm{N}\right.$,

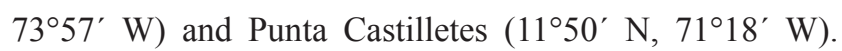
Between Arenales and Cabo de la Vela, in depths between 3 and $20 \mathrm{~m}$, the "sandbanks" constitute $47 \%$ of the area (Chasqui et al., 2013).

Eastern Venezuela. In a south-north direction, it ranges from the continental coast to the edge of the platform $\left(11^{\circ} 30^{\prime} \mathrm{N}\right)$, which has a width of $90 \mathrm{~km}$ and an average depth of $66 \mathrm{~m}$ (Herrera and Febres, 1975). It includes the underwater valley of Carúpano, which is part of the La Tortuga bank, whose length is $95 \mathrm{~km}$ (Maloney, 1971). It is the widest Venezuelan shelf, and by seismic records it has a sedimentary fill $(>700 \mathrm{~m}$ ) that covers an underlying system of trenches and tectonic faults (Morelock et al., 1972); it is where the upwelling is most noticeable. On the shelf, the color of the sediments is related to their content of carbonates and organic matter: they are gray or yellowish when they have a high percentage of calcium carbonate and they are green or grayish green when they have abundant organic matter (Miró, 1974) which occurs in numerous areas such as the eastern portion of the Araya peninsula, the south of the islands of Coche and Cubagua and between the Los Frailes archipelago and the northeast of Margarita, among others. On the platform, the resuspension of cells from the sediment contributes to the higher concentration of chlorophyll (Müller-Karger and Aparicio, 2004). From the eastern end of the Paria peninsula (Punta Seca) to the west of Punta Araya and the north coast of the Macanao peninsula (Margarita Island), the coastline is $\sim 400 \mathrm{~km}$ long. Considering that, up to the edge of the shelf, its mean width is $90 \mathrm{~km}$ (Herrera and Febres, 1975), the area of the northeastern continental shelf is estimated to be $36000 \mathrm{~km}^{2}$.

The marked difference in the biomass of small pelagic fish in the upwellings of eastern Venezuela and Colombia may be related to the size and depth of the continental shelf. In eastern Venezuela, the platform has a width of $90 \mathrm{~km}$ and an average depth of $66 \mathrm{~m}$ (Herrera and Febres, 1975). But in the Guajira of Colombia it is narrow and deep. Thus, to the north it is $18 \mathrm{~km}$ (depth $200 \mathrm{~m}$ ) and opposite Punta Gallinas it is $\sim 5.4 \mathrm{~km}$ (Paramo et al., 2012). In a wide and shallow platform, the physical properties of the upwelling control the recycling of nutrients (Arístegui et al., 2009) and favor a higher productivity of the pelagic ecosystem (Dale and Prego, 2002).

Islands. The presence of islands and archipelagos enrich the water through the well-known "island effect" 
En una plataforma amplia y poco profunda, las propiedades físicas de la surgencia controlan el reciclaje de los nutrientes (Arístegui et al., 2009) y propician una mayor productividad del ecosistema pelágico (Dale y Prego, 2002).

Islas. La presencia de islas y archipiélagos enriquecen el agua a través del conocido "efecto isla" estudiado por primera vez en Barbados - una isla próxima al Caribe suroriental-, al describir las oscilaciones verticales de aguas fértiles (Sander, 1973); en el oriente de Venezuela, se menciona en la isla La Tortuga (Margalef, 1969). Estudios de larga duración demuestran que este efecto también se relaciona con las ondas internas, que en plataformas poco profundas causan la resuspensión de sedimentos (Liao et al., 2014) y un notable incremento en la biomasa del fitoplancton $\left(\sim 1 \mathrm{mg} / \mathrm{m}^{3}\right)$, asociada con la presencia de islas, mientras que tiene $<0,1 \mathrm{mg} / \mathrm{m}^{3}$ en aguas oligotróficas próximas (Andrade et al., 2014). La plataforma nororiental venezolana se caracteriza por la presencia de islas mayores (Margarita, La Tortuga, Coche, Cubagua, entre otras), archipiélagos (Los Frailes, Los Testigos, Los Hermanos), numerosas islas menores, islotes, morros y farallones. Se estiman 167 de esos accidentes, con un área de 1404,26 km² (Gómez, 1996) y 465 km de costa (Miró, 1974). Esta situación no ocurre en el área de surgencia de la Guajira colombiana. Además, la plataforma continental tiene poca anchura y área. Se ha sugerido explorar la presencia de ondas internas en la península de la Guajira y establecer su relación con la surgencia (Gutiérrez-Leones et al., 2015).

Las islas y los archipiélagos favorecen la formación de giros, en los cuales la energía física del océano se convierte en energía trófica para sostener procesos biológicos; en su centro, los giros propician surgencia o hundimiento de agua, lo que permite la concentración o dispersión del plancton (Bakun, 2006). El movimiento de los giros facilita la conocida "triada oceánica", es decir, el enriquecimiento, la concentración y la retención de plancton para aumentar la productividad biológica y la reproducción de organismos (Bakun, 1996). Así mismo, constituyen un hábitat reproductivo para peces pelágicos costeros, como ocurre en California (Parrish et al., 1981), con la sardina brasileña (Matsuura et al., 1985) y la venezolana (Gómez, 2006). La presencia de islas propicia la acumulación de agua $\mathrm{y}$ forma bandas de flujo y otros giros en sus proximidades. En islas con 2-3 km de diámetro, las corrientes tienen una velocidad de $\geq 1 \mathrm{~m} / \mathrm{seg}$. Estas forman giros ciclónicos y anticiclónicos fuertemente divergentes que favorecen studied for the first time in Barbados - an island close to the southeastern Caribbean, when describing the vertical oscillations of fertile waters (Sander, 1973); in eastern Venezuela, it is mentioned on La Tortuga Island (Margalef, 1969). Long-term studies show that this effect is also related to internal waves, which in shallow platforms cause resuspension of sediments (Liao et al., 2014) and a notable increase in phytoplankton biomass $\left(\sim 1 \mathrm{mg} / \mathrm{m}^{3}\right)$, associated with the presence of islands, while it has $<0.1 \mathrm{mg} / \mathrm{m}^{3}$ in nearby oligotrophic waters (Andrade et al., 2014). The northeastern Venezuelan platform is characterized by the presence of larger islands (Margarita, La Tortuga, Coche, Cubagua, among others), archipelagos (Los Frailes, Los Testigos, Los Hermanos), numerous smaller islands, islets, hills and cliffs. 167 of these accidents are estimated, with an area of $\sim 1404.26 \mathrm{~km}^{2}$ (Gómez, 1996) and $465 \mathrm{~km}$ of coastline (Miró, 1974). This situation does not occur in the upwelling area of the Colombian Guajira. Furthermore, the continental shelf has little width and area. It has been suggested to explore the presence of internal waves in the Guajira peninsula and establish its relationship with the upwelling (Gutiérrez-Leones et al., 2015).

The islands and archipelagos favor the formation of gyres, in which the physical energy of the ocean is converted into trophic energy to support biological processes; in its center, the gyres favor the upwelling or subsidence of water, which allows the concentration or dispersal of plankton (Bakun, 2006). The movement of the gyres facilitates the well-known "ocean triad", that is, the enrichment, concentration and retention of plankton to increase biological productivity and the reproduction of organisms (Bakun, 1996). Likewise, they constitute a reproductive habitat for coastal pelagic fish, as occurs in California (Parrish et al., 1981) with the Brazilian (Matsuura et al., 1985) and the Venezuelan (Gómez, 2006) sardines. The presence of islands encourages the accumulation of water and forms bands of flow and other turns in their vicinity. On islands $2-3 \mathrm{~km}$ in diameter, currents have a velocity of $\geq 1 \mathrm{~m} / \mathrm{sec}$. These form strongly divergent cyclonic and anticyclonic gyres that favor the upwelling of waters in their interior, but convergences also occur in their outer limits that facilitate the formation of the triad (Bakun, 2006).

Finally, another important difference between the two upwellings is the presence of large semi-closed bodies of water in eastern Venezuela (gulfs of Cariaco and Santa $\mathrm{Fe}$ ) and of numerous coastal lagoons in the states of Nueva Esparta and Sucre. Lagoons are known to enrich the 
la surgencia de aguas en su interior, pero también en sus límites exteriores ocurren convergencias que facilitan la formación de la triada (Bakun, 2006).

Finalmente, otra diferencia importante entre ambas surgencias es la presencia de amplios cuerpos de agua semicerrados en el oriente de Venezuela (golfos de Cariaco y Santa $\mathrm{Fe}$ ) y de numerosas lagunas costeras en los estados Nueva Esparta y Sucre. Es sabido que las lagunas enriquecen las aguas del mar adyacente, pero se desconocía su función en áreas de surgencia, de por sí fértiles. Mediante estudios intensivos (cada tres días), se verificó que las aguas que salen de laguna La Restinga (isla Margarita) son más fértiles por valores mayores de producción primaria, clorofila y zooplancton, que enriquecen las aguas próximas durante el segundo semestre del año cuando en el mar adyacente sucede la relajación de la surgencia (Gómez, 1991). Este es un factor importante para que la fertilidad acuática regional ocurra durante todo el año y explica la razón por la que, hacia los meses finales del año, cardúmenes de sardina se acercan a las bocas de las lagunas para alimentarse: estas zonas se vuelven más ricas en fitoplancton que durante los primeros meses (Gómez et al., 2008). Lo anterior también explica que, en septiembre-octubre, abunden cardúmenes de sardina en los primeros $10 \mathrm{~km}$ de la costa (Rueda-Roa et al., 2017).

A diferencia de la surgencia en la Guajira colombiana, en la del nororiente de Venezuela hay una plataforma continental amplia y poco profunda, con presencia de numerosas islas y varios archipiélagos. Además, en la costa continental existen golfos, bahías y lagunas costeras que enriquecen el mar adyacente cuando la surgencia se debilita o cesa.

\section{CONCLUSIONES}

1. En la Guajira de Colombia, la surgencia parece influenciada por la contracorriente del Darién, que contiene bajas concentraciones de nutrientes inorgánicos. No hay grandes ríos que aporten materia orgánica disuelta y coloreada. La plataforma continental es poco amplia y no cuenta con archipiélagos y/o islas que favorezcan el aumento de la productividad acuática. Es posible que la elevada intensidad del viento exporte los nutrientes y el plancton hacia aguas oceánicas, lo que limita la producción pesquera.

2. El oriente de Venezuela tiene mayor fertilidad y producción pesquera porque la masa de Agua Subsuperficial Subtropical es la que abastece la surgencia durante los waters of the adjacent sea, but their role in upwelling areas, already fertile, was unknown. Through intensive studies (every three days), it was verified that the waters that leave the La Restinga lagoon (Margarita Island) are more fertile due to higher values of primary production, chlorophyll and zooplankton, which enrich the nearby waters during the second half of the year when in the adjacent sea the relaxation of the upwelling occurs (Gómez, 1991). This is an important factor for regional aquatic fertility to occur throughout the year and explains the reason why, towards the end of the year, schools of sardines approach the mouths of the lagoons to feed: these areas become more rich in phytoplankton than during the first months (Gómez et al., 2008). The above also explains that, in September-October, schools of sardines abound in the first $10 \mathrm{~km}$ of the coast (Rueda-Roa et al., 2017).

Unlike the upwelling in the Colombian Guajira, in the northeast of Venezuela there is a wide and shallow continental shelf, with the presence of numerous islands and several archipelagos. In addition, on the continental coast there are gulfs, bays and coastal lagoons that enrich the adjacent sea when the upwelling weakens or ceases.

\section{CONCLUSIONS}

1. In the Guajira of Colombia, the upwelling seems to be influenced by the Darien Countercurrent, which contains low concentrations of inorganic nutrients. There are no great rivers that contribute dissolved and colored organic matter. The continental shelf is not very wide and it does not have archipelagos and/or islands that favor the increase of aquatic productivity. The high intensity of the wind may export nutrients and plankton to ocean waters, limiting fish production.

2. The eastern part of Venezuela has greater fertility and fishing production because the Subtropical Subsurface Water mass is what supplies the upwelling during the first months of the year. During the second semester, as the most intense hydrographic phenomenon relaxes, the area is enriched with the contribution of dissolved and colored organic matter from the Orinoco River and planktonic biomass from coastal lagoons, gulfs and semi-closed bays. The wide and shallow depth of the continental shelf is also important, with the presence of archipelagos and major and minor islands, which cause local enrichment.

3. In the Colombian Guajira, it is suggested to carry out in situ studies of hydrography, inorganic nutrients, 
primeros meses del año. Durante el segundo semestre, al ocurrir la relajación del fenómeno hidrográfico más intenso, el área se enriquece con el aporte de materia orgánica disuelta y coloreada del río Orinoco y biomasa planctónica de lagunas costeras, golfos y bahías semicerradas. También tiene importancia la amplitud y poca profundidad de la plataforma continental, con la presencia de archipiélagos e islas mayores y menores, que ocasionan enriquecimientos locales.

3. En la Guajira colombiana, se sugiere realizar estudios in situ de la hidrografía, los nutrientes inorgánicos, la abundancia de fito y zooplancton y ondas internas que permitan la apropiada comprensión de la surgencia en el tiempo.

\section{AGRADECIMIENTOS}

Al Dr. Carlos J. Polo por suministrar los datos pesqueros de Colombia. Al Museo Marino de Margarita por facilitar el laboratorio y la oficina al primer autor. La investigadora científica Janneth Beltrán, del Laboratorio de Servicios de Información (Labsis) del Instituto de Investigaciones Marinas y Costeras "José Benito Vives de Andréis" (Invemar), elaboró el mapa de la Figura 1. Se agradece al editor encargado y a los evaluadores por sus muy valiosas y oportunas sugerencias. Contribución 415 del Instituto de Estudios en Ciencias del Mar (Cecimar), de la Universidad Nacional de Colombia, sede Caribe. the abundance of phyto and zooplankton and internal waves that allow the proper understanding of the upwelling in time.

\section{ACKNOWLEDGEMENTS}

To Dr. Carlos Polo for supplying the fishing data from Colombia. To the Marine Museum of Margarita for providing the first author's laboratory and office. The Scientific Researcher Janneth Beltrán (Information Services Laboratory - Labsis - Institute for Marine and Coastal Research "José Benito Vives de Andréis" - Invemar-), prepared Figure 1. We thank the editor in charge and the evaluators for their very valuable and timely suggestions. Contribution 415 of the Institute of Studies in Marine Sciences (Cecimar), of the National University of Colombia Caribbean campus.

\section{BIBLIOGRAFÍA/LITERATURE CITED}

Aguirre, R. and O. Salmerón. 2015. Characterization of the western Caribbean Sea waters through in vivo chlorophyll fluorescence. Rev. Mar. Cost., 7: 9-26.

Alonso, J., E. Blázquez, E. Isaza-Toro, and J. Vidal. 2015. Internal structure of the upwelling events at Punta Gallinas (Colombian Caribbean) from modis-sst imagery. Cont. Shelf Res., 109: 127-134.

Álvarez-León, R., J. Aguilera, C. Andrade y P. Nowak. 1995. Caracterización general de la surgencia en la Guajira colombiana. Rev. Acad. Colomb. Cienc., 29(75): 679-694.

Andrade, C. 1993. Análisis de la velocidad del viento sobre el mar Caribe. Bol. Cient. CIOH, 13: 33-44.

Andrade, C. 2001. Las corrientes superficiales en la cuenca de Colombia observadas con boyas de deriva. Rev. Acad. Colomb. Cienc., 25(96): 321-335

Andrade, C. and E. Barton. 2005. The Guajira upwelling system. Cont. Shelf Res., 25(9): 1003-1022.

Andrade, C. y E. Barton. 2013. Sobre la existencia de una celda de circulación atmosférica sobre el Caribe y su efecto en las corrientes de Ekman del Caribe suroccidental. Bol. Cient. CIOH, 31: 73-94.

Andrade, C. e Y. Thomas. 1988. Sedimentos en suspensión e hidrodinámica al sureste del delta del río Magdalena, mar Caribe, Colombia. Bol. Cient. CIOH, 8: $27-34$

Andrade, C., E. Barton, and C. Mooers. 2003. Evidence for an eastward flow along the Central and South American Caribbean coast. J. Geophys. Res., 108C6- 3185. 
Andrade, I., P. Sangrá, S. Hormazábal, and M. Correa. 2014. Island mass effect in the Juan Fernández Archipelago (33 S) southeastern Pacific. Deep Sea Res. Part I, 84: 86-99.

Aparicio, R. 2003. Revisión de las características oceanográficas de la plataforma nororiental de Venezuela. 171-205. En: Freón, P. y J. Mendoza (Eds.). La sardina (Sardinella aurita): su medio ambiente y explotación en el Oriente de Venezuela. IRD Editions, París. 549 p.

Aparicio, R. y R. Contreras. 2003. Índices de surgencia costera inducida por el viento para la región nororiental de Venezuela. 207-232. En: Freón, P. y J. Mendoza (Eds.). La sardina (Sardinella aurita), su medio ambiente y explotación en el oriente de Venezuela. IRD Editions, París. 549 p.

Aristegui, J., E. Barton, X. Álvarez, A. Santos, F. Figueiras, S. Kifani, S. Hernández, E. Mason, E. Macú, and H. Demarcq. 2009. Subregional ecosystem variability in the Canary current upwelling. Prog. Oceanogr., 83: 33-48.

Astor, Y., J. Meri y F. Müller-Karger. 1998. Variabilidad estacional hidrográfica de la fosa de Cariaco. Mem. Soc. Cienc. Nat. La Salle, 158(149): 61-72.

Astor, Y., F. Müller-Karger, and M. Scranton. 2003. Seasonal and interannual variation in the hydrography of the Cariaco Basin: implications for basin ventilation. Cont. Shelf Res., 23: 125-144.

Astor, Y., F. Müller-Karger, R. Bohrer, L. Tróccoli y J. García. 2004. Variabilidad estacional e interanual del carbono inorgánico disuelto y nutrientes en la fosa de Cariaco. Mem. Soc. Cienc. Nat. La Salle, 161-162: 235-252.

Astor, Y., M. Scranton, F. Müller-Karger, Y. Bohrer, and J. García. 2005. fC02 variability at the Cariaco tropical coastal upwelling time series station. Mar. Chem., 97: 245-261.

Astor, Y., L. Guzmán, L. Troccoli, L. Lorenzoni y F. Müller-Karger. 2014. Síntesis de las tendencias de parámetros oceanográficos y ópticos en la estación serie de tiempo Cariaco (enero 1996-diciembre 2013). Mem. Fund. La Salle Cienc. Nat., 74(181-182): 81-101.

Astor, Y., L. Lorenzoni, L. Guzmán, G. Fuentes, F. Müller-Karger, R. Varela, M. Scranton, T. Taylor, and R. Thunell. 2017. Distribution and variability of the dissolved inorganic carbon system in the Cariaco Basin, Venezuela. Mar. Chem., 195: 15-26.

Bakun, A. 1973. Coastal upwelling indices west coast of North America 1946-1971. NOAA Tech. Rep. NMFS SSRF, 67, 103 p.

Bakun, A. 1990. Global climate change and intensification of coastal ocean upwelling. Science, 247: 198-201.

Bakun, A. 1996. Patterns in the ocean: Ocean processes and marine population dynamics. University of California SeaGrant, San Diego.

Bakun, A. 2006. Fronts and eddies as key structures in the habitat of marine fish larvae: opportunity, adaptive response and competitive advantage. In: Olivar, M. and J. Govoni (Eds.). Recent advances in the study of fish eggs and larvae. Sci. Mar., 70 (Suppl.2): 105-122.

Bakun, A., D. Field, A. Redondo, and S. Weeks. 2010. Greenhouse gas, upwellings favorable winds, and the future of the coastal upwelling ecosystems. Global Change Biol., 16:1213-1228.

Ballester, A. 1965. Tablas hidrográficas. En: Estudios sobre el ecosistema pelágico del N.E. de Venezuela. Mem. Soc. Cienc. Nat. La Salle, 25(70-71-72): $39-138$.

Barton, E., D. Field, and C. Roy. 2013. Canary current upwelling: More or less? Prog. Oceanogr., 116: 167-178.

Bastidas-Salamanca, M., C. Ricaurte-Villota, E. Santamaría del Ángel, A. Ordóñez-Zúñiga, M. Murcia-Riaño y D. Romero-Rodríguez. 2017. Regionalización dinámica del Caribe. 14-31. En: Ricaurte-Villota, C. y M.L. Bastidas Salamanca (Eds.). 2017. Regionalización oceanográfica: una visión dinámica del Caribe. Ser. Publ. Esp. Invemar, 14, 180 p.

Beier, E., G. Bernal, M. Ruiz-Ochoa, and E. Barton. 2017. Freshwater exchanges and surface salinity in the Colombian basin, Caribbean Sea. PLoS One, 12(8): e0182116.

Bernal, G., G. Poveda, P. Roldán y C. Andrade. 2006. Patrones de variabilidad de las temperaturas superficiales del mar en la costa Caribe colombiana. Rev. Acad. Col. Cienc., 30(115): 195-208.

Bernal, G., M. Ruiz-Ochoa y E. Beier. 2010. Variabilidad estacional e interanual océano-atmósfera en la cuenca Colombia. Cuad. Caribe, Univ. Nal. Col., 14: $49-72$.

Black, B., W. Sindeman, D. Frank, D. Griffin, D. Stahle, M. García-Reyes, R. Rykaczewski, S. Bograd, and W. Peterson. 2014. Climate change, six centuries of variability and extremes in a couple marine-terrestrial ecosystem. Science, 345(6203): 1498-1502.

Blough N., O. Zafiriou, and J. Bonilla. 1993. Optical absorption spectra of waters from the Orinoco River outflow: terrestrial input of colored organic matter to the Caribbean. J. Geophys. Res., 98(C2): 2271-2278.

Bonells, D., T. Okuda, J. Bonilla, B. Gamboa y G. Cedeño. 1990. Algunas características hidrográficas en la región circunvecina a la isla de Margarita. Bol. Inst. Oceanogr. Ven., 29(1-2): 27-41. 
Bonilla, J., W. Senior, J. Bugden, O. Zafiriou, and R. Jones. 1993. Seasonal distribution of nutrients and primary productivity on the eastern continental shelf of Venezuela as influenced by the Orinoco River. J. Geophys. Res., 98(C2): 2245-2258.

Brenes, C., R. Benavides y S. Loza. 2017. Descripción de la distribución espacial de la clorofila $a$, temperatura y salinidad en la plataforma y el talud continentales del Caribe centroamericano. Rev. Mar. Cost., 9(1): 41-59.

Bula, G. 1990. Oceanografía. 51-66. En: Caribe Colombia. Fondo José Celestino Mutis y FEN, Bogotá.

Cabrera, E. y M. Donoso. 1993. Estudio de las características oceanográficas del Caribe colombiano. Región III Zona 1. Bol. Cient. CIOH, 13: 19-32.

Cabrera, T. 1987. Análisis de las condiciones hidrográficas de bahía de Constanza, isla de Margarita, Venezuela. Contr. Cient. Centro Invest. Cient., 13: 1-33.

Calvo-Trujillo, A., K. Rincones-Reyes, J. Díaz-Ramos, B. Márquez-García, S. Subero-Pino, E. Elista-Ramírez y L. Troccoli-Ghinaglia. 2018. Distribución espacial y temporal del fitoplancton en el golfo de Cariaco, estado Sucre, Venezuela, febrero 2014-enero 2015. Bol. Inv. Mar. Cost., 47(2): 63-82.

Cañón, M. y E. Santamaría. 2003. Influencia de la pluma del río Magdalena en el Caribe colombiano. Bol. Cient. CIOH, 21: 66-84.

Cárdenas, J. 2003. Distribución y cuantificación de la biomasa íctica del mar nororiental venezolano, con énfasis especial en la sardina, determinadas por medios hidroacústicos. 401-423. En: Freón, P. y J. Mendoza (Eds.). La sardina (Sardinella aurita), su medio ambiente y explotación en el oriente de Venezuela. IRD Editions, París. 549 p.

Cárdenas, J. y A. Achury. 2002. Acústica pesquera de los recursos marinos del nororiente de Venezuela: evaluación y seguimiento espacio-temporal del stock de sardina (Sardinella aurita Valenciennes, 1847). Mem. Soc. Cienc. Nat. La Salle, 154: 39-54.

Castellanos, P., R. Varela y F. Müller-Karger. 2002. Descripción de las áreas de surgencia al sur del mar Caribe examinadas con el sensor infrarrojo AVHRR. Mem. Soc. Cienc. Nat. La Salle, 164: 55-76.

Cellamare, M. and A. Gómez. 2007. Alimentación de la sardina Sardinella aurita (Clupeidae) en el sureste de la isla de Margarita, Venezuela. Bol. Inst. Oceanogr. Ven., 46(1): 23-36.

Centurioni, L. and P. Niiler. 2003. On the surface currents of the Caribbean Sea. Geophys. Res. Lett., 30(6): 1279.

Chasqui, L., R. Nieto, A. Rodríguez y D. Gil. 2013. Ambientes marinos de la plataforma somera de La Guajira, Caribe colombiano. Bol. Inv. Mar. Cost., 42(2): 401-412.

Chávez, F. and M. Messié. 2009. A comparison of eastern limit boundary of upwelling ecosystems. Progr. Oceanogr., 83: 80-96.

Chérubin, L. and P. Richardson. 2007. Caribbean current variability and the influence of the Amazon and Orinoco freshwater plumes. Deep Sea Res. Part I. Oceanogr. Res. Pap., 54(9): 1451-1473.

Cheung, W., R. Watson, and D. Pauly. 2013. Signature of ocean warming in global fisheries catch. Nature, 497: 365-368.

Cook, K. and E. Vizy. 2010. Hydrodynamics of the Caribbean low-level jet and its relationship to precipitation. J. Clim., 23: $1477-1494$.

Correa-Ramírez, M., A. Rodríguez-Santana, C. Ricaurte-Villota, and J. Paramo. 2020. The Southern Caribbean upwelling system off Colombia: Water masses and mixing processes. Deep-Sea Res. Part I: Oceanographic Res. Papers, 155: 103145. https://doi.org/10.1016/j.dsr.2019.103145

Corredor, J. 1977. Aspects of phytoplankton dynamics in the Caribbean Sea. FAO Fish. Rep., 200: 101-114.

Corredor, J. 1979. Phytoplankton response to low level nutrient enrichment through upwelling in the Colombian Caribbean Basin. Deep Sea Res., 26A: 731-741.

Criales-Hernández, M.I., C. García y M. Wolff. 2006. Flujos de biomasa y estructura de un ecosistema de surgencia tropical en La Guajira, Caribe colombiano. Rev. Biol. Trop., 54(4): 1257-1282.

Cropper, T., E. Hanna, and G. Bigg. 2014. Spatial and temporal seasonal trends in coastal upwelling off northwest Africa, 1981-2012. Deep Sea Res. Part I, 86: 94-111.

Cury, P. and C. Roy. 1989. Optimal environmental window and pelagic fish recruitment success in upwelling areas. Can. J. Fish. Aqua. Sci., 46: 670-680.

Dale, A. and R. Prego. 2002. Physico-biogeochemical controls on benthic-pelagic coupling of nutrient fluxes and recycling in a coastal upwelling system. Mar. Ecol. Prog. Ser., 235: 15-28.

Del Rosario, J., J. Pérez, and E. Gómez. 2019. On the prediction of upwelling events at the Colombian Caribbean coasts from modis-SST imagery. Sensors, 19(13):2861.

Donoso, M. 1990. Circulación de las aguas en el mar Caribe. 345-356. VII Seminario Ciencias Tecnologías Mar, Cali.

Dueñas-Lagos, A., M. Bastidas-Salamanca y C. Ricaurte-Villota. 2017. Región 2: contracorriente. 48-61. En: Ricaurte-Villota, C. y M. Bastidas Salamanca (Eds.). Regionalización oceanográfica: una visión dinámica del Caribe. Ser. Publ. Esp. Invemar, 14, 180 p. 
Edmont, J. and F. Boyle. 1981. The chemical mass balance in the Amazon plume. I: The nutrients. Deep Sea Res., 28(11A): 1339-1374.

Fajardo, E. 1979. Surgencia costera en proximidades de la costa de la península colombiana de la Guajira. Bol. Cient. CIOH, 1:7-19.

Febres, G. 1974. Circulación de las aguas superiores de la fosa de Cariaco en abril de 1974. Bol. Inst. Oceanogr. Ven., 13(1-2): 79-86.

Ferraz, E. 1987. Productividad primaria en el golfo de Cariaco, Venezuela. Bol. Inst. Oceanogr. Ven., 26(1 y 2): 87-110.

Ferraz, E. 1989. Influencia de los factores físicos en la distribución vertical de la biomasa fitoplanctónica en el golfo de Cariaco, Venezuela. Bol. Inst. Oceanogr. Ven., $28(1$ y 2$)$ : 47-56.

Franco-Herrera, A., L. Castro, and P. Tigreros. 2006. Plankton dynamics in the south-central Caribbean Sea: Strong seasonal changes in a coastal tropical system. Caribb. J. Sci., 42(1): 24-38.

Freón, P. y J. Mendoza. 2003. La sardina (Sardinella aurita) su medio ambiente y explotación en el oriente de Venezuela: una síntesis. 25-180. En: Freón, P. y J. Mendoza (Eds). La sardina (Sardinella aurita), su medio ambiente y explotación en el oriente de Venezuela. IRD Editions, París. 549 p.

Freón, P. y L. Ans. 2003. Comparación de datos de vientos costeros con vientos marítimos y temperatura superficial del mar en el nororiente de Venezuela. 233-262. En: Freón, P. y J. Mendoza (Eds). La sardina (Sardinella aurita): su medio ambiente y explotación en el Oriente de Venezuela. IRD Editions, París. 549 p.

Freón, P., M. El Khattabi, J. Mendoza y R. Guzmán. 2003. Una estrategia reproductiva inesperada: el caso de Sardinella aurita de las costas de Venezuela y sus relaciones con la surgencia costera. 357-387. En: Freón, P. y J. Mendoza (Eds.). La sardina (Sardinella aurita), su medio ambiente y explotación en el oriente de Venezuela. IRD Editions, París. 549 p.

Fukuoka, J. 1962. Características de las condiciones hidrográficas del mar Caribe. Mem. Soc. Cienc. Nat. La Salle, 22(63): 198-205.

Fukuoka, J. 1963. Un análisis de las condiciones hidrográficas del mar Caribe (II). Mem. Soc. Cienc. Nat. La Salle, 23(64): 43-55.

Fukuoka, J. 1964. Análisis de las condiciones hidrográficas del mar Caribe (VII). De la relación de las condiciones hidrográficas cerca de la desembocadura del Orinoco. Mem. Soc. Cienc. Nat. La Salle, 24(69): 277-307.

Fukuoka, J. 1965a. Meteorología e hidrografía. En: Estudios sobre el ecosistema pelágico del N.E. de Venezuela. Mem. Soc. Cienc. Nat. La Salle, 25(7072): 9-38.

Fukuoka, J. 1965b. Coastal upwelling near Venezuela. (I). Year to year change of upwelling. Bol. Inst. Oceanogr. Ven., 4(2): 223-233.

Fukuoka, J., A. Ballester y F. Cervigón. 1963. Un análisis de las condiciones hidrográficas del mar Caribe (IV). Mem. Soc. Cienc. Nat. La Salle, 33(66): 254-264.

Gade, H. 1961. On some oceanographic observations in the southeastern Caribbean Sea and the adjacent Atlantic Ocean with special reference to the influence of the Orinoco River. Bol. Inst. Oceanogr. Ven., 1(2): 287-342.

García-Reyes, M. and J. L. Largier. 2012, Seasonality of coastal upwelling off central and northern California: New insights, including temporal and spatial variability. J. Geophys. Res., 117: C03028. doi:10.1029/2011JC007629

García-Reyes, M., W. Sydeman, S. Thompson, B. Black, R. Rykaczewski, J. Thayer, and S. Bograd. 2013. Integrated assessment of wind effects on Central California's pelagic ecosystem. Ecosystems, 16(5): 722-735.

García-Reyes, M., J. Largier, and W. Syndeman 2014. Synoptic scale upwelling indices and predictions of phyto and zooplankton populations. Prog. Oceanogr., 10: 177-188.

Gerlotto, F. y H. Ginés. 1988. Diez años de ecointegración en Edimar referida a la sardina del oriente venezolano (Sardinella aurita). Mem. Soc. Cienc. Nat. La Salle, 48(3): 311-324.

Goes, J., H. Gomes, A. Chekalyuk, E. Carpenter, J. Montoya, V. Coles, P. Yager, W. Berelson, D. Capone, R. Forester, D. Steinberg, A. Subramaniam, and M. Hafez. 2014. Influence of the Amazon River discharge on the biogeography of phytoplankton communities in the western tropical north Atlantic. Progr. Oceanogr., 120: 29-40.

Gómez, A. 1991. Interacción entre un estuario negativo (laguna de la Restinga, isla de Margarita) y el mar Caribe adyacente. Bol. Inst. Oceanogr. Ven., 30(1 у 2): 47-55.

Gómez, A. 1996. Causas de la fertilidad marina en el nororiente de Venezuela. Interciencia, 21(3): 140-146.

Gómez, A. 2001. Recursos pesqueros: Caribe. Invest. Cienc., 301: 36-38.

Gómez, A. 2006. Caracterización ecológica del caladero de pesca más importante de Venezuela (Pampatar-La Isleta, isla de Margarita). Museo Marino de Margarita, Inf. final Fondo Nal. Invest. Cient. Técn. Venezuela (FONACIT Proy. 2000001372). Min. Cienc. Tecnol., Caracas. 648 p. 
Gómez, A. 2015. Crisis de la pesca de sardina en Venezuela: abundancia de huevos de sardina Sardinella aurita en el este de isla Margarita. Once años de estudio (2002-2013) y comentarios sobre muestreo, reproducción y desarrollo. Bol. Inst. Oceanogr. Ven., 54(2): 95-108.

Gómez, A. 2018a. Análisis del manejo de la crisis de sardina Sardinella aurita en Venezuela y comentario sobre artes de pesca y estadística. Bol. Invest. Mar. Cost., 47(1): 85-106.

Gómez, A. 2018b. Crisis de la pesca de sardina en Venezuela: posible causa un cambio de régimen. Bol. Inst. Oceanogr. Ven., 57(1): 70-82.

Gómez, A. 2019. Variación a largo término (2002-2016) en la densidad y composición del mesozooplancton indica cambio de régimen en isla Margarita (Venezuela). Bol. Invest. Mar. Cost., 48(1): 65-87.

Gómez, A. y A. Barceló. 2014. Crisis de la pesca de sardina en Venezuela: hidrografía y nutrientes al este de la isla de Margarita, una década de estudio (2003-2012). Bol. Inst. Oceanogr. Ven., 53(2): 185-203.

Gómez, A. y J.P. Chanut. 1988. Variación estacional de variables ecológicas en la bahía de Charagato, isla de Cubagua, Venezuela. Mem. Soc. Cienc. Nat. La Salle, 48(Supl. 3): 73-104.

Gómez, A. y J.P. Chanut. 1993. Hidrografía, producción y abundancia planctónica al sur de la isla de Margarita, Venezuela. Bol. Inst. Oceanogr. Ven., 32(1 y 2): $27-44$.

Gómez, A. e I. Hernández. 2008. Abundancia interanual del zooplancton nocturno en la costa este de isla Margarita, Venezuela. Bol. Inst. Oceanogr. Ven., 47(2): 91-102.

Gómez, A., E. Izaguirre y O. Gómez. 2008. Ecología de caladeros, aspectos biológicos y pesca (2003-2006) de sardina Sardinella aurita (Pisces: Clupeidae) en Nueva Esparta, Venezuela. Bol. Inst. Oceanogr. Ven., 47(2): 113-128.

Gómez, A., A. Barceló y E. Mata. 2012. Condiciones hidrográficas (2007-2009) al sur de isla Margarita y península de Araya como indicio de disminución de la fertilidad regional y posible afectación del recurso sardinero venezolano. Bol. Inst. Oceanogr. Ven., 28(1-2): 35-45.

Gómez, A., E. Mata y O. Gómez. 2014. Crisis de la pesca de sardina en Venezuela: variación de la biomasa del fitoplancton en el este de Margarita, una década de estudio (2003-2012). Bol. Inst. Oceanogr. Ven., 53(1): 25-36.

Gómez, E., J. Alonso, and J. Vidal. 2017. On the outflow of Lake Maracaibo, Venezuela. Reg. Stud. Mar. Sci., 15: 31-38.

Gómez-Letona, M., A. Ramos, J. Coca, and J. Arístegui, 2017. Trends in primary production in the Canary Current upwelling system: A regional perspective comparing remote sensing models. Front. Mar. Sci., 4: 370.

Gordon, A. 1967. Circulation of the Caribbean Sea. J. Geophys. Res., 72(24): 6207-6223.

Gutiérrez-Leones, G., M. Correa-Ramírez, S. y S. Hormazábal-Fritz. 2015. Análisis de la variabilidad espacio-temporal del sistema de surgencia de La Guajira en el dominio espacio-frecuencia, empleando el MTM-SVD (Multi Taper Method Singular Value Decomposition). Bol. Cient. CIOH, 33: 87-106.

Gutiérrez-Salcedo, J. 2011. Estructura vertical del zooplancton oceánico del mar Caribe colombiano. Tesis Mg. Cienc. Biol., Univ. Nacional de Colombia, Bogotá. 124 p.

Guzmán, R. y G. Gómez. 2000. Crecimiento, mortalidad y patrón de reclutamiento de Sardinella aurita en el nororiente de Venezuela. Zootec. Trop., 18(2): 129-144.

Haug, G., K. Hughen, D. Sigman, L. Peterson, and U. Rohl. 2001. Southward migration of the intertropical convergence zone through the Holocene. Science, 293(5533):1304-1308.

Hernández, A. and T. Joyce. 2000. Water masses and circulation in the surface layer of the Caribbean at $66^{\circ} \mathrm{W}$. Geophys. Res. Let., 27: $3497-3500$.

Herrera, L. y G. Febres. 1975. Procesos de surgencia y de renovación de aguas en la fosa de Cariaco, mar Caribe. Bol. Inst. Oceanogr. Ven., 14(1): 31-44.

Higgins, A., J. Restrepo, J. Ortiz, J. Pierini, and L. Otero. 2016. Suspended sediment transport in the Magdalena River (Colombia, South America): Hydrologic regime, rating parameters and effective discharge variability. Int. J. Sed. Res., 31(1): 25-35.

Hu, C., E. Montgomery, R. Schmitt, and F. Müller-Karger. 2004. The dispersal of Amazonas and Orinoco river water in the tropical Atlantic and Caribbean Sea: observations from the space and S-Palace floats. Deep Sea Res. Part II, 51: 1151-1171.

Hulburt, E. 1966. The distribution of phytoplankton and its relationships to hydrography between southern New England and Venezuela. J. Mar. Res., 24: 67-81.

Jacobsen, T. 1929. Contribution to the hydrography of the North Atlantic, Danish "Dana” Exp. 1920-1922. Oceanography Rep., 3, Copenhague.

John, D., J. López-Díaz, A. Cabrera, N. Santiago, J. Corredor, D. Bronk, and J. Paul. 2012. A day in the life in the dynamic marine environment: how nutrients shape diel patterns of phytoplankton photosynthesis and carbon fixation gene expression in the Mississippi and Orinoco River plumes. Hydrobiologia, 679(1): 155-173. 
Jouanno J., J. Sheinbaum, B. Barnier, J. Molines, L. Debreu, and F. Lemarié. 2008. The mesoscale variability in the Caribbean Sea. Part I: Simulations and characteristics with an embedded model. Oc. Model., 23: 82-101.

Jury, M. 2018. Eastern Venezuela coastal upwelling in context of regional weather and climate variability. Reg. Stud. Mar. Sci., 18: $219-228$.

Kato, K. 1961. Oceanochemical studies on the Gulf of Cariaco. I chemical and hydrographical observations in January 1961. Bol. Inst. Oceanogr. Ven., $1(1): 49-73$.

Lewis, W. and J. Saunders. 1989. Concentration and transport of dissolved and suspended substances in the Orinoco River. Biogeochemistry, 7(3): 203-240.

Liao, G., X. Xu, C. Liang, C. Dong, B. Zhou, T. Ding, W. Huang, and D. Xu. 2014. Analysis of kinematic parameters of internal solitary waves in the northern South China Sea. Deep Sea Res. Part I, 94: 159-172.

Liñero-Arana, M., J. Pérez y O. Díaz. 2009. El (des)conocimiento de la biodiversidad del golfo de Cariaco (Venezuela): causas y futuras perspectivas. Bol. Inst. Oceanogr. Ven., 48(2): 223-227.

Ljoen, R. and L. Herrera. 1965. Some oceanographic conditions of the coastal water of eastern Venezuela. Bol. Inst. Oceanogr. Ven., 4(1): 7-50.

Lonin, S., J. Hernández, and D. Palacios. 2010. Atmospheric events disrupting coastal upwelling in the southeastern Caribbean. J. Geophys. Res. Oceans, 115(C6): 1-17.

López, R., J. López, J. Morell, J. Corredor, and C. Del Castillo. 2013. Influence of the Orinoco river on the primary production of eastern Caribbean surface waters. J. Geophys. Res. Oceans., 118(8): 4617-4632.

Lorenzoni, L., C. Hu, R. Varela, G. Arias, L. Guzmán, and F. Müller-Karger. 2011. Bio-optical characteristics of Cariaco Basin (Caribbean Sea) waters. Cont. Shelf Res., 31(6): 582-593.

Lorenzoni, L., D. Rueda, E. Montes, R. Varela, J. Rojas, L. Guzmán, Y. Astor, and F. Müller-Karger. 2017. Spatial variability in factors that control the sinking flux of organic and inorganic particles in the Cariaco Basin: a vision from space. Int. J. Rem. Sens., 38(22): 6206-6218.

Maloney, N. 1971. Continental margin off Central Venezuela: 262-266. Colloquium resources of the Caribbean Sea and adjacent areas. Unesco, Paris.

Mandelli, E. and E. Ferraz. 1982. Primary production and phytoplankton dynamics in a tropical inlet, Gulf of Cariaco, Venezuela. Inst. Rev. Hydrobiol., 67(1): 65-85.

Marengo, J., C. Nobre, J. Tomasella, M. Oyama, G. Sampaio de Oliveira, R. de Oliveira, H. Camargo, L. Alves, and I. Brown. 2008. The drought of Amazonia in 2005. J. Clim., 21(3): 495-516.

Margalef, R. 1961. Hidrografía y fitoplancton de un área marítima de la costa meridional de Puerto Rico. Inv. Pesq., 18: 33-96.

Margalef, R. 1965. Composición y distribución del fitoplancton. En: Estudios sobre el ecosistema pelágico del N.E. de Venezuela. Mem. Soc. Cienc. Nat. La Salle, 25(70-71-72): 139-206.

Margalef, R. 1969. El ecosistema pelágico del mar Caribe. Mem. Soc. Cienc. Nat. La Salle, 32: 5-31.

Matsuura, Y., J. Amaral, G. Sato y S. Tamassia. 1985. Ocorrencia de peixes pelagicos e a estructura oceanografica de região entre o Cabo de São Tome (RJ) e Cananeia (SP) em Jan-Fev/1979. Ser. Doc. Tec., PDP/SUDEPE, Brasilia, 33: 3-70.

Meade, R., J. Nordin, H. Pérez, A. Mejía, and G. Pérez. 1983. Sediment and water discharge in Río Orinoco, Venezuela and Colombia. 2nd ${ }^{\text {Interat. Symp. River }}$ Sedimentation, Nanjing, China. 1158 p

Mendoza, J. 2003. Relaciones tróficas y flujo de biomasa en la plataforma continental del oriente venezolano: importancia de la sardina Sardinella aurita. 295-327. En: Freón, P. y J. Mendoza (Eds.). La sardina (Sardinella aurita): su medio ambiente y explotación en el Oriente de Venezuela. IRD Editions, París. 549 p.

Mendoza, J. 2015. Rise and fall of Venezuela industrial and artisanal marine fisheries: 1950-2010. Fisheries Centre. The University of British Columbia. Working Paper Series \#2015-27. 15 p.

Milliman, J., J. Butenko, I. Barbot, and J. Hedberg. 1982. Deposition patterns of modern Orinoco/Amazon muds on the northern Venezuelan shelf. J. Geophys. Res., 40(3): 643-657.

Miró, M. 1974. Morfología submarina y sedimentos marinos recientes del margen continental del nororiente de Venezuela. Cuad. Azules, 14: 1-232.

Moigis, A. 1986. Variación de la producción primaria del fitoplancton en el golfo y en fosa de Cariaco, Venezuela. Bol. Inst. Oceanogr. Ven., 25(1-2): 115126.

Molina, A., A. Pelgrain, J. Suzunaga y L. Giraldo. 1996. Comportamiento de la dinámica marina en el sector costero entre Galerazamba y Cartagena. Bol. Cient. CIOH, 17: 73-78. 
Monente, J. 1990. Influencia del río Orinoco en el Caribe: materia en suspensión. Mem. Soc. Cienc. Nat. La Salle, 49-50(131-134): 347-360.

Montoya-Sánchez, R. 2019. Procesos de interacción océano-atmósfera en la zona de surgencias de la Guajira a diferentes escalas temporales. Tesis Dr. Ingeniería-Recursos Hidráulicos, Univ. Nacional de Colombia, Medellín. 170 p.

Montoya-Sánchez, R., A. Devis-Morales, G. Bernal, and G. Poveda. 2018. Seasonal and intraseasonal variability of active and quiescent upwelling events in the Guajira system, southern Caribbean Sea. Cont. Shelf Res., 171: 97-112.

Moore, W. and J. Todd. 1993. Radium isotopes in the Orinoco estuary and Eastern Caribbean Sea. J. Geophys. Res., 98 (2C): $2233-2244$.

Morell, J. and J. Corredor. 2001. Photomineralization of fluorescent dissolved organic matter in the Orinoco River plume: estimation of ammonium release. J. Geophys. Res., 106(C8): 16807-16813.

Morelock, J., N. Maloney, and W. Bryant. 1972. Structure and sediments of the continental shelf of central Venezuela. Bol. Inst. Oceanogr. Ven., 2 (2): 127-136.

Morris, M., A. Smith, and H. Glover. 1981. Products of photosynthesis in phytoplankton off the Orinoco River and the Caribbean Sea. Limnol. Oceanogr., 26(6): 1034-1044.

Müller-Karger, F. and R. Aparicio. 1994. Mesoscale process affecting phytoplankton abundance in the southern Caribbean Sea. Cont. Shelf Res., 14(2-3): 199-221.

Müller-Karger, F. y R. Varela. 1988. Variabilidad de la biomasa del fitoplancton en aguas superficiales del mar Caribe: Una perspectiva desde el espacio con el CZCS. Mem. Soc. Cienc. Nat. La Salle, 48(3): 179-201.

Müller-Karger, F. y R. Varela. 1990. Influjo del río Orinoco en el mar Caribe: observaciones con el CZCS desde el espacio. Mem. Soc. Cienc. Nat. La Salle, 49-50(131-134): 361-390.

Müller-Karger, F., C. McClain, C. Fisher, T. Esaias, and R. Varela. 1989. Pigment distribution in the Caribbean Sea: Observations from space. Progr. Oceanogr., 2: 23-64.

Müller-Karger, F., R. Varela, R. Thunell, M. Scantron, G. Taylor, J. Capelo, Y. Astor, E. Tappa, J. Akl, and H. Tung-Yuan. 2004. Características de la fosa de Cariaco y su importancia desde el punto de vista oceanográfico. Mem. Soc. Cienc. Nat. La Salle, 161-162: 215-234.

Müller-Karger, F., Y. Astor, C. Benítez-Nelson, B. Kristen, K. Fanning, L. Lorenzoni, E. Montes, D. Rueda-Roa, M. Scranton, E. Tappa, T. Gordon, G. Taylor, R. Thunell, L. Troccoli, and R. Varela. 2019. The scientific legacy of the Cariaco Ocean Time-Series Program. Ann. Rev. Mar. Sci., 11: 1.

Murcia-Riaño, M., C. Ricaurte-Villota, A. Ordóñez-Zúñiga, and M. Bastidas Salamanca. 2017. Región 1: Sistema de La Guajira: 32-47. En Ricaurte-Villota, C. y M.L. Bastidas Salamanca (Eds.). 2017. Regionalización oceanográfica: una visión dinámica del Caribe. Ser. Publ. Esp. Invemar, 14, 180 p.

Nielsen, N. 1925. Gulfströmmen. Geogr. Tiosskr., 28. Copenhague.

Odriozola, A., R. Varela, C. Hu, Y. Astor, L. Lorenzoni, and F. Müller-Karger. 2007. On the absorption of light in the Orinoco River plume. Cont. Shelf Res., 27(10-11): 1447-1464.

Oerder, V., F. Colas, V. Echevin, F. Codron, J. Tam, and A. Belmadani. 2015. Peru-Chile upwelling dynamics under climate change. J. Geophys. Res. Oceans, 120: $1152-1172$.

Okuda, T. 1978. Condiciones hidroquímicas de las aguas superficiales de la fosa de Cariaco y áreas adyacentes. FAO Fish. Rep., 200: $349-362$.

Okuda, T. 1981. Análisis hidroquímicos de la bahía de Pozuelo y sus áreas adyacentes, Venezuela. Bol. Inst. Oceanogr. Ven., 20(1 y 2): 11-22.

Okuda, T., B. Gamboa, and A. García. 1969. Seasonal variation of hydrographic conditions in the Cariaco Trench. Bol. Inst. Oceanogr. Ven., 8(1 y 2): $21-27$.

Okuda, T., J. Benítez, J. Sellier, J. Fukuoka y B. Gamboa. 1974. Revisión de los datos oceanográficos en el mar Caribe suroccidental, especialmente el margen continental de Venezuela. III Conf. Nac. Unid. Sobre Der. Mar. Cuad. Azules, 15: 3-179.

Paramo, J. y J. Viaña. 2002. Evaluación hidroacústica de machuelo (Opisthonema oglinum) y sardina (Sardinella aurita) en la zona norte del Caribe colombiano, durante julio-agosto y diciembre de 1997. Bol. Inv. Mar. Cost., 31(1): 33-52.

Paramo, J., R. Quiñones, A. Ramírez, and R. Wiff. 2003. Relationship between abundance of small pelagic fishes and environmental factors in the Colombian Caribbean Sea: an analysis based on hydroacoustic information. Aq. Liv. Res., 16(3): 239-245.

Paramo, J., M. Correa y S. Núñez. 2011. Evidencias de desacople físico-biológico en el sistema de surgencia en la Guajira, Caribe colombiano. Rev. Biol. Mar. Oceanogr., 46(3): 421-430.

Paramo, J., L. Espinoza, B. Posada, S. Núñez y S. Benavides. 2012. Distribución espacial de sedimentos en la región norte del Caribe Colombia. Bol. Inv. Mar. Cost., 41(1): 9-28. 
Pareja, L., D. Díaz, A. Rodríguez, N. Villegas e I. Pérez, 2013. Análisis del transporte y bombeo Ekman en el Caribe colombiano. Bol Cient. CIOH, 31:3-12.

Parr, A. 1937. A contribution to the hydrography of Caribbean and Cayman Seas, based upon the observations made by research ship Atlantis $1933-1934$. Bull. Bingham Oceanogr. Coll., 5(4): 1-110.

Parrish, R., C. Nelson, and A. Bakun. 1981. Transport mechanisms and reproductive success of fishes in the California Current. Biol. Oceanogr., 1: 175-203.

Pauly, D. and V. Christensen. 1995. Primary production required to sustain global fisheries. Nature, 374: 255-257.

Payne, M. 2013. Climate change at the dinner table. Nature, 497: 320-321.

Perlroth, I. 1971. Distribution of mass in the near surface waters of the Caribbean: 147-152. Symp. CICAR I. Willemstad, Curaçao. Nov. 18-26, 1968. Unesco, Paris.

Pineda, J. y A. Aguado. 1980. Variación mensual de la composición química del mejillón Perna perna (L.) cultivado y las condiciones ambientales de la bahía del Guamache, Isla de Margarita, Venezuela. Bol. Inst. Oceanogr. São Paulo, 29(2): 305-311.

Pinzón, J., A. Perdomo y J. Díaz. 1998. Isla Arena, una formación coralina saludable en el área de influencia de la pluma del río Magdalena, plataforma continental del Caribe colombiano. Bol. Inst. Inv. Mar. Cost., 27: 21-37.

Rabinovich, J. and D. Novoa. 1982. El río Orinoco y su futuro. En: Novoa, D. (Comp.). Los recursos pesqueros del río Orinoco y su explotación. Arte, Caracas.

Restrepo, J. and B. Kjerfve. 2000. Magdalena River: interannual variability (1975-1995) and revised water discharged and sediment load estimates. J. Hydrol., 235: 137-149.

Restrepo-López, J., J. Ortiz-Royero, L. Otero-Díaz y S. Ospina-Ortiz. 2015. Transporte de sedimentos en suspensión en los principales ríos del Caribe colombiano: magnitud, tendencias y variabilidad. Rev. Acad. Colomb. Cienc. Exact. Fis. Nat., 39 (153): 527-546.

Richards, F. 1960. Some chemical and hydrographic observations along the north coast of South America. I. Cabo Tres Puntas to Curaçao, including the Cariaco Trench. Deep Sea Res., 7: 163-182.

Richards, F. and R. Vaccaro. 1956. The Cariaco Trench, an anaerobic basin in the Caribbean Sea. Deep Sea Res., 3(3): 214-228.

Rodríguez, C. and R. Varela. 1987. Pigmentos clorofílicos e hidrografía en la región noroccidental de Venezuela con énfasis en el golfo de Venezuela. Ann. Inst. Invest. Mar. Punta Betín, 17: 3-14.

Rueda-Roa, D. 2012. On the spatial and temporal variability of upwelling in the southern Caribbean Sea and its influence on the ecology of phytoplankton and of Spanish sardine (Sardinella aurita). Ph. D. Thesis, Univ. South Florida. 168 p.

Rueda-Roa, D. and F. Müller-Karger. 2013. The southern Caribbean upwelling system: sea surface temperature, wind forcing and chlorophyll concentration patterns. Deep Sea Res., 78: 102-114.

Rueda-Roa, D., J. Mendoza, F. Müller-Karger, J. Cárdenas, A. Achury, and Y. Astor. 2017. Spatial variability of Spanish sardine (Sardinella aurita) abundance as related to the upwelling cycle off the southeastern Caribbean Sea. PLoS One, 12(6): e0179984.

Rueda-Roa, D., T. Ezer, and F. Müller-Karger. 2018. Description and mechanisms of the mid-year upwelling in the southern Caribbean Sea from remote sensing and local data. J. Mar. Sci. Eng., 6(2):36. https://doi.org/10.3390/jmse6020036

Ruiz-Ochoa, M. 2011. Variabilidad de la cuenca Colombia (mar Caribe) asociada con El Niño-Oscilación del Sur, vientos alisios y procesos locales. Tesis Dr. Ingeniería-Recursos Hidráulicos, Univ. Nacional de Colombia, Medellín. 202 p.

Salazar-Gómez, I., J. Díaz-Ramos, K. Rincones, L. Chazerdine, S. Subero, L. Tróccoli, B. Márquez, B. Marín, A. Márquez, and D. Hernández. 2011. Cambios diarios de la biomasa fitoplanctónica en la bahía de Mochima, Venezuela, durante la época de lluvias. Bol. Inst. Oceanogr. Ven., 50(1): 69-78.

Sander, K. 1973. Internal waves as causative mechanisms of island mass effects. Caribb. J. Sci., 13: 179-182.

Santos, F., M. Gómez-Gesteira, R. Varela, M. Ruiz-Ochoa, and J. Días. 2016. Influence of upwelling on SST trends in La Guajira system. J. Geophys. Res. Oceans, 121: 2469-2480.

Sarmiento-Devia, R., A. López-Escobar, M. Bruno, P. Dávila y A. Franco-Herrera. 2013. Variabilidad intra-anual del régimen climático en sectores de surgencia en el sudeste del mar Caribe, usando ERA Interim. Rev. Biol. Mar. Oceanogr., 48(3): 471-485.

Sheng, J. and L. Tang. 2003. A numerical study of circulation in the Western Caribbean Sea. J. Phys. Oceanogr., 33: 2049-2069.

Stromme, T. y G. Saetersdal. 1989. Prospecciones de los recursos pesqueros de las áreas de la plataforma entre Surinam y Colombia, 1988. Inf. Final. Report Surveys R/V Dr. F. Nansen. NORAD/UNDP/FAO. Inst. Mar. Res., Bergen, Noruega. 145 p.

Sydeman, W., M. García-Reyes, D. Shoeman, R. Rykaczeski, S. Thompson, B. Black, and S. Bograd. 2014. Climate change and wind intensification in coastal upwelling ecosystems. Science, 345(6192): 77-80. 
Taylor, G., F. Müller-Karger, R. Thunell, M. Scranton, Y. Astor, R. Varela, L. Troccoli, L. Lorenzoni, K. Fanning, S. Hameed, and O. Doherty, 2012. Ecosystem responses in the southern Caribbean Sea to global climate change. Proc. Natl. Acad. Sci. USA, 109(47): 19315-19320.

Van Andel, T. 1967. The Orinoco delta. J. Sed. Petrol., 37: 297-310.

Varela, R., F. Carvajal y F. Müller-Karger. 2003. El fitoplancton en la plataforma nororiental de Venezuela. 263-294. En: Freón, P. y J. Mendoza (Eds.). La sardina (Sardinella aurita), medio ambiente y explotación en el oriente de Venezuela. IRD Editions, París. 549 p.

Vazyulya, S., A. Khrapko, O. Kopelevich, V. Burennkov, T. Eremina, and A. Isaev. 2014. Regional algorithms for the estimation of chlorophyll and suspended matter concentration in the Gulf of Finland from MODIS-Aqua satellite data. Oceanologia, 56(4): 737-756.

Walsh, J., D. Dieterle, F. Müller-Karger, R. Bohrer, W. Paul, R. Varela, R. Aparicio, R. Díaz, R. Thunell, G. Taylor, M. Scranton, K. Fanning, and E. Peltzer. 1999. Simulation of carbon-nitrogen cycling during spring upwelling in the Cariaco Basin. J. Geophys. Res., 104(C4): 7807-7825.

Wang, D., T. Gouhier, B. Menge, and A. Ganguly. 2015. Intensification and spatial homogenization of coastal upwelling under climate change. Nature, 518: 390-394.

Wilson, B. y L. Hayek. 2019. Planktonic foraminifera as indicators of oceanographic complexity on the southern Caribbean Sea continental shelf. Estuar. Coastal Shelf Sci., 228: 106359.

Wüst, G. 1963. On the stratification and circulation in the cold water sphere of the Atlantic Caribbean basin. Deep Sea Res., 10(3): 165-187.

Wüst, G. 1964. Stratification and circulation in the Antillean Caribbean Basins. Part I. Columbia Univ. Press. 